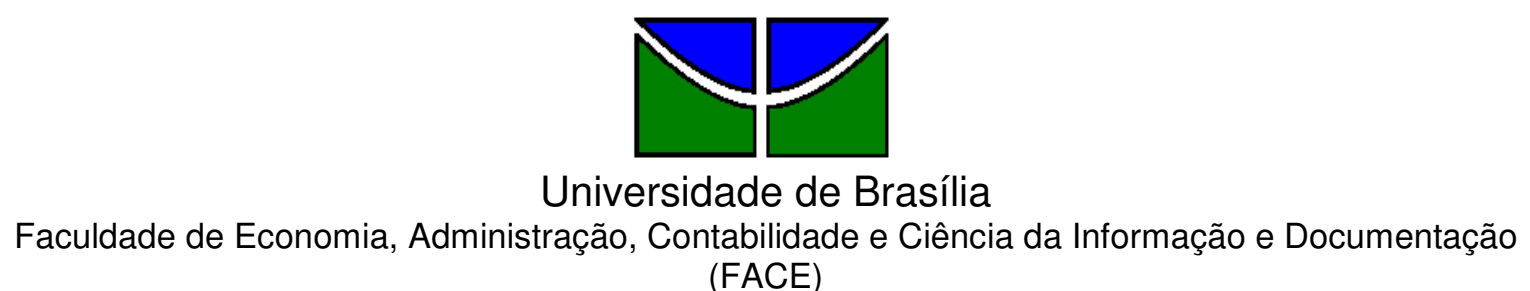

(FACE)

\author{
DEPARTAMENTO DE ADMINISTRAÇÃO
}

TRABALHO DE CONCLUSÃO DE CURSO

\title{
OS IMPACTOS DA CRISE FINANCEIRA E ECONÔMICA MUNDIAL NO ORÇAMENTO PÚBLICO FEDERAL BRASILEIRO
}

Paula Ramalho Nóbrega Sant Ana - 05/37357

Brasília - DF

Junho, 2009 


\title{
OS IMPACTOS DA CRISE FINANCEIRA E ECONÔMICA MUNDIAL NO ORÇAMENTO PÚBLICO FEDERAL BRASILEIRO.
}

\author{
Paula Ramalho Nóbrega Sant’Ana
}

Prof. Orientador:

José Matias Pereira, Dr.

Prof. Co-orientador:

Edson Ronaldo Nascimento, MSc.

"Trabalho apresentado em cumprimento às exigências para a conclusão do curso de Bacharelado em Administração e obtenção do grau de Administradora"

Brasília - DF Junho, 2009 
SANT'ANA, Paula Ramalho Nóbrega..

Os impactos da crise financeira e econômica mundial no orçamento público federal brasileiro / Paula Ramalho Nóbrega Sant'Ana - Brasília, 2009.

$111 \mathrm{f}$. : il.

Monografia (graduação) - Universidade de Brasília, Departamento de Administração, 2009.

Orientador: José Matias Pereira, Dr., Departamento de Administração.

Co-orientador: Edson Ronaldo Nascimento, MSc., Departamento de Administração.

1. Orçamento Público Federal. 2. Crise financeiro-econômica. 3. Parâmetros Macroeconômicos. 4. Políticas fiscal e Monetária. 


\title{
OS IMPACTOS DA CRISE FINANCEIRA E ECONÔMICA MUNDIAL NO ORÇAMENTO PÚBLICO FEDERAL BRASILEIRO.
}

\begin{abstract}
A Comissão Examinadora, abaixo identificada, aprova o Trabalho de Conclusão do Curso de Administração da Universidade de Brasília da aluna
\end{abstract}

\section{Paula Ramalho Nóbrega Sant'Ana}

José Matias Pereira, Dr.

Professor Orientador
Edson Ronaldo Nascimento, MSc Professor Co-orientador

Domingos Spezia, MSc.

Professor Examinador 
Este trabalho é dedicado àqueles que participaram ativamente de seu desenvolvimento: Dr. José Matias Pereira, MSc. Edson Ronaldo Nascimento, Tiago Martins Barbosa, Maíra Martins, Ismael Pamplona, Gabrielle Cobucci e meus familiares. 


\section{AGRADECIMENTOS}

Por este momento, em especial, agradeço à Universidade de Brasília, aos nobres professores e servidores pelos conhecimentos transmitidos, em especial aos professores do Estágio Supervisionado que nortearam esta pesquisa

Meu sincero agradecimento e admiração ao meu orientador, Dr. José Matias Pereira, que acreditou no meu potencial e tornou este trabalho possível, e ao meu co-orientador, professor e mestre, Edson Ronaldo Nascimento, pela seriedade, generosidade e dedicação na construção deste estudo.

Também sou grata à rica colaboração dos entrevistados: Paulo H. Feijó (Tesouro), Milko Matijascic (IPEA), Maria Liz (Senado) e Cristiano Portugal (MPOG).

Ver este trabalho pronto vai muito além de um semestre de dedicação. Ele representa o desfecho de uma grande etapa da minha vida e me remete a todo o caminho já percorrido. As dificuldades sempre existiram. Coube a mim decidir aceitálas ou superá-las

Eu decidi superar os desafios porque minha mãe, Jandina, sempre me fortaleceu. E, com muito carinho, esculpiu o meu caráter, afirmando que só por meio do conhecimento eu construiria o meu futuro com dignidade e respeito. No mesmo caminho segue meu irmão Ramiro, grande companheiro do qual tenho muito orgulho. Meu pai, Paulo, é dono do entusiasmo, incentivo e boa vontade que sempre me contagiaram. Meus avós Jaime e Pedrina são meus exemplos de vida e dedicação. Meu namorado, Tiago, o presente perfeito de Deus na minha vida. À toda a minha amada família, o meu agradecimento maior.

Igualmente agradeço às minhas amigas-irmãs, Rafa, Crioula (não basta ser amiga, tem que participar!), Thaís, Tantan, companheiras de longa data, e aos queridos amigos conquistados na UnB que espero levar para toda a vida: o quarteto fantástico (Alexandre, Thales e Gabi), Ismael, Maíra, Paty, Bárbaras, Sarinha, Cebola, Rodolfo, Vitor, Gustavo, Lucas, Flávinho, Eurico, Xyboka, Jamis, Tayse e Michelle. Vocês tornaram esses 9 semestres inesquecíveis!

Obrigada aos colegas do Serviço de Compras Internacionais pela compreensão nesta fase crucial da minha vida acadêmica e aos professores Gilmar Marques e Bento Félix pelo apoio.

Trabalho comprido e cumprido! 
Orçamentar refere-se a transformar recursos financeiros em objetivos humanos.

\section{AARON WILDAVSKY}

"Deve haver meios de promover o crescimento econômico com um pouco de justiça, apesar de sermos pobres, apesar de nos faltarem informações básicas, apesar de nenhum de nós, incluindo a mim mesmo, saber o suficiente, apesar de não podermos prever o que irá acontecer amanhã. Eu prometo elaborar pelo menos um orçamento que corresponda à realidade e que não repouse meramente na nossa capacidade de imprimir dinheiro sem valor. 'Onde há vontade, deve haver uma saída'" (Discurso imaginário do presidente de um país pobre prestes a ser deposto)

AARON WILDAVSKY e NAOMI CAIDEN 


\section{RESUMO}

A atual crise financeira e econômica que se originou na bolha de especulação imobiliária nos EUA vem se instalando de maneira progressiva nas maiores economias mundiais, provocando estragos comparados ao da Grade Depressão da década de 1930. A conjuntura alarmante vem exigindo providências dos governos no intuito de amenizar os impactos da crise e retomar o equilíbrio na economia. Com o Brasil, não é diferente. $O$ agravamento da crise financeira gerou aversão global ao risco, depreciando a taxa de câmbio e restringindo o crédito. A demanda externa reduziu-se, assim como os preços das commodities, refletindo diretamente nos setores exportadores. Internamente, a produção desaqueceu e acumulou estoques indesejados, além de mão-de-obra ociosa. As taxas de desemprego se elevaram, restringindo a renda e desgastando as expectativas dos consumidores, que passam a demandar menos, formando um ciclo de deterioração da economia. Diante deste cenário imprevisível, os Poderes Executivo e Legislativo se viram compelidos a realizar consecutivas revisões nos parâmetros macroeconômicos da proposta orçamentária para 2009 e, posteriormente, na própria Lei Orçamentária Anual e Lei de Diretrizes Orçamentárias do corrente ano, bem como cortes inéditos nas expectativas de arrecadação. Neste sentido, o orçamento público é compreendido como o termômetro da reação brasileira à crise, o plano orientador, motivando a realização desta pesquisa que teve como objetivo analisar os impactos da crise financeiro-econômica no orçamento público federal brasileiro. Diversos estudos, livros, notas técnicas, relatórios e entrevistas foram empregados na construção deste estudo o qual concluiu que o orçamento público federal não fica restrito às finanças públicas, é também uma ferramenta ativa de transformação da economia em sentido amplo.

Palavras-chave: Orçamento público federal, crise financeira e econômica, parâmetros macroeconômicos, políticas fiscal e monetária. 


\section{SUMÁRIO}

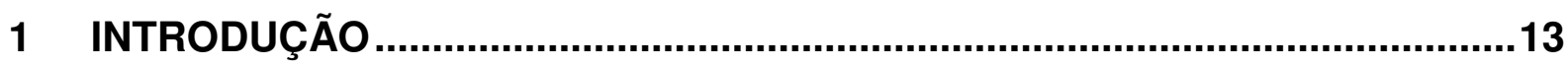

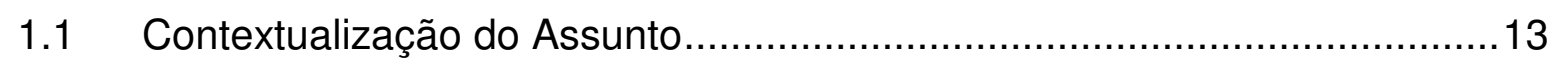

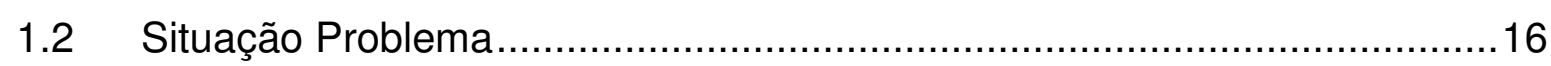

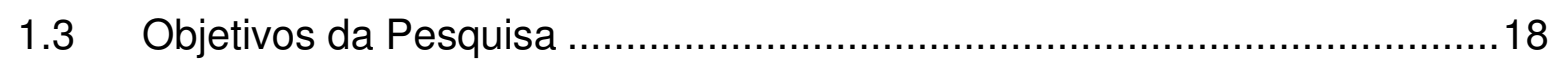

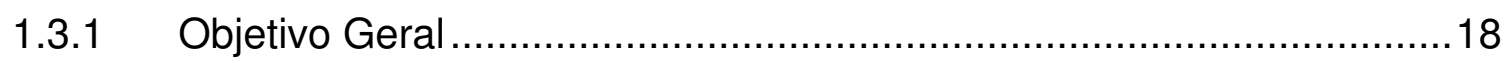

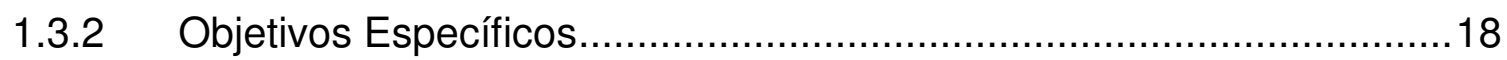

1.4 Justificativa e relevância ................................................................

1.5 Métodos e Técnicas de Pesquisa .......................................................19

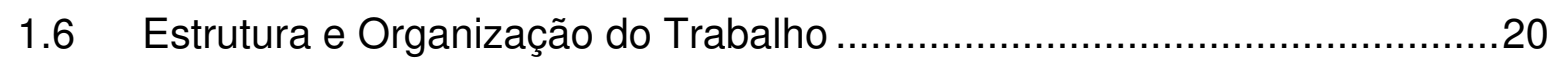

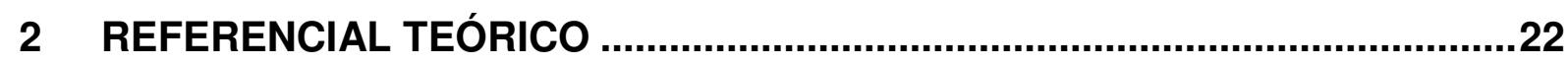

2.1 Aspectos da Teoria Neoinstitucionalista segundo Douglass North e a

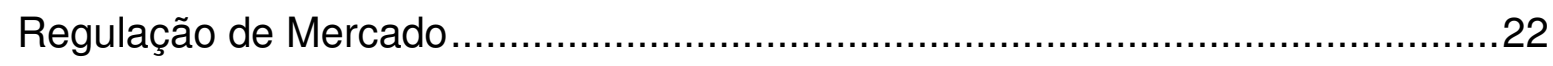

2.2 O Orçamento Público como ferramenta de Planejamento Governamental.26

2.2.1 Evolução Conceitual do Orçamento Público .......................................29

2.2.2 Orçamento Público Federal Brasileiro ...............................................31

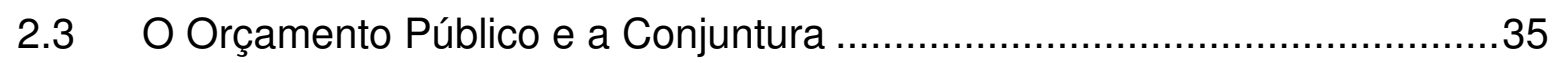

3 MÉTODOS E TÉCNICAS DE PESQUISA ....................................................37

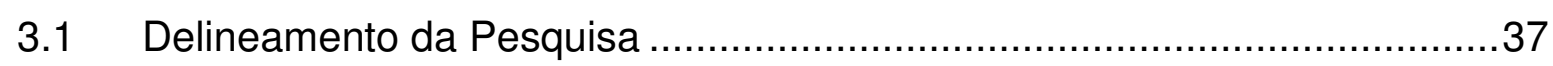

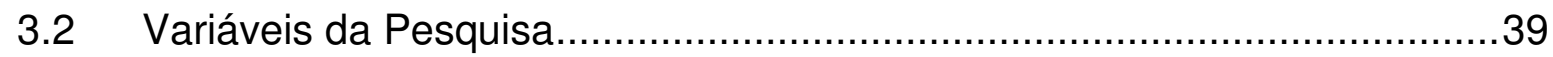

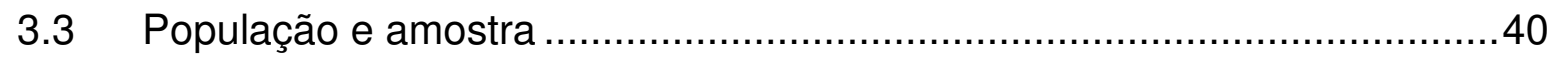

3.4 Procedimentos e instrumentos utilizados na coleta e análise do conteúdo 41

3.5 Período de realização da pesquisa ..................................................... 42

4 ANÁLISE DA INTERAÇÃO CRISE - ORÇAMENTO........................................ 43

4.1 O Contexto de Crise: Aspectos Estruturais ...............................................43

4.2 Os Impactos da Crise: Dados Macroeconômicos Brasileiros........................53

4.3 O Impacto da Crise nas Finanças e Orçamento Público Federal ................65

4.3.1 Receitas e Despesas do Governo Central ........................................67

4.3.2 Resultado Primário e Endividamento do Setor Público.........................74

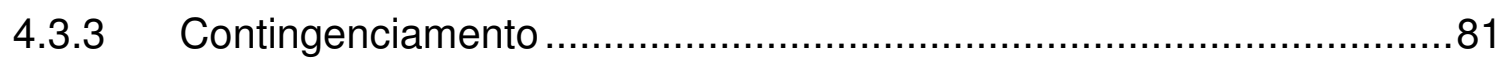

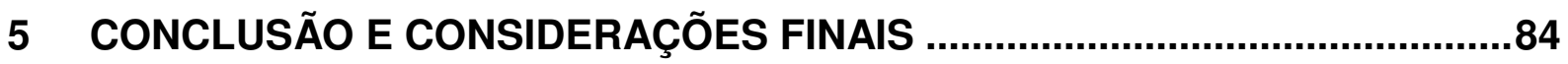

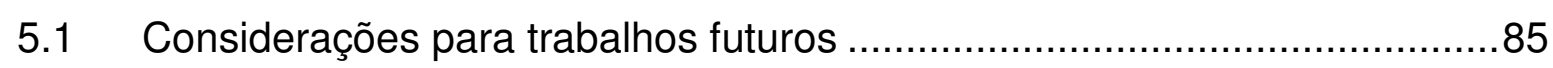

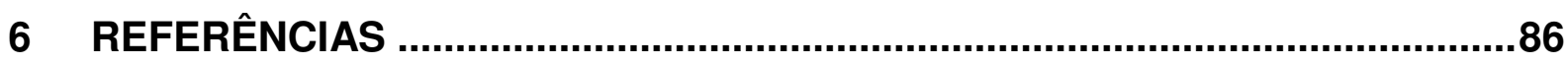




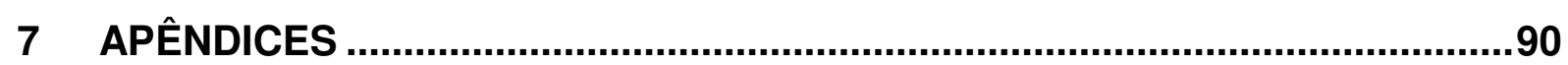

7.1 Apêndice A - Entrevista Estruturada .......................................................

7.2 Apêndice B - TERMO DE CONSENTIMENTO LIVRE E ESCLARECIDO ..91

7.3 Apêndice C - Entrevista: Cristiano Ordones Portugal - Assessor Econômico do Ministério do Orçamento, Planejamento e Gestão. .92

7.4 Apêndice D - Entrevista: Maria Liz de Medeiros Roarelli - Consultora Legislativa do Senado Federal - Área de Orçamento .95

7.5 Apêndice E - Entrevista - Paulo Henrique Feijó - Coordenador Geral de Contabilidade da Secretaria do Tesouro Nacional...........................................100 7.6 Apêndice F - Entrevista: Milko Matijascic - Chefe da Assessoria Técnica da Presidência do Instituto de Pesquisa Econômica Aplicada (IPEA) e EconomistaChefe do grupo de estudos da crise do IPEA ................................................. 104

8 ANEXOS

8.1 Anexo 01- Medidas de Desonerações Tributárias - 2009 .......................110

8.2 Anexo 02 - Contingenciamento do Decreto 6.808/09 divididos por Órgãos/Unidades Orçamentárias do Poder Executivo 


\section{LISTA DE ILUSTRAÇÕES}

Ilustração 1: Países afetados diretamente pela crise financeira e econômica.........15

Ilustração 2: Crescimento do PIB brasileiro. ................................................... 17

Ilustração 3: Ciclo Orçamentário Simplificado................................................. 33

Ilustração 4: Evolução dos Financiamentos Subprime. .......................................43

Ilustração 5: O modelo de Originação das Hipotecas Subprime.............................44

Ilustração 6: Desvalorização de Ativos Bancários ..........................................45

Ilustração 7: Comércio internacional de bens e serviços ....................................51

Ilustração 8: Taxas reais de crescimento das operações de crédito (variações dos saldos em finais de períodos entre 12 meses) ....................................................54

Ilustração 9: Evolução da taxa SELIC 2008/2009 ..............................................54

Ilustração 10: Evolução da Produção Industrial no período de jan/95 a jan/09 .......55

Ilustração 11: Saldo de Emprego 2007-2008...................................................57

Ilustração 12: Taxa de variação na ocupação - 4 maiores empregadores na média

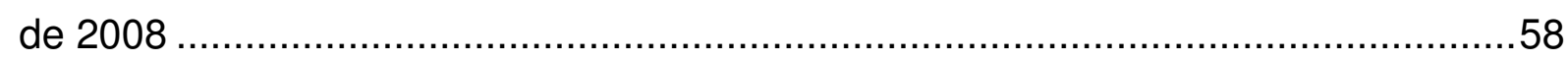

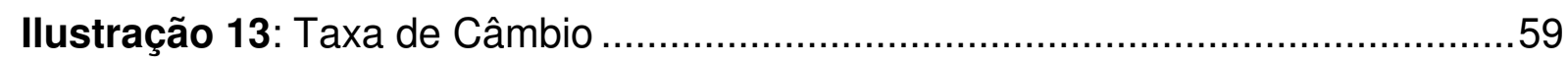

Ilustração 14 :Balança Comercial (em US\$bi) ................................................60

Ilustração 15: Evolução das expectativas de crescimento do PIB para 2009 .........63

Ilustração 16: Redução acentuada do PIB mundial (em \%) .................................64

Ilustração 17: Variação Real das Receitas Federais (em relação ao mesmo mês do

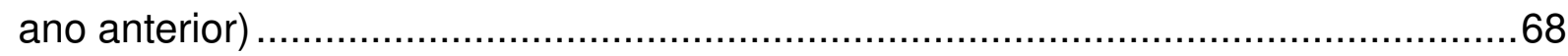

Ilustração 18: Visão Geral Orçamento 2009................................................. 72

Ilustração 19: Receitas, Despesas e Resultado do Governo Central. ......................75

Ilustração 20: Necessidade de Financiamento do Setor Público ............................78 


\section{LISTA DE TABELAS}

Tabela 1: Principais medidas adotadas por Bancos Centrais selecionados 46

Tabela 2: Crescimento real do PIB por habitante: Países desenvolvidos (\%) 50

Tabela 3: Políticas e ações de governo em países selecionados. 52

Tabela 4: PIB: taxa real de crescimento trimestral e acumulado no ano (\%) 56

Tabela 5: Crescimento do PIB 63

Tabela 6: Síntese da Proposta Orçamentária para 2009 (R \$ bilhões)... 66

Tabela 7: Receitas $2008-2009$ .69

Tabela 8: Receita Líquida Administrada pela RFB, 2008 - 2009 - Previsão e Arrecadação Jan-Abr ( $\mathrm{R} \$$ milhões) 69

Tabela 9: Despesas Primárias e resultados da União. 72

Tabela 10: Principais Parâmetros e Projeções Econômico-Fiscais, 2007-2009. 75

Tabela 11: Resultado Primário 77

Tabela 12: Dívida Pública Federal (DPF) de Responsabilidade do Tesouro Nacional em Mercado. .79

Tabela 13: Orçamentos Fiscal e da Seguridade 2009 : Determinantes do Contingenciamento de Despesas do Executivo nos Decretos de Programação Financeira. .82 


\section{INTRODUÇÃO}

\subsection{Contextualização do Assunto}

O crescimento da economia depende da forma de organização política e das estruturas sociais e institucionais de cada Estado nacional. Esse processo é contextualizado na globalização, a qual é regida pela dinâmica capitalista, possibilitando crescentes interações entre as diversas economias e a internacionalização do capital. Deve-se esperar que em um ambiente globalizado, as economias passem por ciclos econômicos cada vez mais sincronizados, especialmente quando choques relevantes atingem países desenvolvidos, que representam uma expressiva parcela da economia mundial.

Sob a ótica de Matias-Pereira (2009a), os efeitos da globalização podem beneficiar ou prejudicar alguns países, regiões, segmentos, indústrias, trabalhadores, entre outros, pois esse processo não é isento de riscos e de efeitos nocivos para aqueles que apresentam algum tipo de desvantagem nesse novo cenário mundial. No atual nível de interdependência entre os mercados, as implicações podem generalizar-se ao âmbito global, a exemplo da crise financeira e econômica que se instalou a partir setembro de 2008 de maneira progressiva em diversas economias.

Desde o século XVII são documentadas crises especulativas, com dimensões variadas. Entre 1970 e 2007 foram contabilizadas 124 crises bancárias sistêmicas, 208 crises cambiais e 63 episódios de não-pagamento de dívida soberana, de acordo com dados do IPEA (2009a). Originam-se num panorama positivo de juros baixos e crédito farto. $\mathrm{O}$ acesso facilitado ao dinheiro reduz a noção geral de risco. Tanto profissionais do mercado quanto cidadãos comuns se tornam mais propensos a investimentos ousados, em busca de lucros mais expressivos e imediatos.

Nesse cenário, surgem as "bolhas especulativas": ações, moedas, imóveis, empréstimos, entre outros, se tornam foco de investimentos e se valorizam muito além das reais possibilidades de retorno. No caso atual, a bolha (crescimento de mercados sem sustentação real) foi criada no mercado imobiliário dos Estados Unidos da América (EUA). Casas e apartamentos com preços em alta serviam de garantia para financiamentos imobiliários que ajudavam a elevar os preços. 
Enquanto o preço dos imóveis ascendia impulsionado pelo fácil acesso ao crédito, todos ganhavam: os compradores (com a casa própria valorizada), as construtoras, o mercado de trabalho, os bancos, as empresas hipotecárias (comissões), as seguradoras e, enfim, a economia como um todo, contribuindo para estimular a expansão do consumo nos EUA com repercussão direta na demanda por produtos no mercado mundial. Assim, boa parte do dinamismo da economia chinesa e da elevação do preço das principais commodities agrícolas e minerais exportados pelo Brasil podem ser associados à expansão do crédito a partir do aumento do preço dos imóveis nos EUA.

O que desencadeou a crise foi o fato de os títulos imobiliários que eram destacados como crédito certo, conhecidos como prime (títulos em que o devedor tem pretensão e capacidade de pagamento), na verdade, eram majoritariamente títulos subprime (títulos sem garantia de pagamento, com maior risco de inadimplência). Quando as taxas de juros começaram a subir para conter a valorização desenfreada do mercado imobiliário, as hipotecas referentes aos títulos subprime passaram a não ser honradas e as instituições financeiras se viram portadoras de "títulos podres". Assim, como a posição dos bancos era altamente alavancada, ou seja, os ativos eram maiores que seus patrimônios, e estes não eram recebíveis, essas instituições financeiras ficaram incapacitadas de honrar compromissos com seus credores. Foi o estopim da crise, em dezembro de 2007.

Os frutos da euforia especulativa foram a falência de bancos e seguradoras, a instabilidade da moeda, a recessão, a moratória e mais uma série de conseqüências que surgem como uma reação em cadeia. Dos Estados Unidos a crise atravessou o Atlântico e atingiu os países da União Européia, a Rússia e prossegue em sua onda avassaladora até a Índia, Japão e outros países do Oriente. No entanto, o mundo como um todo sente os efeitos diretos e indiretos da crise, quer pelo lado do consumo e da produção, quer pelo lado das movimentações e dos resultados financeiros, todos se transformaram, de alguma forma, em sócios (majoritários ou minoritários) da crise. Preocupa não somente a extensão geográfica da crise, mas, sobretudo, seus profundos impactos no sistema econômico. Com o Brasil não é diferente. 
Em geral, os economistas concordam que, comparativamente, o Brasil foi atingido com menos violência do que outros países afetados diretamente pela crise financeira, indicados na llustração 1, a seguir:

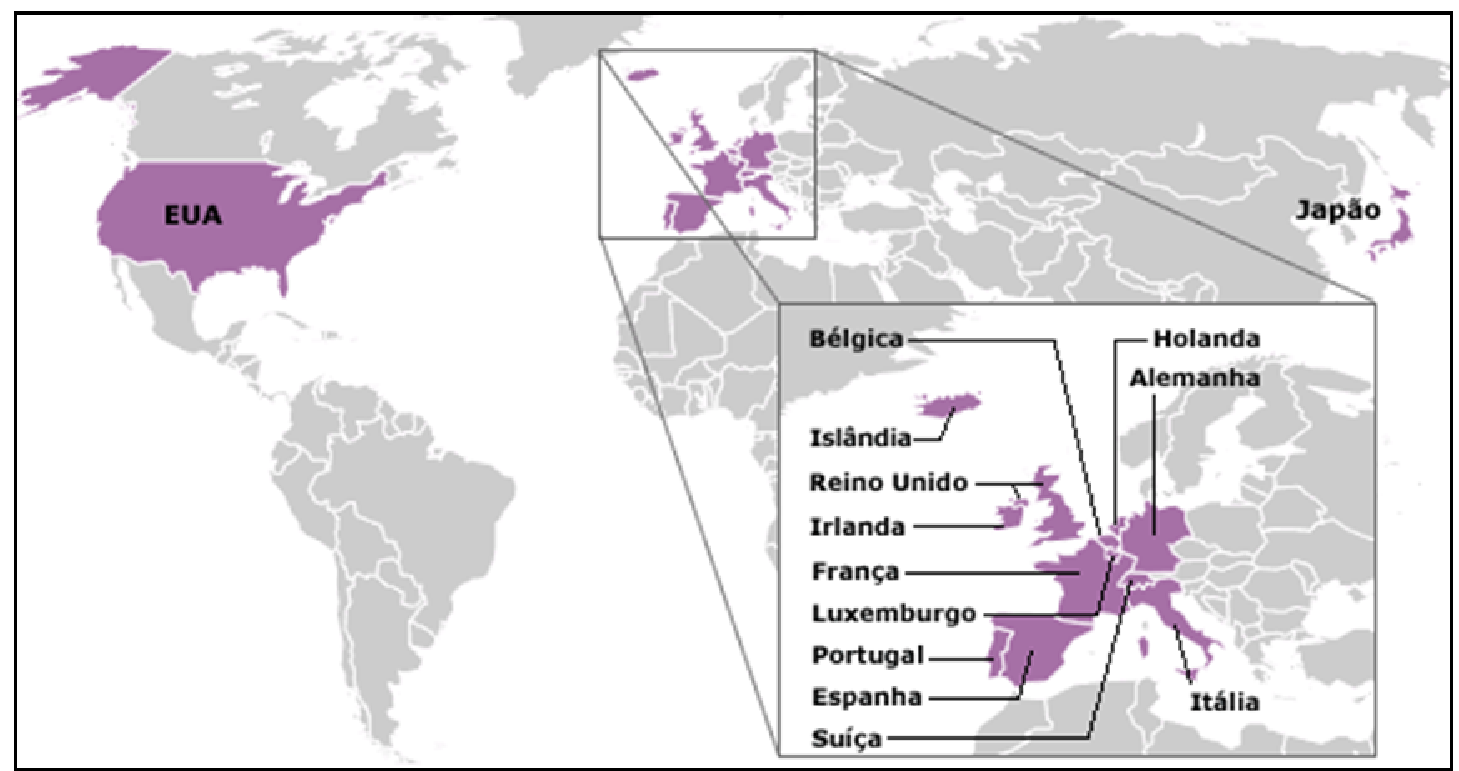

Ilustração 1: Países afetados diretamente pela crise financeira e econômica. Fonte: Folha Online de 04/11/2008. Elaboração: Folha Online.

Não obstante, de um ponto de vista não comparativo (a partir do âmbito interno), o impacto da crise na economia brasileira está sendo perturbadora. A redução de liquidez internacional causada pela crise, refletiu diretamente na diminuição e encarecimento de linhas de crédito no Brasil, essenciais aos investimentos dos setores produtivos já prejudicados com a queda da demanda internacional.

A atividade econômica começa a dar sinais de desaquecimento, causando uma série de demissões em massa e, conseqüentemente a diminuição generalizada da renda e da demanda agregada, que, por sua vez, causa prejuízo às empresas e à arrecadação tributária do Estado. Trata-se de um efeito 'bola de neve' cujos danos podem ser desastrosos e duradouros caso medidas anticíclicas não sejam adotadas prontamente.

De acordo com Baleeiro (1968), os governos não se resignam a planejar apenas a administração pública. Desejam planejar a economia e colocá-la como o centro da política, utilizando o orçamento como um meio de envolver toda a economia nacional, inclusive o setor privado. 
O contexto exposto forçou o governo brasileiro a revisar os parâmetros macroeconômicos da proposta orçamentária para 2009 durante sua tramitação no Congresso Nacional. A redução das receitas projetadas, aliadas à preocupação de agravamento dessa tendência no próximo ano, levou a Comissão Mista de Planos, Orçamentos Públicos e Fiscalização (CMO) a realizar o mais amplo corte de dotações já ocorrido na história do Congresso Nacional. Contudo, o relatório da Secretaria de Orçamento e Finanças (SOF) do Ministério do Planejamento, Orçamento e Gestão (MPOG) de março de 2009, constatou, após avaliação completa de todos os itens de receitas e despesas primárias do Governo Federal e parâmetros macroeconômicos atualizados, a queda generalizada em todos os tributos e a necessidade de limitação de empenho e movimentação financeira em $R$ \$ 21,6 bilhões em relação ao valor já revisado da Lei Orçamentária Anual (LOA) de 2009.

A reestimativa de receitas foi elaborada e aprovada no início do processo orçamentário, admitindo-se revisão no caso de mudança significativa do cenário macroeconômico ou alteração legislativa. Ambas ocorreram. Os contornos destas ações inéditas e suas conseqüências são o mote da presente pesquisa.

\subsection{Situação Problema}

Em fevereiro de 2009, o Diretor-geral da Organização Mundial do Comércio (OMC), Pascal Lamy, declarou que o mundo está passando pela pior recessão econômica desde a Segunda Guerra Mundial: o comércio está encolhendo, o crescimento está em declínio e o desemprego aumentando. Nenhum país está imune à crise. Nesses termos, o Diretor-geral da OMC resume a gravidade, a amplitude e os efeitos da crise financeira e econômica que assola o mundo (SILVA, 2009).

Surpreende a intensidade e a velocidade de propagação dos efeitos financeiros da crise sobre a economia real e a abrangência de setores afetados. No Brasil, a produção industrial apresentou uma retração de $18,7 \%$ no período compreendido entre outubro e dezembro de 2008 e o Produto Interno Bruto (PIB), no mesmo trimestre, teve retração de $3,6 \%$ em relação ao trimestre anterior, segundo séries com ajustes sazonais do IBGE (2009). 
O Projeto de Lei Orçamentária Anual (PLOA) para 2009, encaminhado pelo Poder Executivo ao Congresso Nacional em 28 de agosto de 2008, estimava um crescimento para o PIB em 2009 de 4,5\%, reduzido posteriormente para 3,5\% e revisado pelo governo, em 19 de março de 2009, para 2\%. Entretanto, em 24 de abril de 2009, o Banco Central do Brasil (BCB) apresentou em seu Relatório de Mercado - Focus, a pessimista previsão de $-0,39 \%$ de 'crescimento' para o PIB brasileiro em 2009. Este pessimismo, observado à época dessa pesquisa, devía-se ao cenário ainda incerto da economia americana: a desconfiança no sistema financeiro, à falta de reação do mercado imobiliário, ao aumento do desemprego e à queda no consumo.

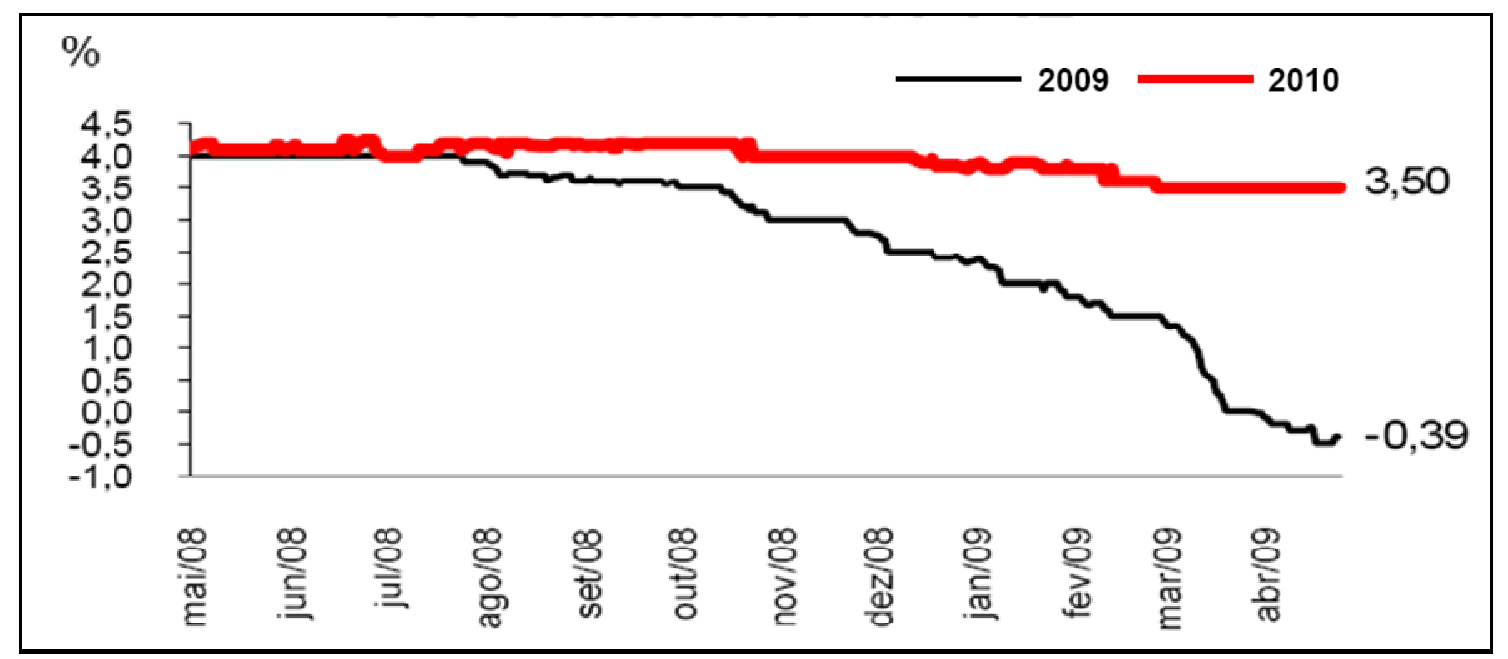

Ilustração 2: Crescimento do PIB brasileiro.

Fonte: Focus - Relatório de Mercado, BCB, em 24/04/2009.

A previsão dominante entre os economistas é a de que uma série de variáveis econômico-fiscais deverá ser alterada drasticamente, atingindo notadamente a receita pública, e eventualmente, majorando algumas despesas sociais de caráter compensatório. O prognóstico da Comissão Mista de Planos, Orçamentos Públicos e Fiscalização do Congresso Nacional (2008) é de que o superávit fiscal, possa cair substancialmente em 2009, afetando o Orçamento Público Federal brasileiro como um todo.

Em resumo, a atual conjuntura de instabilidade dos mercados financeiros e da economia externa desenha um cenário de incertezas e tensão. $O$ governo reage adotando medidas para incentivar o crescimento econômico e impedir que a crise nascida nos Estados Unidos contamine de maneira irreversível a economia brasileira. $\mathrm{O}$ orçamento público passa a ser analisado como o termômetro da reação 
brasileira, o plano orientador. Diante desses acontecimentos, o questionamento que este trabalho se propõe a responder é: quais as conseqüências esperadas da crise financeiro-econômica global para o país e seus reflexos sobre o orçamento público federal brasileiro?

\subsection{Objetivos da Pesquisa}

\subsubsection{Objetivo Geral}

- Analisar os impactos da crise financeiro-econômica no orçamento público federal brasileiro.

\subsubsection{Objetivos Específicos}

- Apresentar de forma concisa a evolução conceitual do orçamento público e seu papel como instrumento de planejamento central do governo.

- Analisar o atual colapso financeiro-econômico e seus principais reflexos no Brasil e no mundo.

- Avaliar as grandes modificações no Projeto de Lei Orçamentária Anual de 2009 e na Lei Orçamentária de 2009 (Lei no 11.897, promulgada em 30/12/2008) e nos seus parâmetros macroeconômicos em decorrência das recentes anormalidades na conjuntura financeira e econômica.

\subsection{Justificativa e relevância}

Ao estudar os impactos imediatos da crise no orçamento público da União, tem-se em mente o orçamento não apenas como uma ferramenta de planejamento dos gastos do governo, mas também como um instrumento de comunicação entre governo e sociedade, que possibilita a abertura de um diálogo no qual o governo sugere medidas para evitar prejuízos maiores no futuro e a sociedade (ou seus representantes) pondera a este respeito.

Conforme Matias-Pereira (2009a) o orçamento pode ser compreendido como um acordo especial entre o Estado e o contribuinte, sob a mediação do parlamento, visto tratar-se de um ato que materializa a origem e o montante dos recursos a 
serem obtidos (as receitas), paralelamente à natureza e montante dos dispêndios a serem efetuados (as despesas), por meio de atividades e projetos, que permitem a obtenção de objetivos e a consecução de metas firmadas nos devidos dispositivos legais. Assim, o planejamento governamental deve ser entendido como um processo contínuo de negociação entre o Estado e a sociedade.

Nesse contexto, o orçamento se afirma como instrumento de intervenção do Estado no domínio econômico, orientado para a finalidade de realizar o bem comum da sociedade.

Assim, a relevância do presente estudo está na possibilidade de seus resultados contribuírem com o entendimento dos reflexos do cenário internacional sobre o orçamento público federal brasileiro de maneira ampla, bem como a reação governamental frente aos desafios e incertezas.

A escassez de estudos relacionando as citadas variáveis é um estímulo a busca da virtuosidade nesta pesquisa, para que esta possa servir de insumo para futuros trabalhos e aprimoramentos.

É relevante enfatizar que o referido tema possui diversas limitações, principalmente ao que tange a dificuldade de avaliar a extensão e a profundidade da crise devido a sua precocidade. Sendo assim, este estudo não pretende exaurir o assunto em análise, o que seria inviável e sem propósito para um trabalho de monografia.

\subsection{Métodos e Técnicas de Pesquisa}

Apesar da escassez de trabalhos acadêmicos publicados seguindo a linha de correlação entre crise e orçamento público, há uma diversidade de estudos, notas técnicas e relatórios oficiais a esse respeito, possibilitando o acesso às informações imprescindíveis à pesquisa. $O$ desafio consiste em reunir e analisar as informações difusas quanto à crise financeiro-econômica e o orçamento público da União, ordenando-as de forma a atingir os objetivos anteriormente propostos.

O estudo, classificado como exploratório e qualitativo, é sustentado por diferentes tipos de pesquisa bibliográfica e documental. A pesquisa bibliográfica é desenvolvida a partir de material já elaborado, constituído principalmente de livros, 
jornais e revistas. A pesquisa documental se assemelha à pesquisa bibliográfica. A diferença reside na natureza das fontes: enquanto a bibliográfica conta com a contribuição de diversos autores sobre determinado assunto, a documental se traduz em materiais que ainda não receberam um tratamento analítico e podem ser manipulados de acordo com o objetivo da pesquisa. A fim de enriquecer o desenvolvimento do trabalho, serão adicionados trechos de entrevistas estruturadas com especialistas da área.

Os métodos e técnicas adotados serão esmiuçados no terceiro capítulo deste trabalho.

\subsection{Estrutura e Organização do Trabalho}

A presente pesquisa apresenta a seguinte estrutura: no primeiro capítulo é apresentada uma breve introdução para a contextualização do tema, formulação da situação problema, descrição dos objetivos do estudo, noção dos métodos e técnicas empregados e a estrutura e organização do estudo como um todo.

O segundo capítulo é dedicado à discussão do referencial teórico adotado e constitui-se de aspectos da Teoria Neoinstitucionalista segundo Douglass North e a regulação de mercado; seguida da evolução histórica das abordagens do orçamento público até o estágio atual, onde é compreendido como ferramenta de planejamento do governo e a organização básica do orçamento público brasileiro; por fim, breve abordagem sobre a conjuntura e o orçamento.

No terceiro capítulo, são apresentados detalhadamente os métodos e técnicas de pesquisa utilizados para a construção deste estudo.

O quarto capítulo é dividido em três subseções: a primeira analisa os aspectos estruturais da crise; a segunda, apresenta e compara dados macroeconômicos brasileiros e os impactos da crise; por derradeiro, avalia-se o impacto da crise nas finanças públicas e no orçamento público federal da União.

Para concluir, o quinto capítulo apresenta as idéias finais construídas após análise dos capítulos anteriores, bem como sugestões para trabalhos futuros acerca da temática. 
Por fim, serão apresentadas as referências bibliográficas consultadas para a execução da pesquisa, além de anexos e apêndices. 


\section{REFERENCIAL TEÓRICO}

Nessa parte será apresentada uma revisão da literatura que envolve a abordagem Neoinstitucionalista em Douglass North (1990), passando pelo estudo e evolução do orçamento público em nível mundial como instrumento de política fiscal (WILDAVSKY, 1992) e o orçamento público brasileiro, além de abordagens contemporâneas do papel do setor público na economia (MATIAS-PEREIRA, 2009).

\subsection{Aspectos da Teoria Neoinstitucionalista segundo Douglass North e a Regulação de Mercado}

A influência de variáveis institucionais sobre o desempenho econômico vem sendo investigada em diversos trabalhos e pesquisas recentes, destacando-se a Teoria do Neoinstitucionalismo (ou Nova Economia Institucional). A teoria aplicada ao estudo das instituições, focalizando uma análise macroeconômica tem como principal expoente Douglass North, agraciado com o Prêmio Nobel em 1993. Para o autor, estudar o desenvolvimento econômico significa estudar o desenvolvimento institucional, ou seja, demonstrar como o crescimento de longo prazo e a evolução histórica das sociedades são condicionados pela formação e evolução de suas instituições, "humanly devised constraints that shape human interaction" (North 1990, p. 3).

Segundo North (1990), as instituições são definidas como regras formais (constituições, leis, regras) e informais (convenções, normas de comportamento, códigos de conduta), idealizadas pela sociedade, a fim de criar ordem e reduzir as incertezas. Assim, instituições e organizações, respectivamente - as regras do jogo e a divisão de tarefas entre os agentes participantes - afetam o desempenho da economia na medida em que, ao dar forma e estruturar as interações humanas, reduzem incertezas e induzem a cooperação, diminuindo os custos das transações. (NORTH,1990 apud MATIAS-PEREIRA, 2009a, p.141).

A relação entre os indivíduos, ou agentes, é complexa podendo gerar inúmeros custos. Custos transacionais elevados podem dificultar ou até impedir as relações econômicas, políticas e sociais entre os indivíduos. No entendimento de North (1990), os custos transacionais originam-se do reconhecimento de que as 
imperfeições do mercado, a racionalidade limitada e a limitação na capacidade cognitiva dos atores dificultam o ambiente de interação.

Este quadro se fundamenta em cinco preceitos de North (1990): os
problemas por demais complexos são absorvidos em partes; a maximização
é substituída pela satisfação, devido à impossibilidade de se considerar
todas as possíveis alternativas e seus resultados; a busca por alternativas
aos problemas é limitada e estável, as organizações evitam incertezas e
ações estimadas; e são estabelecidos padrões de ações para medir
situações recorrentes. (NORTH, 1990 apud SILVERWOOD, 2005, p.17)

North (1990) aplica seus conceitos, especialmente, ao campo da economia, na intermediação de interações econômicas entre agentes. Neste campo as instituições podem cumprir tanto o papel de melhorar a alocação de recursos, proporcionando a eficiência econômica, o bem-estar social e a distribuição de recursos como, se forem mal formuladas, conduzir à concentração de renda ou à ineficiência na alocação de recursos.

O autor refere-se ainda a um sistema judiciário eficaz, a agências regulatórias firmes e atuantes. Afirma que desta forma, com instituições consolidadas, um país estará apto a mudar de patamar, em termos qualitativos de desenvolvimento. Nesse sentido, é papel do Estado estimular a aprovação de um aparato normativo que dê estabilidade às relações econômicas e sociais e cabe aos atores políticos a negociação e o cumprimento de padrões informais de comportamento que estimulem a cooperação política.

Entende-se, assim, que a regulação e a defesa da concorrência são indispensáveis para a economia de mercado saudável e competitiva, com repercussões em todos os setores da atividade econômica. Matias-Pereira (2009a) explica que o modelo contemporâneo de regulação visa permitir um funcionamento equilibrado e imparcial do mercado concorrencial, com base no pressuposto de que esse mercado, uma vez regulado, é o melhor instrumento para forçar a competição e a melhoria da qualidade na oferta de bens e serviços.

Matias-Pereira (2009a) registra ainda, que a moderna noção de regulação remete à idéia de equilíbrio dentro do sistema regulado, o qual poderá envolver a introdução de interesses externos ao sistema que deverão ser processados pelo regulador de forma que a sua consecução não acarrete a inviabilidade do setor regulado. 
Desde a crise mundial da década de 1930, também decorrente da dinâmica do mercado financeiro, já se sabia da importância da regulação dos mercados e que estes, quando livres e irrestritos, são candidatos freqüentes a crises. Entretanto, conforme destaca Tavares (2009), a junção do capital financeiro globalizado, das políticas tímidas do Banco Central Americano (FED) desde a década de 1990, presidido a época por Alan Greenspan, bem como a permissão da Securities Exchanges Comission (SEC), equivalente à nossa CVM (Comissão de Valores Mobiliários), de normas contábeis limitadas e falhas, proporcionaram à economia americana uma expansão de consumo e investimento calcado num alto grau de endividamento do Estado, das famílias, das empresas e dos bancos, sustentado até o último momento antes do estouro da bolha especulativa. Greenspan foi criticado por fechar os olhos para a desregulamentação bancária, que possibilitou o comportamento altamente especulativo das instituições financeiras e a criação de instrumentos de securitização que permitiam a alavancagem de crédito de maneira descontrolada.

Neste momento, cabe uma breve reflexão sobre 0 porquê da desregulamentação do mercado financeiro norte-americano ter chegado a esta gravidade. Deve-se recordar que a ideologia econômica norte-americana é fortemente fundamentada no pensamento liberalista, concebido por John Locke (1632 - 1704). Nas palavras de Matias-Pereira (2008), Locke acreditava que a existência do Estado resultaria, de certa forma, da necessidade de o ser humano usufruir de liberdade individual, direitos individuais e direito à propriedade. Neste intuito, por meio de um 'contrato social', cada indivíduo concedia ao Estado o poder de aplicar a lei e o direito natural em troca da garantia dos direitos individuais do homem, os quais se tornaram sinônimos de liberdade e propriedade de bens.

Atualmente, o liberalismo se traduz, principalmente, pelo nãointervencionismo estatal nas atividades comerciais e financeiras privadas. É previsível que a falta de regulamentação dos mecanismos financeiros, dentro de mercados naturalmente imperfeitos, acabaria por gerar incongruências. Afinal, conforme Matias-Pereira (2009a), o mercado preocupa-se com os resultados imediatos, de curto prazo, enquanto o Estado tem o papel de orientador da economia, responsável pelo desenvolvimento do país, um compromisso de longo prazo. A falha de equilíbrio entre estes interesses culmina em circunstâncias 
calamitosas como a atualmente vivida, conforme depreende-se do trecho que se segue:

Ela [a crise do subprime] foi apenas o detonador de uma crise financeira mais geral que se vinha gestando lentamente, através de uma excessiva expansão de liquidez, do endividamento e de sucessivas bolhas de preços de ativos, processados pela desregulação e complexidade do novo sistema financeiro privado, montado no governo Clinton e continuado no governo Bush. (TAVARES, 2009, p.3, grifo nosso)

O entendimento da situação exposta reforça os ideais Neoinstitucionalistas abordados anteriormente, onde, no entendimento de North (1990), as instituições são as regras do jogo e os agentes econômicos e as empresas, os jogadores. Por sua vez, o Estado tem a função de fiscalizar a ação dos agentes e certificar, por meio do sistema legal, o respeito às regras do jogo, garantindo, assim, a confiança e estabilidade que o sistema necessita para desenvolver-se de forma sustentável.

Diante dos conceitos expostos, é possível inferir que desvios de conduta das instituições podem ocasionar conseqüências desastrosas para a saúde econômica de um país e que a função reguladora do Estado se faz necessária especialmente para evitar esses desequilíbrios (falhas de mercado intrínsecas ao sistema capitalista). Observa-se, tanto na crise de 1929 como na crise atual, a subutilização dos mecanismos regulares do Estado.

O economista pós-keynesiano, Hyman Minsky, autor do livro Can 'It' Happen Again?, de1982, refere-se à palavra 'It' (Isto) remetendo-se à Grande Depressão da década de 1930. Minsky (1982) formulou sua hipótese de fragilidade financeira, mostrando que economias capitalistas em expansão são naturalmente instáveis e propensas a crises, uma vez que a maioria dos agentes apresenta postura especulativa, resultando em práticas de empréstimos de alto risco.

Neste sentido, o endividamento apresenta um caráter cíclico e instável, dada a estrutura de financiamento que se cria nos períodos de prosperidade. Assim, "é possível constatar que os processos de fragilidade e crises financeiras são gerados endogenamente, e têm seu cerne nas condições de financiamento/ investimento da economia." (MINSKY,1986 apud LACERDA, 2009, p.4)

Conforme observado por Ferrari Filho e Paula (2008), saímos de um "Momento Minsky" - de crescente fragilização financeira gerando uma crise financeira - e passamos para um "Momento Keynes", em que os governos dos 
países afetados pela crise passam a adotar uma política fiscal contra-cíclica, face a crescente deterioração no estado de expectativas dos agentes. Esta deterioração ocasiona uma queda abrupta no valor de ações e de outros ativos financeiros, o que gera progressivos comportamentos coletivos de pânico. Quedas de grande magnitude nos preços podem resultar em um pessimismo generalizado que provoca reduções nos níveis de consumo e de investimentos dos agentes, com impactos macroeconômicos graves que acabam arrastando toda a economia de um país para uma recessão.

Num cenário análogo ao acima desenhado, em 1936, Keynes revolucionou o pensamento macroeconômico com a publicação de sua Teoria geral do emprego, do juro e da moeda, a fim de diagnosticar e superar a recessão decorrente da quebra da bolsa de valores de 1929. O tripé microeconômico dos clássicos - preço, oferta e demanda - no modelo keynesiano se transformou na sustentação macroeconômica: demanda global mais investimento global determinam a renda global, que conjuntamente definem o nível de emprego. O controle dessas variáveis deve se dar por intermédio do Estado. As recessões, segundo Keynes (1982), resultariam da falta de investimentos privados pra absorver as poupanças que seriam geradas a pleno emprego. Ao contrário da prescrição ortodoxa de que o orçamento público deveria obedecer aos princípios de equilíbrio da economia doméstica, o remédio recomendado por Keynes foi o intervencionismo do Estado: aumentar o déficit público em época de recessão e gerar superávits diante de ameaças de inflação. "No varejo, nada funciona melhor do que a 'mão invisível do mercado'. Mas, no atacado, o governo precisa criar condições indispensáveis ao pleno emprego'." (SIMONSEN;CYSNE, 1995, p.204)

\subsection{O Orçamento Público como ferramenta de Planejamento Governamental}

O planejamento se apresenta como instrumento básico para a consecução do bem-estar da coletividade, papel sob responsabilidade do Estado, exposto explicitamente na Constituição Federal de 1988, a qual destitui seu caráter

\footnotetext{
1 "Os economistas têm definido uma situação de pleno emprego como aquela onde todas as pessoas que desejem trabalhar em troca da taxa salarial prevalecente no mercado de trabalho terão condições de obter um trabalho." (MUSGRAVE; MUSGRAVE, 1980, p.448)
} 
unicamente técnico tornando-o um mecanismo jurídico de determinação de execução das atividades governamentais determinantes ao alcance do desenvolvimento econômico e social. Considerando que nem sempre pode-se dispor de bens e serviços no nível ideal para todos, torna-se necessário, neste ambiente de escassez, elaborar e implementar planos, programas, projetos e atividades, com vistas a corrigir desequilíbrios e a promover o ajustamento do desenvolvimento nacional. O plano, programa ou projeto é a expressão física, o documento restante do processo de planejamento, ou seja, o orçamento é entendido como um instrumento do planejamento. De acordo com Matias-Pereira (2009a) planejar é um processo contínuo que fundamenta, antecede e acompanha a elaboração orçamentária.

Na definição de Musgrave e Musgrave (1980), o termo setor público é denominado como aqueles componentes da política econômica governamental que atuam por meio de medidas orçamentárias divididas em três atividades orçamentárias primordiais: o fornecimento de certos bens e serviços, denominados 'bens públicos' (Função Alocativa); ajustes no estado de distribuição de bens e riquezas (Função Distributiva) e; medidas que visem estabilizar o nível de atividade econômica (Função Estabilizadora). Musgrave e Musgrave (1980) explicam ainda que a utilização do orçamento da União para atingir objetivos macroeconômicos é denominado política fiscal ${ }^{2}$ e que esta deve ser formulada no intuito de alavancar ou manter um elevado nível de emprego, uma razoável estabilidade no nível de preços, o equilíbrio na balança de pagamentos e ainda uma taxa aceitável de crescimento econômico. Acontece que os objetivos idealizados não resultam do funcionamento automático do sistema de mercado. Exigem uma orientação por parte da política implementada pelo setor público, a qual é formalizada, também, por intermédio do orçamento.

Os orçamentos documentam a vida financeira de um país em determinado período, normalmente de um ano, contendo o cálculo de despesas e receitas que viabilizam o funcionamento dos serviços públicos ou outros fins projetados pelos

\footnotetext{
2 "O conjunto de medidas financeiras (despesas públicas, impostos, empréstimos, etc) empregadas pelos governos para comando da conjuntura econômica, quer promovendo a volta à prosperidade nas crises de depressão, quer reprimindo um processo inflacionário e também para alterações racionais das estruturas." (BALEEIRO, 1968, p. 42)
} 
governos. A sua importância é imensa e pode ser observada a partir do debate histórico ao seu redor.

A origem do orçamento não se prende a elucubrações de técnicos, nem à preocupação de racionalizar a máquina financeira. Uma penosa e multissecular cadeia de lutas políticas tornou a elaboração orçamentária indispensável ao equilíbrio dos interesses antagônicos em volta do poder. (BALEEIRO, 1968, p.399)

Nesse sentido, o cientista político Aaron Wildavsky (1992) afirma que o processo orçamentário é ainda mais complicado em razão de diferentes desdobramentos políticos que surgem no orçamento.

\begin{abstract}
Tomando como um todo, o orçamento federal é a representação em termos monetários, da atividade governamental. Se a política é considerada em parte, como um conflito entre quais demandas devem prevalecer na determinação da política nacional, então o orçamento registra os resultados desta luta. Se alguém pergunta, "quem recebe o que o governo tem para dar?" encontra as respostas no orçamento. Se a política é considerada um processo no qual o governo mobiliza recursos para resolver problemas prementes, então o orçamento é o centro destes esforços. (WILDAVSKY, 1992, p.8)
\end{abstract}

Ainda conforme entendimento de Wildavsky (1992), o tamanho e forma do orçamento é um problema de sérias disputas políticas. Presidentes, partidos políticos, administradores, parlamentares, grupos de interesses e cidadãos competem entre si em busca de priorizar suas demandas dentro do orçamento. As vitórias e derrotas, os compromissos e as barganhas, os acordos e as esferas de conflitos relacionados ao papel do governo federal na sociedade, tudo aparece no orçamento. "Em seu sentido mais amplo, orçamentar - isto é, a tentativa de alocar recursos financeiros escassos através do processo político com o objetivo de alcançar diferentes visões de bem-estar - encontra-se no centro do processo político" (WILDAVSKY, 1992, p.8).

Neste sentido, pode-se afirmar que o orçamento é um instrumento de planejamento e sua elaboração e mesmo sua execução estão intimamente ligados ao processo político.

O conceito de orçamento público tem sofrido mudanças significativas ao longo do tempo em decorrência da evolução de suas funções. Assim, o entendimento de seu papel atual, como ferramenta de planejamento do governo, produto de um processo político, é facilitado a partir da compreensão histórica do enriquecimento gerado pelos diferentes aspectos aos poucos agregados ao orçamento público. 


\subsubsection{Evolução Conceitual do Orçamento Público}

A história da evolução do orçamento público está intimamente ligada à evolução das instituições democráticas, à ampliação da complexidade da economia e aos avanços dos conhecimentos, especialmente nas áreas de administração e economia. À medida que novos aspectos (econômico, financeiro, administrativo, político, jurídico, contábil, etc) evoluíram e novas funções foram incorporadas ao orçamento, distintas espécies de orçamento foram experimentadas.

$\mathrm{Na}$ abordagem de Giacomoni (2009), o primeiro desenho formalmente acabado de um orçamento público deu-se, em 1822, na Inglaterra, alcunhado posteriormente como orçamento tradicional, que tinha como função principal viabilizar o controle político sobre as finanças públicas, buscando o equilíbrio financeiro e evitando a expansão dos gastos, por meio do confronto entre receitas e despesas, divididas em funções e atividades.

No patamar seguinte, conforme entendimento de Albuquerque, Medeiros e Feijó (2008), o foco deixava de ser simplesmente uma demonstração de gastos e passava a ponderar os benefícios a serem obtidos. Assim, o orçamento de desempenho incorporava a dimensão de programa de trabalho, a fim de medir o desempenho organizacional, por meio de dados quantitativos. Porém, o modelo ainda não se comunicava com um planejamento de políticas públicas.

A partir da década de 1930, com a doutrina keynesiana, o aspecto econômico do orçamento público ganhou importância, passando a ser utilizado como instrumento da política fiscal do governo. Desse modo, plantou-se a semente que deu frutos na década de 60, com o surgimento do PPBS, Planning, Programming and Budgeting System (Sistema de Planejamento, Programação e Orçamento), que implantou a ligação entre o planejamento e o orçamento por meio de programas hierarquizados por prioridades, a partir de objetivos atuais e futuros predefinidos.

Baseada, principalmente, na experiência americana, a Organização das Nações Unidas (ONU) difundiu, por meio de seus manuais, a adoção do orçamento por programas pela América Latina.

No Brasil não foi diferente. A Lei no 4.320 de 1964, que estatui normas gerais de direito financeiro para elaboração e controle dos orçamentos e balanços da União, dos Estados, dos Municípios e do Distrito Federal, contemplou a integração 
entre o planejamento da ação governamental e o orçamento público, através do Orçamento-programa.

Ao final da década de 60, a técnica do Orçamento Base Zero, criada por Peter Phyrr para a empresa Texas Instruments, foi adaptada para a administração pública com intuito de auxiliar na avaliação e na tomada de decisão sobre despesas. A cada período de elaboração do orçamento as despesas são todas reavaliadas sem se basear nos números do exercício anterior, ou seja, a base de comparação é zero. Entretanto, o volume e a complexidade das informações ultrapassavam a capacidade de processamento cognitivo individual e organizacional dificultando as análises técnicas dos tomadores de decisão do Executivo, como informam Albuquerque, Medeiros e Feijó (2008).

Em contraposição ao orçamento base zero, o orçamento incremental é definido por ajustes em relação ao orçamento anterior. A definição do processo incremental está bem apresentada por um de seus maiores formuladores, Aaron Wildavsky (1992), no trecho transcrito a seguir:

\begin{abstract}
Um processo incremental, proveniente de uma base histórica, guiado por noções aceitas de divisões justas, nas quais as decisões são fragmentadas, feitas em seqüência por departamentos especializados e coordenado através de ataques repetidos em problemas e através de múltiplos mecanismos de feedback. O papel dos participantes e suas percepções do poder e interesses de cada um se ajustam para prover uma razoável estabilidade na série de critérios cuja base é calculada. (WILDAVSKY, 1992, p.56)
\end{abstract}

Em 1993, com a aprovação da Lei de Desempenho e Resultados do Governo, o Congresso americano introduziu importantes inovações no planejamento e no orçamento público federal, as quais deram origem ao Novo Orçamento por Desempenho, ou Orçamento por Resultados. De acordo com Matias-Pereira (2009a), reconhece-se que a idéia central do Orçamento por Resultados é que o desempenho é importante, mas deve estar integrado a um sistema de accountability (transparência e mecanismos de prestação de contas) capaz de premiar os bons e punir os maus resultados em termos econômicos e sociais.

Partindo de uma outra realidade, Caiden e Wildavsky (1974), no livro Planning and Budgeting in Poor Countries, onde os autores realizam um diagnóstico dos sistemas orçamentários em países pobres, observa-se que a grande dificuldade de integração entre planejamento e orçamento é causada pela condição de pobreza 
num sentido amplo, que ultrapassa a escassez de dinheiro e se agrava pela insuficiência de capital humano qualificado, pela assimetria de informações e pela deterioração das instituições.

Caiden e Wildavsky (1974) ressaltam ainda que nos países em desenvolvimento o planejamento e a execução financeira das políticas estão descompassadas devido a descontinuidade dentro do processo de planejamento, autorização do gasto e liquidação da despesa. Está situação é agravada pela instabilidade econômica e social (crises, dependência de capital estrangeiro, inflação) e pelo cálculo irreal gerado pela superestimativa de despesas e subestimativa de receitas.

Neste contexto, a análise do processo orçamentário brasileiro não se distancia desta perspectiva pautada nas variáveis de incerteza e pobreza. A seção seguinte, passa a abordar o orçamento público brasileiro mais detalhadamente.

\subsubsection{Orçamento Público Federal Brasileiro}

A importância do sistema e do processo orçamentário brasileiro pode ser dimensionada pelo tratamento que o assunto recebe na Constituição Federal, a qual determina um encadeamento lógico e sistêmico ao planejamento da ação governamental.

Conforme retrata Giacomoni (2009) é na Constituição Imperial de 1824 que surgem as primeiras exigências no sentido de elaborar orçamentos formais por parte das instituições imperiais. Desde então, o orçamento foi submetido a diversas mudanças refletindo as transformações políticas e administrativas do país, culminando na atual Constituição Federal de 1988, onde o orçamento público ganhou atenção especial com uma seção integralmente dedicada a estabelecer as linhas gerais de atuação no processo orçamentário, como pode ser observado no trecho seguinte:

Art. 165. Leis de iniciativa do Poder Executivo estabelecerão:

I - o plano plurianual;

II - as diretrizes orçamentárias;

III - os orçamentos anuais. 
$\S 1^{\circ}$ - A lei que instituir o plano plurianual estabelecerá, de forma regionalizada, as diretrizes, objetivos e metas da administração pública federal para as despesas de capital e outras delas decorrentes e para as relativas aos programas de duração continuada.

$\S 2^{0}$ - A lei de diretrizes orçamentárias compreenderá as metas e prioridades da administração pública federal, incluindo as despesas de capital para o exercício financeiro subseqüente, orientará a elaboração da lei orçamentária anual, disporá sobre as alterações na legislação tributária e estabelecerá a política de aplicação das agências financeiras oficiais de fomento.

[...] $\S 4^{\circ}$ - Os planos e programas nacionais, regionais e setoriais previstos nesta Constituição serão elaborados em consonância com o plano plurianual e apreciados pelo Congresso Nacional.

$\S 5^{\circ}$ - A lei orçamentária anual compreenderá:

I - o orçamento fiscal referente aos Poderes da União, seus fundos, órgãos e entidades da administração direta e indireta, inclusive fundações instituídas e mantidas pelo Poder Público;

II - o orçamento de investimento das empresas em que a União, direta ou indiretamente, detenha a maioria do capital social com direito a voto;

III - o orçamento da seguridade social, abrangendo todas as entidades e órgãos a ela vinculados, da administração direta ou indireta, bem como os fundos e fundações instituídos e mantidos pelo Poder Público. (BRASIL, 1988, Capítulo II Seção II Artigo 165, grifo nosso )

No entendimento de Giacomoni (2009), a Carta Magna de 1988 ampliou o poder do Congresso de interferir no processo orçamentário, apesar dos curtos prazos que prejudicam um exame mais consistente e profundo da matéria. A Constituição contemporânea reforçou a concepção que associa planejamento e orçamento como elos de um mesmo sistema, ao tornar obrigatória a elaboração de planos plurianuais (substituindo os orçamentos plurianuais de investimentos) abrangendo as despesas de capitais e demais programas de duração continuada.

Contudo, a principal inovação relacionada a Planejamento e Orçamento trazida pela Constituição de 1988 foi o estabelecimento de três peças, todas elaboradas pelo Executivo, submetidas à apreciação e votação do Legislativo e, por fim, sancionadas e executadas pelo poder Executivo: o plano plurianual (PPA), a lei de diretrizes orçamentárias (LDO) e a lei orçamentária anual (LOA), que passarão a ser analisados na seqüência. Essas leis se organizam numa seqüência lógica: primeiro o PPA é sancionado (contemplando um período de 4 anos), e depois, anualmente a LDO e a LOA. Assim, o ciclo orçamentário, disposto no art. 166 da Constituição Federal, se desdobra nas fases indicadas na llustração 3 , a seguir: 


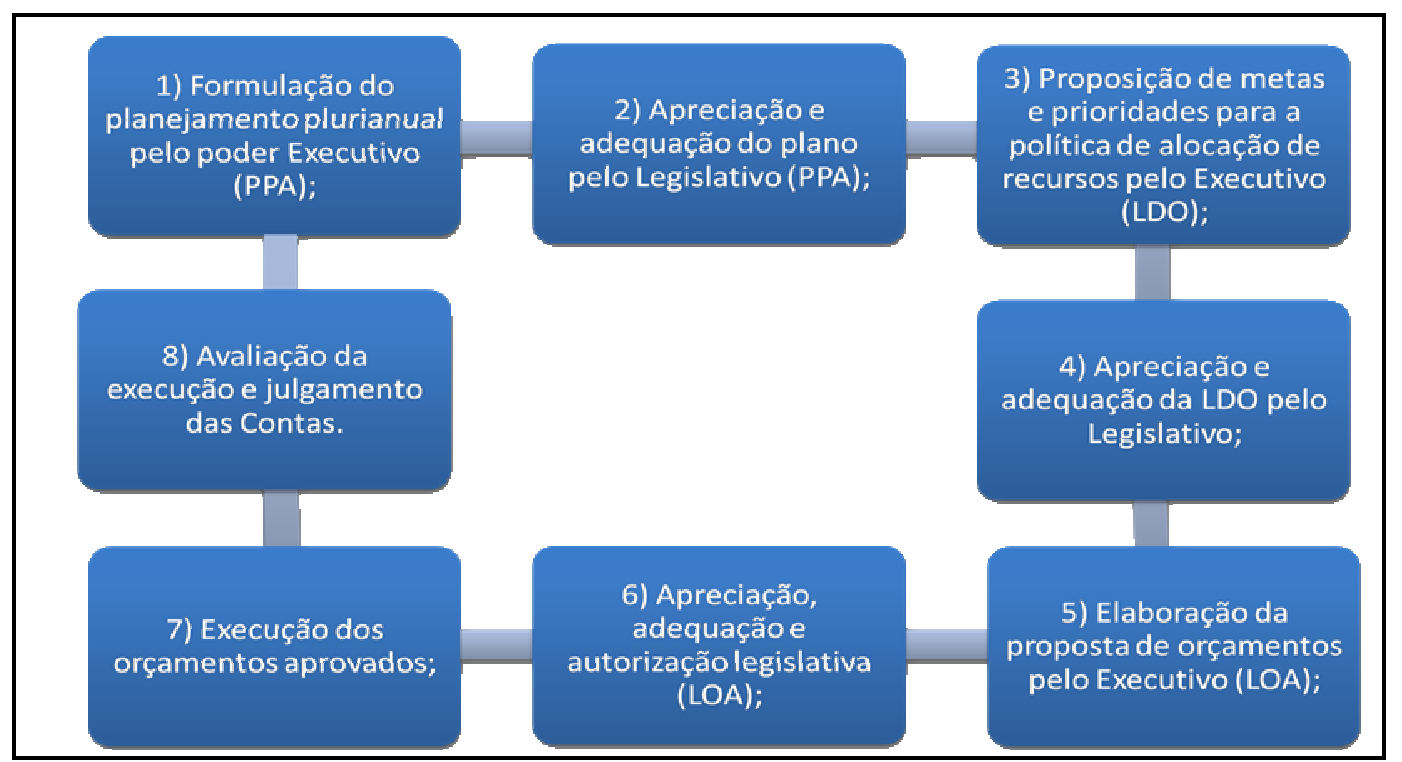

Ilustração 3: Ciclo Orçamentário Simplificado

Fonte: SANCHES (1993, p. 4)

O PPA é o instrumento que expressa o modo como o governo enxerga e procura construir o desenvolvimento do Estado, com ênfase no planejamento de médio prazo. Os ideais básicos que norteiam o PPA, de acordo com o Manual Técnico de Orçamento de 2009 (MTO) da Secretaria de Orçamento Federal (SOF), são: a identificação clara dos objetivos e das prioridades do governo; a integração do planejamento e do orçamento; a promoção da gestão empreendedora; a garantia da transparência; o estímulo às parcerias; a gestão orientada para resultados e a organização das ações de Governo em programas.

Em seguida, passa-se à elaboração da LDO que é a articulação entre o PPA e a LOA. Albuquerque, Medeiros e Feijó (2008) esclarecem que a LDO age como uma balança entre a estratégia traçada no início de um governo e as reais possibilidades que vão se apresentado no decorrer da implementação do plano plurianual. Neste sentido, segundo o MTO (2009), a LDO estabelece prioridades e metas da Administração Pública, estrutura e organização dos orçamentos, dívida pública federal, metas e riscos fiscais, fixação de critérios para limitação de empenho e movimentação financeira, entre outros também elencados na Lei de Responsabilidade Fiscal - LRF.

Por fim, aborda-se a lei que disciplina todas as ações que impliquem em despesas do governo federal, a Lei Orçamentária Anual (LOA). Conforme exposto anteriormente, a LOA é subdividida em Orçamento Fiscal, Orçamento da Seguridade Social e Orçamento de Investimento. 
Para nortear o desenvolvimento do seu processo de trabalho, a Secretaria de Orçamento e Finanças (SOF) toma como base um conjunto de premissas que norteiam a elaboração do PLOA (Projeto de Lei Orçamentária Anual):

- O orçamento visto como instrumento de viabilização do planejamento governamental;

- Destaque da finalidade do gasto, transformando o orçamento em instrumento efetivo de programação, possibilitando a implantação da avaliação dos programas e ações;

- Aprimoramento das metodologias de cálculo das despesas obrigatórias;

- Cronograma gerencial e operacional com etapas claramente especificadas, produtos definidos e configurados, participação organizada e responsável dos agentes envolvidos e divulgação de informações, garantindo confiança e credibilidade à Administração;

- Ciclo orçamentário desenvolvido como processo contínuo de análise e decisão ao longo de todo o exercício;

- Incorporação das repercussões de decisões geradas em uma das instâncias, que afetam o desenvolvimento da outra;

- Criação de instrumentos de atualização das projeções do orçamento para subsidiar a tomada de decisão no âmbito das metas fiscais a serem atingidas; $\mathrm{e}$

- Elaboração do projeto, aprovação e execução da lei orçamentária realizadas de modo a evidenciar a transparência da gestão fiscal.

Compreendidos estes conceitos, pode-se prosseguir à análise da interação entre 0 orçamento e a conjuntura. 


\subsection{O Orçamento Público e a Conjuntura}

Baleeiro (1968) explica que nos países em progresso, admitido como estável o poder aquisitivo da moeda, as arrecadações tendem a crescer a cada ano, graças ao aumento da população, incremento físico ou tecnológico da produção, entre outras causas. Essa observação encorajava o otimismo dos elaboradores de orçamento que ao prever as receitas para o próximo exercício, baseavam-se na média de crescimento do triênio anterior (orçamento incremental). Contudo, as flutuações econômicas, a expansão das intervenções estatais e a célere desvalorização da moeda agravaram-se com 0 advento da globalização, principalmente após a Primeira Guerra Mundial. O Estado cada vez mais necessita de maiores recursos, além dos que costumava exigir.

As crises assumem aspectos muito mais intensos do que no passado. Por outro lado, aperfeiçoaram-se as estatísticas possibilitando cálculos mais seguros e estruturados em dados mais realísticos, inclusive em estudos de sensibilidade dos impostos à conjuntura. Esta preocupação reside na existência de uma implicação fiscal em relação à receita, na qual o total do gasto, o déficit ou superávit nas contas governamentais, estimula ou restringe a economia.

Nesse sentido, Baleeiro (1968) argumenta que o orçamento, por seu aspecto econômico, é estabilizador e amortecedor dos choques da conjuntura e pode concorrer com medidas para a modificação da estrutura do país, inclusive no sentido de seu desenvolvimento.

Ademais, baseado na leitura de Matias-Pereira (2009a), o orçamento público, em sua concepção moderna, é um instrumento indispensável à viabilização e à implementação da política governamental, de forma a auxiliar o Executivo nas várias etapas do processo administrativo de programação, execução e controle.

Os autores aqui citados constituem as principais referências dentro desta pesquisa para a fundamentação conceitual da dinâmica econômica e de suas inconsistências. Ademais, a presente pesquisa colheu informações, por meio de estatísticas, estudos e relatórios, junto a instituições nacionais e internacionais, reconhecidamente competentes acerca da temática: Instituto Brasileiro de Geografia e Estatística (IBGE), Instituto de Pesquisa Avançada (IPEA), Banco Central do Brasil (BCB), Câmara dos Deputados, Senado Federal, Ministério da Fazenda (MF), 
Ministério do Planejamento, Orçamento e Gestão (MPOG), Organização para a Cooperação e Desenvolvimento Econômico (OCDE), Fundo Monetário Internacional (FMI), Banco Mundial, entre outros.

Desta forma, entende-se que a análise do orçamento público permite a compreensão dos efeitos e das perspectivas de transformações advindas da crise e de quais medidas serão adotadas pelos governantes para combater seus possíveis efeitos no Brasil. Parte-se, então, à seção seguinte que apresentará os métodos e técnicas utilizados na consecução desta pesquisa. 


\section{MÉTODOS E TÉCNICAS DE PESQUISA}

Este capítulo visa apresentar os aspectos metodológicos da pesquisa, considerando que "Pesquisar é o esforço desenvolvido pelo investigador para coletar informações e dados essenciais a fim de responder a uma pergunta motivadora, e dessa forma alcançar os objetivos da pesquisa" (MATIAS-PEREIRA, 2007, p.44).

\subsection{Delineamento da Pesquisa}

À luz do tema apresentado e dos objetivos propostos, a presente pesquisa pode ser classificada, quanto à sua finalidade, como exploratória. "Estas pesquisas têm como objetivo proporcionar maior familiaridade com o problema, com vistas a torná-lo mais explícito" (GIL, 2007, p. 41) e são realizadas em áreas com escassez de conhecimento acumulado e sistematizado.

Tendo em vista que o estudo proposto apresenta peculiaridades quanto à contemporaneidade, complexidade e amplitude do tema, as técnicas de pesquisa adotadas serão a pesquisa bibliográfica, a pesquisa documental e a entrevista.

De acordo com Lakatos e Marconi (2007), a pesquisa documental tem como fonte de coleta de dados documentos escritos ou não, constituindo o que se denomina de fontes primárias. As fontes de documentos que este trabalho explorou foram:

Arquivos Públicos: documentos oficiais (leis), publicações parlamentares (documentos, projetos de lei, relatórios, notas técnicas).

Arquivos Particulares: documentos de instituições de ordem privada e pública.

Fontes Estatísticas: fatores econômicos, oriundos principalmente do Instituto Brasileiro de Geografia e Estatística (IBGE).

Já a pesquisa bibliográfica (ou de fontes secundárias) abrange toda a bibliografia já tornada pública em relação ao tema de estudo, a fim de colocar o pesquisador em contato direto com tudo o que foi escrito, dito ou filmado sobre determinado assunto. Neste intento, os tipos e fontes bibliográficas a serem empregadas neste trabalho são: 
Imprensa Escrita: revistas e jornais (material e virtual) reconhecidos e independentes.

Publicações: livros e pesquisas.

Considerando ainda a classificação de Lakatos e Marconi (2007), a entrevista caracteriza-se pelo encontro de duas pessoas com a finalidade de obtenção de informações a respeito de determinado assunto por meio de conversação de natureza profissional. "É um procedimento utilizado na investigação social, para a coleta de dados ou para ajudar no diagnóstico ou no tratamento de um problema social" (LAKATOS; MARCONI, 2007, p.197). Há diferentes tipos de entrevista que variam de acordo com o propósito do entrevistador. Na presente pesquisa, o tipo adotado foi a Entrevista Estruturada (também denominada padronizada ou fechada) que segue um roteiro previamente estabelecido em um formulário. Os detalhamentos de métodos e técnicas aplicados à entrevista serão apresentados nas próximas subseções.

Este estudo é dividido em três etapas explicitadas a seguir, em ordem cronológica, integrando o tema e a técnica utilizada:

- 1a etapa: Consistiu em pesquisa bibliográfica baseada prioritariamente em obras literárias a fim de proporcionar um entendimento teórico sobre Teoria Econômica Neoinstitucionalista, Finanças Públicas, evolução conceitual do orçamento público e suas funções e, por fim, as raízes da atual crise financeiro-econômica.

- 2a etapa: Investigou as atualidades por meio de publicações da imprensa escrita e de arquivos particulares sobre aspectos da crise no mundo e no Brasil, inclusive as medidas adotadas pelos governantes a esse respeito.

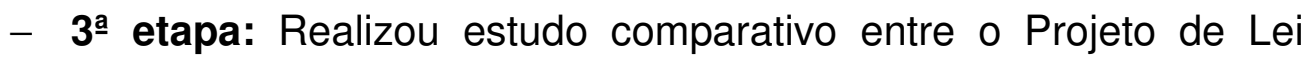
Orçamentária Anual (PLOA) de 2009, a própria Lei Orçamentária Anual (LOA) de 2009, modificações posteriores e resultados consolidados. A presente etapa fundamentou-se em pesquisa documental de publicações parlamentares e documentos de 
instituições oficiais, além de citações de trechos das entrevistas realizadas a fim de esclarecer e ilustrar o tema.

Enfim, o delineamento da pesquisa refere-se ao planejamento da pesquisa em sua dimensão mais ampla, como sugere as etapas definidas acima. Entre outros aspectos além das fontes em que são coletadas as informações, o delineamento considera as relações entre as variáveis envolvidas.

\subsection{Variáveis da Pesquisa}

De acordo com Lakatos e Marconi (2007), as variáveis que serão confrontadas neste estudo são classificadas como:

Variável Independente ou Antecedente (X): aquela que influencia, determina ou afeta outra variável. É o fator determinante, condição ou causa para determinado resultado/efeito.

No âmbito desta pesquisa, a variável independente caracteriza-se como a crise financeira e econômica mundial.

Variável Dependente ou Critério (Y): consiste naqueles valores (fenômenos, fatores) a serem explicados ou descobertos, em virtude de serem influenciados, determinados ou afetados pela variável independente.

Neste enquadramento situam-se o orçamento público da União e os indicadores macroeconômicos brasileiros.

Variável Interveniente (W): é aquela que se coloca entre a variável independente $(X)$ e a dependente $(Y)$, tendo como função ampliar, reduzir ou anular a influência de $X$ sobre $Y$. Sendo que para se considerar uma variável como interveniente, é preciso reconhecer, primeiramente, a relação original entre $\mathrm{X}$ e $\mathrm{Y}$; posteriormente, a relação entre $\mathrm{X}$ e $\mathrm{W}$; e por fim, a relação entre $\mathrm{Y}$ e $\mathrm{W}$.

A variável interveniente é considerada, neste contexto, como a intervenção estatal no intuito de amortecer os impactos da crise e evitar seqüelas graves.

É valido enfatizar que a presente pesquisa tem natureza qualitativa e que o estudo das variáveis citadas ocorrerá de maneira distinta à pesquisa experimental, onde o pesquisador manipula e controla a variável independente. As variáveis deste estudo são complexas e incontroláveis por parte do pesquisador, ao qual cabe 
apenas o papel de investigador de suas interações naturais. Esta característica é um fator determinante para a definição das técnicas de pesquisa que serão detalhadas a seguir.

\subsection{População e amostra}

A adoção da técnica de entrevista neste trabalho ocorreu com o intuito de dar um tratamento mais analítico os dados apresentados, ou seja, dar vida aos números. Para atender a esta necessidade qualitativa, e não quantitativa, foram realizadas quatro entrevistas com especialistas reconhecidos na área concernente ao presente estudo:

1) Cristiano Ordones Portugal - Assessor Econômico do Ministério do Orçamento, Planejamento e Gestão.

2) Maria Liz de Medeiros Roarelli - Consultora Legislativa do Senado Federal - Área de Orçamento.

3) Paulo Henrique Feijó - Coordenador Geral de Contabilidade da Secretaria do Tesouro Nacional.

4) Milko Matijascic - Chefe da Assessoria Técnica da Presidência do Instituto de Pesquisa Econômica Aplicada (IPEA) e Economista-Chefe do grupo de estudos da crise do IPEA.

A divulgação dos nomes, cargos e instituições dos entrevistados, bem como o conteúdo de suas entrevistas foi devidamente autorizada por meio do TERMO DE CONSENTIMENTO LIVRE E ESCLARECIDO (apêndice B), assinado por todos.

Os entrevistados foram recomendados pelos orientadores desta monografia em decorrência de seus notórios conhecimentos e por possuírem experiência em instituições de grande relevância no contexto desta pesquisa, dando credibilidade às suas opiniões e justificando a preferência pela divulgação de suas identidades. 


\subsection{Procedimentos e instrumentos utilizados na coleta e análise do conteúdo}

Conforme já comentado, o tipo de entrevista adotado foi o estruturado. Realizado a partir de um formulário de questões pré-estabelecido, que não sofreu interferência do entrevistador no decorrer das respostas. Lakatos e Marconi (2007) destacam que a vantagem deste procedimento de padronização das perguntas é a possibilidade de comparação entre as respostas. "O formulário é um dos instrumentos essenciais para a investigação social, cujo sistema de coleta de dados consiste em obter informações diretamente do entrevistado" (LAKATOS; MARCONI, 2007, p. 214) O formulário utilizado nas entrevistas (Apêndice A) é composto por três perguntas abertas, elaboradas com base nos objetivos geral e específicos deste estudo e validado pelos professores orientadores desta monografia.

A primeira questão fez referência à pergunta de trabalho, proposta na introdução, e buscou proporcionar liberdade e abrangência na resposta do entrevistado.

A segunda questão busca informações focadas na atuação proativa do Governo Federal frente à crise, envolvendo o orçamento público da União.

Já a terceira pergunta pede uma reflexão sobre a eficácia das medidas governamentais e, se for o caso, o que poderia ser acrescentado.

Estas questões foram postas nos dias 15 e 18 de junho de 2009, pessoalmente, e tiveram duração média de 16 minutos cada, devidamente registradas por um aparelho gravador. A gravação tem a vantagem de registrar todas as expressões orais, deixando o entrevistador livre para prestar toda a sua atenção ao entrevistado.

Posteriormente, as entrevistas foram transcritas e corrigidas quanto aos vícios da expressão oral, sem comprometimento do conteúdo, disponível nos apêndices de C a F. 


\subsection{Período de realização da pesquisa}

As pesquisas relacionadas ao trabalho como um todo vêm sendo realizadas desde o mês de outubro de 2008 e perdurou até a véspera da finalização em meados de junho de 2009.

As entrevistas foram consumadas nos dias 15 de junho com Cristiano Ordones Portugal e Maria Liz de Medeiros Roarelli; e 18 de junho com Paulo Henrique Feijó e Milko Matijascic. 


\section{ANÁLISE DA INTERAÇÃO CRISE - ORÇAMENTO}

\subsection{O Contexto de Crise: Aspectos Estruturais}

A presente crise originou-se, principalmente ${ }^{3}$, com a política monetária expansionista dos Estados Unidos da América (EUA) valendo-se de sucessivos cortes na taxa de juros que, de acordo com Marques (2009), era de 16\% em 1981, passando para taxas entre $2,5 \%$ e $4 \%$ no período compreendido de 1992 a 2001, reduzidas a menos de $1 \%$ em 2003, gerando a concessão indiscriminada de créditos, principalmente para a aquisição de imóveis. Para conter a febre especulativa, as taxas de juros foram elevadas em até $3 \%$ no ano de 2007, momento em que a inadimplência tornou-se insustentável, chegando a $15,5 \%$, segundo dados do IPEA (2008), arrastando o sistema financeiro norte-americano, complexamente interligado, para uma crise de liquidez, que se tornou uma crise financeira e posteriormente, econômica.

O boom de inadimplência causada, em parte, pela alta nas taxas de juros pode ser compreendida a partir de uma análise simplificada da natureza dos financiamentos imobiliários nos EUA. O segmento denominado subprime, ou seja, mutuários sem comprovação de renda ou com histórico de crédito duvidoso (até mesmo imigrantes) passaram a ter ampla participação no recebimento de financiamentos. Na seqüência, a llustração 4 demonstra o crescimento do financiamento subprime no mercado dos EUA, e a llustração 5 evidencia a diferença de funcionamento do crédito subprime em relação ao produto tradicional.

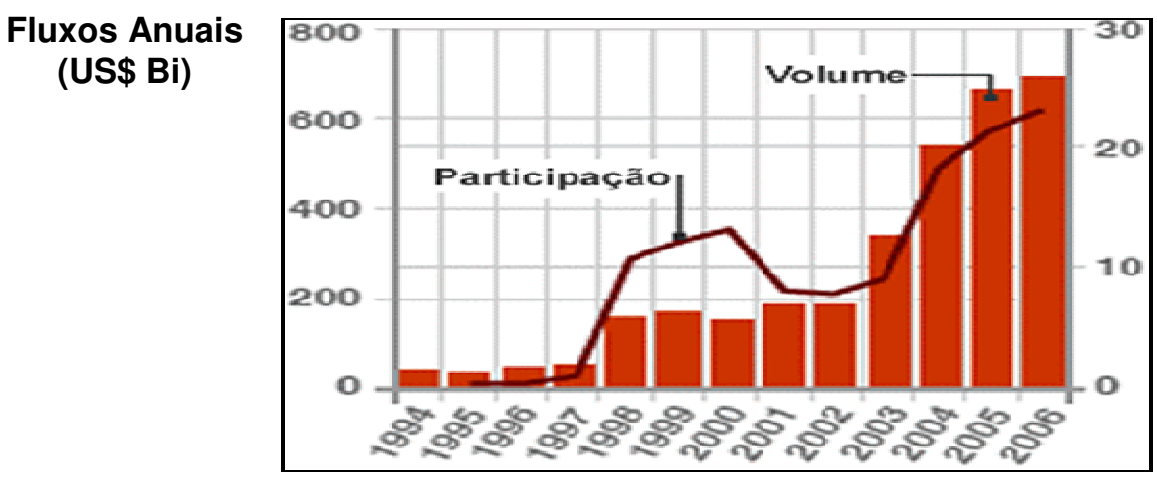

Ilustração 4: Evolução dos Financiamentos Subprime. Fonte: Carta IEDI n. 300.

\section{Participação no mercado (\%)}

\footnotetext{
${ }^{3}$ É valido ressaltar que não se pode apontar um fator isolado como causa da crise, mas um conjunto de causas que se encadearam ao longo do tempo. Este trabalho não se propõe a discutir todas, e sim as principais.
} 


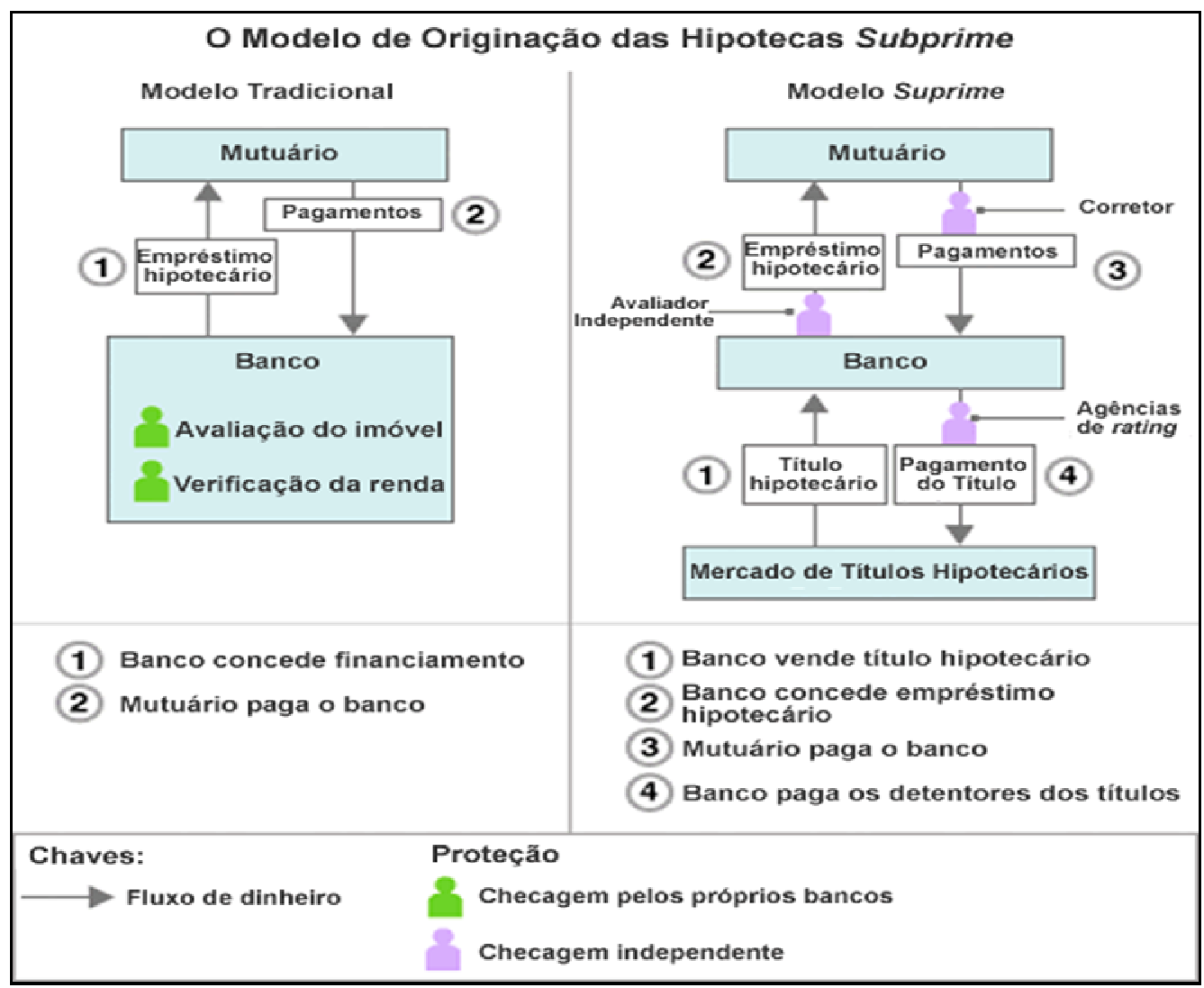

Ilustração 5: O modelo de Originação das Hipotecas Subprime.

Fonte: Carta IEDI n. 300

O volume contratado no mercado internacional de subprime era de US $\$ 65$ bilhões em 1995, crescendo vertiginosamente no decorrer dos anos, chegando a mais de US\$ 1 trilhão em 2007. Marques (2009) confirma que a inadimplência atingiu 5 milhões de moradias.

A gravidade da conjuntura financeira nos Estados Unidos ficou estampada depois de setembro de 2008 com a quebra do Lehman Brothers, o 4ํㅡㄹ maior banco de investimentos dos EUA, após um prejuízo de US\$ 3,9 bilhões no $2^{\circ}$ trimestre de 2008 e desvalorização de $95 \%$ no valor de suas ações em 19 meses. A decisão do FED de deixar o Lehman Brothers à própria sorte foi muito questionada, pois, este fato desencadeou um "efeito dominó" nos sistemas financeiros, como explica a Carta de Conjuntura 2008 do IPEA:

Em seguida ao pedido de falência do Lehman, diversos outros grandes bancos nos Estados Unidos e Europa quebraram ou foram adquiridos por concorrentes, em todos os casos apresentando grandes perdas financeiras. O AIG [American Internarional Group, Inc - maior empresa de seguros dos EUA] recebeu um empréstimo de US\$ 85 bilhões do FED. Levantamento realizado pelo Financial Times indica que, considerando apenas as maiores instituições financeiras norte-americanas, européias e japonesas, as perdas atingiram US\$ 586 bilhões. (IPEA, 2008, p.5) 
Entretanto, segundo Marques (2009), o sinal amarelo vinha desde 2007 com o congelamento de 2 bilhões de euros dos fundos Parvest Dynamic ABS, BNP Paribas ABS Euribor e BNP Paribas ABS Eonia, pelo BNP Paribas Investment Partners em decorrência da inadimplência de pagamentos do crédito subprime nos EUA. A American Home Mortage, uma das maiores empresas de crédito hipotecário nos EUA, pediu concordata. O Bank of America comprou a Countrywide Financial e o Merril Lynch, outra gigante do setor (por um terço do valor de mercado); assim como o JP Morgan comprou o Bear Stearns (O JP Morgan desembolsou US\$ 1 bilhão enquanto o FED assumiu US\$29 bilhões em ativos "tóxicos").

Os dois maiores bancos de investimento dos EUA, Goldman Sachs e Morgan Stanley optaram por diminuir seus riscos transformando-se em holding. Uma das maiores instituições do ramo de empréstimo em poupança dos EUA, o Washington Mutual, faliu. A Freddie Mac e a Fannie Mae, detentoras de aproximadamente 75\% das hipotecas nos EUA e com passivos em torno de US\$ 5,4 trilhões, foram oficialmente estatizadas, números do IPEA (2008). A Ilustração 6 demonstra a gigantesca desvalorização dos ativos de importantes instituições financeiras em menos de 2 anos:

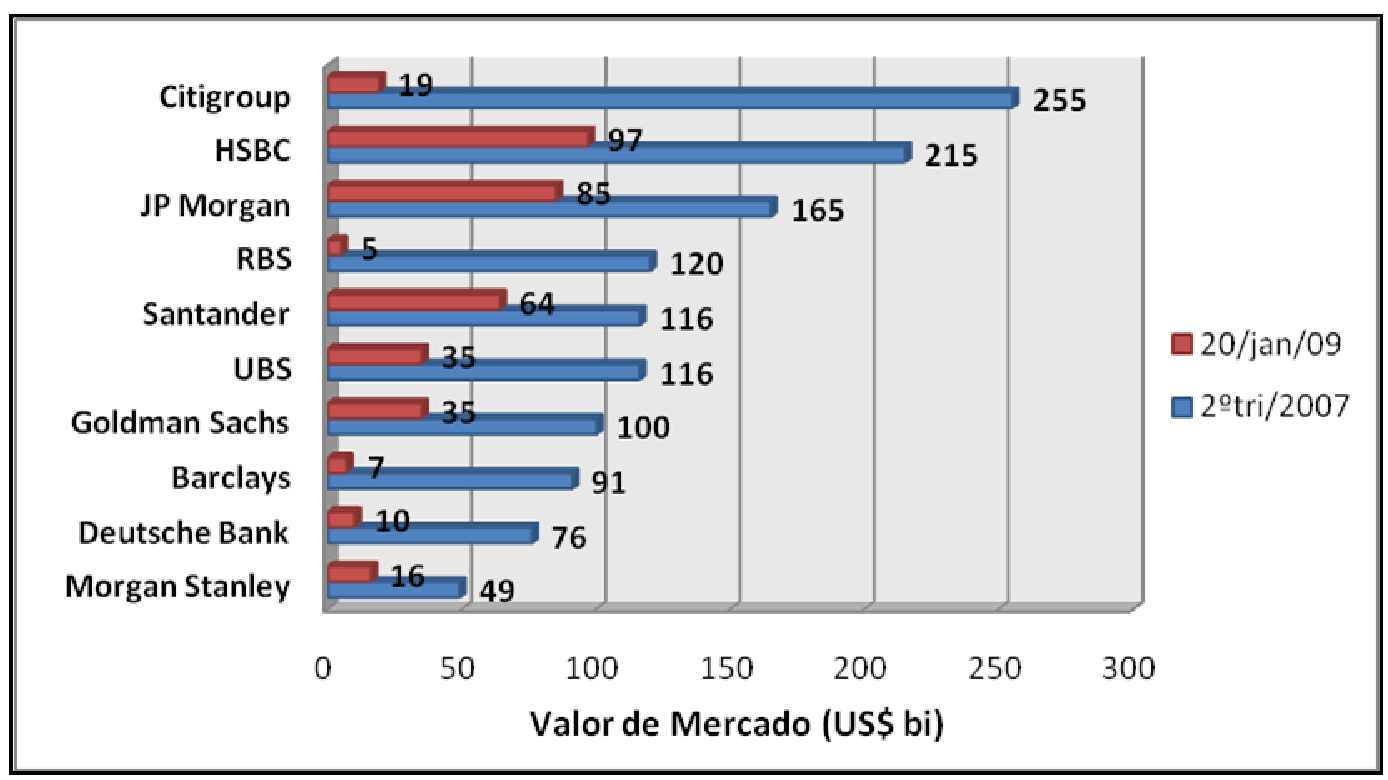

Ilustração 6: Desvalorização de Ativos Bancários Fonte: Ministério da Fazenda, 2008.

Diante do desmoronamento do sistema financeiro, os governos optaram por adotar, a princípio, esforços mais vigorosos no âmbito fiscal e creditício, buscando 
atenuar as perdas envolvendo operações subprime, para, posteriormente, restabelecer a confiança no sistema financeiro.

Estes esforços podem ser observados por meio dos recursos injetados no mercado monetário pelos bancos centrais dos EUA (FED), da área do Euro (BCE), do Japão (BoJ), da Austrália (RBA), Inglaterra (BoE), Canadá (BNS), Suécia (SRB), Nova Zelândia (RBNZ), México (Banxico) e Coréia (BoK), e por meio das políticas de incentivo adotadas, conforme resume cronologicamente a Tabela 1 a seguir:

Tabela 1: Principais medidas adotadas por Bancos Centrais selecionados

\begin{tabular}{|c|c|c|}
\hline Data & Instituição & Evento \\
\hline $10 / 08 / 2007$ & $\begin{array}{l}\text { FED, BCE, BoJ e } \\
\text { RBA }\end{array}$ & Injetaram US\$ 300 bilhões para garantir liquidez ao sistema \\
\hline $18 / 09 / 2007$ & FED & $\begin{array}{l}\text { Iniciou ciclo de redução da taxa básica de juros que passou de } \\
5,25 \% \text { para } 4,75 \%\end{array}$ \\
\hline $12 / 12 / 2007$ & $\begin{array}{l}\text { FED, BCE, BoE e } \\
\text { BoC }\end{array}$ & $\begin{array}{l}\text { Anunciaram operação coordenada para garantir a liquidez dos } \\
\text { mercados financeiros }\end{array}$ \\
\hline $12 / 12 / 2007$ & FED, BCE e BNS & Anunciam criação de linha de swap de moedas \\
\hline $11 / 03 / 2008$ & FED & $\begin{array}{l}\text { Introduziu uma nova linha de empréstimos - Term Securities } \\
\text { Lending Facility (TSLF) }\end{array}$ \\
\hline $16 / 03 / 2008$ & FED & $\begin{array}{l}\text { Anunciou nova linha de empréstimos de curto prazo para os } \\
\text { bancos elegíveis a realizar operações com o FED - Primary } \\
\text { Dealer Credit Facility (PDCF) }\end{array}$ \\
\hline $21 / 04 / 2008$ & BoE & Anunciou medidas para prover liquidez ao sistema \\
\hline $14 / 09 / 2008$ & FED & Ampliação no rol de colaterais aceitos no âmbito do PDCF \\
\hline $14 / 09 / 2008$ & FED & $\begin{array}{l}\text { Incremento de US\$ } 25 \text { bilhões no total de recursos disponíveis no } \\
\text { âmbito do TSLF e aumento da freqüência dos leilões que } \\
\text { passaram a ser semanais. }\end{array}$ \\
\hline $15 / 09 / 2008$ & FED & Injetou US\$ 50 bilhões no mercado monetário \\
\hline $15 / 09 / 2008$ & $\begin{array}{l}\text { BCE, BoE, BNS e } \\
\text { RBA }\end{array}$ & $\begin{array}{l}\text { Operação conjunta de injeção de recursos nos mercados } \\
\text { financeiros }\end{array}$ \\
\hline $16 / 09 / 2008$ & $\begin{array}{l}\text { FED, BCE, BoE, } \\
\text { BNS, BoJ e RBA }\end{array}$ & $\begin{array}{l}\text { Nova injeção de recursos nos mercados de curto prazo, somando } \\
\text { US } \$ 209 \text { bilhões }\end{array}$ \\
\hline $18 / 09 / 2008$ & $\begin{array}{l}\text { FED, BCE, BoE, } \\
\text { BNS, BoJ e BoC }\end{array}$ & $\begin{array}{l}\text { Ação coordenada de injeção de liquidez nos mercados } \\
\text { monetários }\end{array}$ \\
\hline
\end{tabular}




\begin{tabular}{|c|c|c|}
\hline $19 / 09 / 2008$ & FED & $\begin{array}{l}\text { Extensão dos non-recourse loans (empréstimos que são pagos } \\
\text { com o lucro das aplicações) para instituições depositantes e } \\
\text { holdings de bancos }\end{array}$ \\
\hline $24 / 09 / 2008$ & $\begin{array}{l}\text { FED, SRB, RBA e } \\
\text { bancos centrais de } \\
\text { Noruega e } \\
\text { Dinamarca }\end{array}$ & $\begin{array}{l}\text { Criação de novas linhas de swap de moeda com os bancos } \\
\text { centrais da Suécia (SRB), Austrália (RBA) e bancos centrais de } \\
\text { Noruega e Dinamarca }\end{array}$ \\
\hline 07/10/2008 & FED & $\begin{array}{l}\text { Anunciou criação de linha de crédito para aquisição de } \\
\text { commercial papers (Commercial Paper Funding Facility) }\end{array}$ \\
\hline 08/10/2008 & BoE & $\begin{array}{l}\text { Anunciou pacote para recapitalizar o sistema bancário, no valor } \\
\text { total de } £ 500 \text { bilhões. }\end{array}$ \\
\hline 08/10/2008 & $\begin{array}{l}\text { FED, BCE, BoE, } \\
\text { BNS, BoC e SRB }\end{array}$ & $\begin{array}{l}\text { Ação coordenada de redução das respectivas taxas básicas de } \\
\text { juros. FED cortou a taxa de } 2 \% \text { para } 1,5 \% \text {. O BCE reduziu a taxa } \\
\text { de } 4,25 \% \text { para } 3,75 \% \text {. O BoE diminuiu a taxa de } 5 \% \text { para } 4,5 \% \text {. } \\
\text { O BoC reduziu a taxa básica de } 3,0 \% \text { para } 2,5 \% \text {. O SRB reduz } \\
\text { taxa básica de } 4,75 \% \text { para } 4,25 \% \text {. O BNS diminui a faixa de } \\
\text { variação para a taxa indicativa que antes era entre } 2,25 \% \text { e } \\
3,25 \% \text { para } 2 \% \text { e } 3 \%\end{array}$ \\
\hline $13 / 10 / 2008$ & $\begin{array}{l}\text { FED, BCE, BoE e } \\
\text { BNS }\end{array}$ & $\begin{array}{l}\text { Financiamento ilimitado em dólar aos bancos europeus pelos } \\
\text { prazos de } 7,28 \text { e } 84 \text { dias }\end{array}$ \\
\hline $14 / 10 / 2008$ & FED e BoJ & Expansão da linha de swap de moeda (ilimitado) \\
\hline $21 / 10 / 2008$ & FED & $\begin{array}{l}\text { Criação do Programa de Financiamento para Investidor do } \\
\text { Mercado Monetário (Money Market Investor Funding Facility - } \\
\text { MMIFF) }\end{array}$ \\
\hline $28 / 10 / 2008$ & FED e RBNZ & $\begin{array}{l}\text { Criação de linha de swap de moeda com o banco central da Nova } \\
\text { Zelândia }\end{array}$ \\
\hline $29 / 10 / 2008$ & $\begin{array}{l}\text { FED, BACEN, } \\
\text { Banxico, BoK e } \\
\text { autoridade } \\
\text { monetária de } \\
\text { Cingapura }\end{array}$ & $\begin{array}{l}\text { Anúncio da criação de linhas de swap de moedas com os bancos } \\
\text { centrais do Brasil (BACEN), México (Banxico), Coréia (BoK) e } \\
\text { autoridade monetária de Cingapura. }\end{array}$ \\
\hline $25 / 11 / 2008$ & FED & $\begin{array}{l}\text { Anúncio da criação de um programa para estimular o crédito ao } \\
\text { consumidor e a atividade econômica (Term Asset-Backed } \\
\text { Securities Loan Facility - TALF) }\end{array}$ \\
\hline $16 / 12 / 2008$ & FED & Reduziu a taxa fed funds de $1 \%$ para algo entre $0 \%$ e $0,25 \%$ \\
\hline 08/01/2009 & BoE & $\begin{array}{l}\text { O Banco Central da Inglaterra reduziu a taxa básica de juros em } \\
0,5 \text { p.p. para } 1,5 \% \text { ao ano. }\end{array}$ \\
\hline $15 / 01 / 2009$ & BCE & $\begin{array}{l}\text { O Banco Central Europeu diminui a taxa de juro aplicável às } \\
\text { operações principais de refinanciamento em } 0,5 \text { p.p. para } 2 \% \text {. }\end{array}$ \\
\hline
\end{tabular}

Fonte: Chailloux, Gray, Klüh, Shimizu, Stella (2008), BACEN (2008) e sites de notícias. Elaboração: IPEA (2009a). 
Em linhas gerais, conforme o IPEA (2009a), os bancos centrais adotaram medidas voltadas tanto para a adequação da liquidez do sistema financeiro e alterações nas alíquotas e regras de recolhimento de compulsório, quanto reduções na taxa básica de juros.

Os países desenvolvidos encontram-se numa situação denominada por Keynes (1982) como "armadilha de liquidez", onde os esforços de estímulo da atividade econômica surtem pouco efeito por meio de medidas de política monetária, restando como opção ao incentivo do nível de emprego e renda, as políticas fiscais.

Em função do acirramento das incertezas e da insuficiência das medidas de resgate adotadas até o momento, o FED, o congresso e o Tesouro norte-americanos organizaram uma série de pacotes de estabilização do sistema financeiro, como demonstra os dados do IPEA (2009a):

- US\$ 850 bilhões destinados a aquisição de créditos "podres" das instituições financeiras insolventes, sendo que aproximadamente $30 \%$ será destinado à compra de ações de bancos (outubro de 2008).

- Elevação de US\$100 mil para US\$250 mil do limite de depósitos bancários que passam a ser garantidos pelo governo.

- Corte de impostos para a classe média e incentivos aos pequenos empresários.

- Plano de resgate do Citigroup com financiamento de cerca de US $\$ 306$ bilhões em empréstimos e títulos e investimento de cerca de US\$20 bilhões no grupo (novembro de 2008).

- Plano de resgate das montadoras. A General Motors e a Chrysler foram contempladas com cerca de US\$ 14 bilhões após árduo processo no legislativo federal dos EUA. A Ford desistiu de sua demanda inicial (dezembro de 2008).

De acordo com Tavares (2009), a posse do novo presidente dos EUA, Barack Obama, trouxe a proposta de combate à crise em diversas vertentes: financeira, fiscal; infra-estrutura e políticas sociais, por meio da Lei de Recuperação e de Reinvestimento Americanos (ARRA) aprovada em fevereiro de 2009. O pacote fiscal 
previu inicialmente US\$787 bilhões em transferências para estados e municípios, gastos em infra-estrutura e ciência, auxílio aos segmentos sociais desfavorecidos, saúde, educação e treinamento de mão-de-obra, energia e, principalmente, renúncias fiscais. Desta forma, o déficit fiscal da União deverá passar de cerca de US\$ 1 trilhão em 2008 para US\$ 1,7 trilhão em 2009, com tendência ainda progressiva para 2010.

Quanto ao setor financeiro, o novo governo norte-americano anunciou um Plano de Estabilidade Financeira (FSP) com um vultoso montante de recursos que serão divididos em três novos instrumentos, como detalha Tavares (2009):

- um fundo fiduciário para reforçar o capital dos bancos além dos US $\$ 350$ bilhões anteriormente aprovados.

- um fundo de participação público-privado para leiloar os títulos "tóxicos" de bancos a investidores privados, com uma participação acionária minoritária do Tesouro.

- uma linha (facility) para a aquisição de dívida securitizada, nova e boa para recompor a liquidez das instituições financeiras e estabilizar a oferta de crédito.

Os esforços realizados começam a surtir efeito em 2009. O mercado financeiro internacional, apesar de ainda muito debilitado, segue tendência de estabilização.

[...] ações dos bancos norte-americanos, que haviam sofrido severa desvalorização e, em alguns casos, chegaram a perder mais de $90 \%$ do valor de mercado. Ações do Wells Fargo, Citibank e Bank of America registram desde março valorizações próximas de $300 \%$. De modo geral, as bolsas têm tido comportamento de recuperação ao redor do mundo. Os índices Dow Jones (Nova York) e Ibovespa (São Paulo) tiveram altas expressivas no mês de abril, de 7,3\% e 15,5\%, respectivamente.(SENADO FEDERAL, 2009, p.2)

As ações de estímulo à economia não se limitam aos Estados Unidos, abrangendo diversos países também afetados pela crise, afinal, todas as economias do G-7 (Estados Unidos, Japão, Alemanha, Reino Unido, França, Itália e Canadá) estão formalmente em recessão. No oriente, a recessão também atinge fortemente os países do leste da Ásia devido à desaceleração industrial e do comércio exterior da China. 
O Instituto Nacional de Pesquisa Econômica (National Bureau of Economic Research) define recessão como um declínio significativo na atividade econômica disseminado na economia, com duração maior do que apenas poucos meses. Diversos economistas consideram esta duração como dois trimestres seguidos de queda no PIB. Na Tabela 2 abaixo, pode-se observar este quadro de forte retração do PIB entre os anos de 2007 a 2009, apesar de os números fornecidos pelo FMI (Fundo Monetário Internacional) serem considerados otimistas:

Tabela 2: Crescimento real do PIB por habitante: Países desenvolvidos (\%)

\begin{tabular}{|c|c|c|c|c|c|c|c|c|c|c|c|c|}
\hline & $\begin{array}{r}\text { Médias } \\
\text { an }\end{array}$ & $\begin{array}{l}\text { obre dez } \\
\text { ss }\end{array}$ & \multirow{2}{*}{2000} & \multirow{2}{*}{2001} & \multirow{2}{*}{2002} & \multirow{2}{*}{2003} & \multirow{2}{*}{2004} & \multirow{2}{*}{2005} & \multirow{2}{*}{2006} & \multirow{2}{*}{2007} & \multirow{2}{*}{2008} & \multirow{2}{*}{2009} \\
\hline & $1990-99$ & $2000-09$ & & & & & & & & & & \\
\hline Países desenvolvidos & 2,0 & 1,6 & 3,3 & 0,5 & 1,0 & 1,3 & 2,6 & 1,9 & 2,4 & 1,9 & 0,9 & $-0,1$ \\
\hline Estados Unidos & 1,9 & 1,2 & 2,5 & $-0,3$ & 0,6 & 1,5 & 2,7 & 2,0 & 1,8 & 1,1 & 0,6 & $-0,9$ \\
\hline Zona do euro ${ }^{4}$ & $\ldots$ & 1,3 & 3,5 & 1,5 & 0,4 & 0,2 & 1,4 & 1,1 & 2,2 & 1,9 & 0,8 & $-0,2$ \\
\hline Alemanha & 1,7 & 1,4 & 3,1 & 0,9 & $-0,1$ & $-0,2$ & 1,2 & 0,8 & 3,2 & 2,6 & 1,9 & 0,1 \\
\hline França & 1,5 & 1,1 & 3,2 & 1,2 & 0,3 & 0,4 & 1,8 & 1,3 & 1,6 & 1,6 & 0,3 & $-0,4$ \\
\hline Itália & 1,4 & 0,6 & 3,4 & 1,5 & 0,2 & $\ldots$ & 1,5 & $-0,5$ & 1,2 & 0,7 & $-0,8$ & $-0,9$ \\
\hline Espanha & 2,5 & 1,6 & 4,2 & 2,5 & 1,2 & 1,4 & 1,6 & 1,9 & 2,3 & 1,8 & $-0,1$ & $-1,0$ \\
\hline Japão & 1,2 & 1,4 & 2,7 & $-0,1$ & 0,1 & 1,2 & 2,7 & 1,9 & 2,4 & 2,1 & 0,7 & 0,5 \\
\hline Reino Unido & 1,9 & 1,9 & 3,6 & 2,1 & 1,7 & 2,4 & 2,3 & 1,4 & 2,3 & 2,5 & 0,7 & $-0,3$ \\
\hline Canadá & 1,3 & 1,5 & 4,3 & 0,7 & 1,8 & 0,9 & 2,1 & 1,9 & 2,1 & 1,6 & $-0,3$ & 0,2 \\
\hline $\begin{array}{l}\text { Outros países } \\
\text { desenvolvidos }\end{array}$ & 3,2 & 3,0 & 5,0 & 0,5 & 3,2 & 1,9 & 4,2 & 3,3 & 3,7 & 3,9 & 2,4 & 1,7 \\
\hline $\begin{array}{l}\text { Principais países } \\
\text { desenvolvidos }\end{array}$ & 1,7 & 1,3 & 3,0 & 0,4 & 0,6 & 1,2 & 2,4 & 1,7 & 2,1 & 1,6 & 0,7 & $-0,4$ \\
\hline $\begin{array}{l}\text { Novas economias } \\
\text { industriais da Ásia }\end{array}$ & 5,0 & 4,1 & 6,8 & 0,4 & 5,0 & 2,9 & 5,5 & 4,4 & 5,0 & 5,0 & 3,4 & 2,7 \\
\hline
\end{tabular}

Fonte: FMl (2009), com adaptações.

Tal como os países ricos, a América Latina tem sentido os efeitos da crise. Tavares (2009) lembra que no final de 2007 os países latino-americanos vinham crescendo em média 4\%, e o Brasil, 5,8\% nos três primeiros trimestres de 2008. 0 governo brasileiro acreditava que a onda avassaladora que atingia os países desenvolvidos não passaria de uma "marolinha" em solo brasileiro. Entretanto, a quebra do Lehman Brothers promoveu um contágio imediato aos mercados

\footnotetext{
${ }^{4}$ A zona do euro é formada por Alemanha, Áustria, Bélgica, Chipre, Eslováquia, Eslovênia, Espanha, Finlândia, França, Grécia, Holanda, Irlanda, Itália, Luxemburgo, Malta e Portugal. A União Européia inclui, além destes, Bulgária, Dinamarca, Reino Unido, República Tcheca, Suécia, Polônia, Hungria, Romênia, Estônia, Lituânia e Letônia e deverá registrar contração do PIB de 4,2\% em 2009 e de 0,4\% em 2010.
} 
emergentes e em desenvolvimento, principalmente, por meio da redução de crédito e do comércio exterior de commodities, cujos preços caíram cerca $50 \%$.

O choque financeiro foi de tal força que o indicador de risco do EMBI latinoamericano aumentou 438 pontos básicos, voltando a níveis absolutos que não se viam desde os anos da crise argentina. Em 12 de dezembro o Equador anunciou o repúdio da sua dívida externa. A Argentina e a Venezuela estão com riscos altíssimos, equivalentes a níveis de default, e o México para evitar uma crise de pagamentos solicitou U\$40 bilhões ao FMI em começo de abril de 2009. O mesmo acaba de ocorrer com a Colômbia. Os mercados de capitais continuam fechados. [...] As expectativas de crescimento médio do PIB para a América Latina tornaram-se negativos para 2009, embora no Brasil as estimativas do Governo ainda sejam ligeiramente positivas. (TAVARES, 2009, p.10)

O Global Monitoring Report 2009: a Development Emergency (GMR) -

Relatório sobre Monitoramento Global 2009: Uma Emergência para o Desenvolvimento - produzido pelo Banco Mundial em parceria com o FMI, informa que a crise afetará todos os países em desenvolvimento nos próximos dois anos, devido à contração de volumes da exportação, queda dos preços, redução do ritmo da demanda interna, diminuição das remessas e do investimento estrangeiro, acesso reduzido ao financiamento e encolhimento das receitas. Prevê-se que o crescimento do mundo em desenvolvimento caia para 1,6\% em 2009, em comparação com a média de $8,1 \%$ em 2006 e 2007. A preocupação reside na estimativa do Banco Mundial de que cada $1 \%$ de redução na taxa de crescimento econômico, retém 20 milhões de pessoas na condição de pobreza. Além disso, projeta-se que a produção global se contraia a 1,3\% este ano.

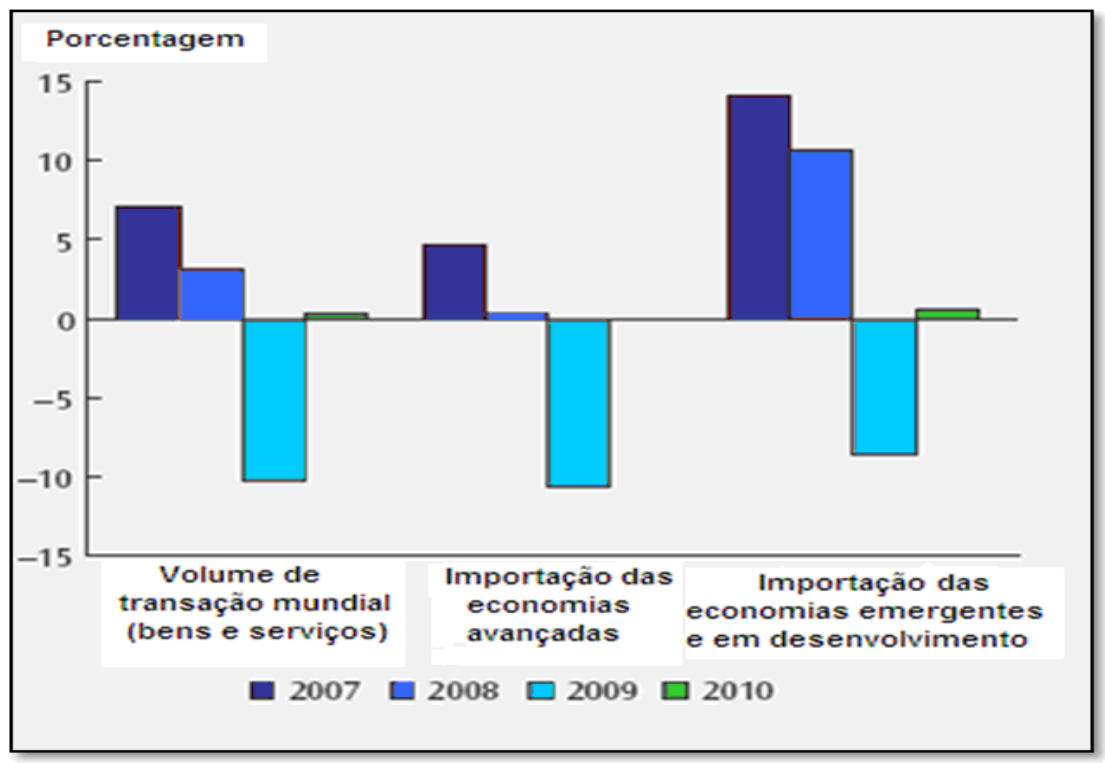

Ilustração 7: Comércio internacional de bens e serviços Fonte: FMI, GMR (2009), com adaptações. 
Considerando o cenário exposto, Mota (2009) enfatiza que, de maneira geral, as ações governamentais devem se direcionar no sentido de evitar o aprofundamento da crise e atenuar seus efeitos econômicos sobre a atividade produtiva e o nível de emprego estimulando, assim, a recuperação econômica. Cada um desses objetivos, no entanto, requer medidas de natureza distinta tanto na área monetária (reduzindo juros, expandindo o meio circulante e, às vezes, garantindo a liquidez de instituições financeiras), como na área fiscal (projetos de gastos em infraestrutura e isenção fiscal por setores). A Tabela 3, subseqüente, apresenta ações comuns a alguns países latino-americanos:

Tabela 3: Políticas e ações de governo em países selecionados.

\begin{tabular}{|c|c|c|c|c|c|c|c|}
\hline \multicolumn{2}{|c|}{ Políticas e ações específicas } & $\begin{array}{c}\text { Argentin } \\
a\end{array}$ & Brasil & Paraguai & $\underset{i}{\text { Urugua }}$ & Chile & México \\
\hline \multirow{2}{*}{$\begin{array}{c}\text { Monetária e } \\
\text { Financeira }\end{array}$} & $\begin{array}{l}\text { Redução ou } \\
\text { flexibilização das } \\
\text { exigências de } \\
\text { reservas }\end{array}$ & $\mathrm{X}$ & $\mathrm{X}$ & $\mathrm{x}$ & & $\mathrm{x}$ & \\
\hline & $\begin{array}{l}\text { Oferta de liquidez } \\
\text { em moeda } \\
\text { doméstica }\end{array}$ & $\mathrm{X}$ & $\mathrm{X}$ & $\mathrm{X}$ & $\mathrm{X}$ & $\mathrm{x}$ & $\mathrm{x}$ \\
\hline \multirow[b]{2}{*}{ Fiscal } & $\begin{array}{l}\text { Redução de tributos } \\
\text { ou aumento de } \\
\text { subsídios }\end{array}$ & $\mathrm{X}$ & $\mathrm{X}$ & & & & \\
\hline & $\begin{array}{c}\text { Aumento ou } \\
\text { antecipação de } \\
\text { investimento em } \\
\text { infra-estrutura }\end{array}$ & $\mathrm{X}$ & $x$ & $\mathrm{X}$ & $\mathrm{X}$ & $\mathrm{x}$ & $\mathrm{x}$ \\
\hline \multirow{5}{*}{$\begin{array}{l}\text { Comércio } \\
\text { Externo }\end{array}$} & $\begin{array}{c}\text { Oferta de liquidez } \\
\text { em moeda } \\
\text { estrangeira }\end{array}$ & $\mathrm{X}$ & $\mathrm{x}$ & & $\mathrm{X}$ & $\mathrm{X}$ & \\
\hline & $\begin{array}{l}\text { Aumento de tarifas } \\
\text { ou restrições às } \\
\text { importações }\end{array}$ & $\mathrm{X}$ & & & & & \\
\hline & Redução de tarifas & $x$ & & & & & $x$ \\
\hline & $\begin{array}{c}\text { Financiamento de } \\
\text { exportações }\end{array}$ & $\mathrm{x}$ & $\mathrm{x}$ & $x$ & $\mathrm{X}$ & $x$ & \\
\hline & $\begin{array}{c}\text { Linhas de crédito } \\
\text { com BID e Banco } \\
\text { Mundial }\end{array}$ & & & $\mathrm{X}$ & & & \\
\hline \multirow{5}{*}{ Setoriais } & Moradia & & $\mathrm{x}$ & & $\mathrm{X}$ & $\mathrm{x}$ & \\
\hline & Saneamento & $\mathrm{X}$ & $\mathrm{x}$ & & $\mathrm{X}$ & $\mathrm{x}$ & $\mathrm{x}$ \\
\hline & Agricultura & & $X$ & & $x$ & & \\
\hline & Turismo & & & & $x$ & & \\
\hline & Indústria & $\mathrm{X}$ & $\mathrm{X}$ & & $x$ & & \\
\hline \multirow{2}{*}{$\begin{array}{l}\text { Trabalhista } \\
\text { s e Sociais }\end{array}$} & $\begin{array}{l}\text { Ativação do } \\
\text { emprego }\end{array}$ & $x$ & $\mathrm{X}$ & & & $\mathrm{x}$ & $\mathrm{x}$ \\
\hline & Programas Sociais & & $\mathrm{X}$ & $\mathrm{X}$ & & & \\
\hline
\end{tabular}

Fonte: Cepal, elaboração IPEA. 
A turbulência na economia internacional afeta diferenciadamente os países com menor grau de desenvolvimento, atingindo mais vigorosamente aqueles de natureza primário-exportadora, geralmente mais dependente da demanda internacional. Por esta razão, os efeitos da crise para os países em desenvolvimento no médio e longo prazo dependem da duração e intensidade dos efeitos da crise financeira nos países ricos.

A compreensão da atuação das instituições brasileiras perante a crise parte da análise da abrangência e profundidade que a economia brasileira foi atingida. Esta análise será realizada na próxima seção com base em dados macroeconômicos e nas entrevistas realizadas.

\subsection{Os Impactos da Crise: Dados Macroeconômicos Brasileiros}

Em setembro de 2008, a conjuntura internacional sofreu forte abalo com o agravamento da crise financeira. A queda dos preços das commodities e da demanda mundial se deu em resposta ao aumento da aversão global ao risco. Conforme a Carta de Conjuntura do IPEA de março de 2009, os primeiros reflexos da crise no Brasil se manifestaram através da diminuição do fluxo de capitais em geral e das linhas de crédito externo, prejudicando as operações de investimento para as atividades exportadoras. Os bancos, seguindo a tendência mundial, assumiram uma posição mais avessa ao risco, reduzindo a concessão de crédito.

Esta aversão fica bem evidente quando o spread bancário é analisado: "em relação à média de janeiro a agosto de 2008, o aumento do spread foi de $28,3 \%$ em janeiro de 2009" (IPEA, 2009a, p.29), Apesar da taxa de inadimplência se manter a mesma de janeiro de 2007.

Neste contexto a taxa de crescimento das operações para pessoa jurídica passou a diminuir consideravelmente a partir de novembro de 2008, como demonstra a llustração $8^{5}$, na página seguinte:

\footnotetext{
${ }^{5}$ Considerando variações dos saldos em finais de períodos entre 12 meses.
} 


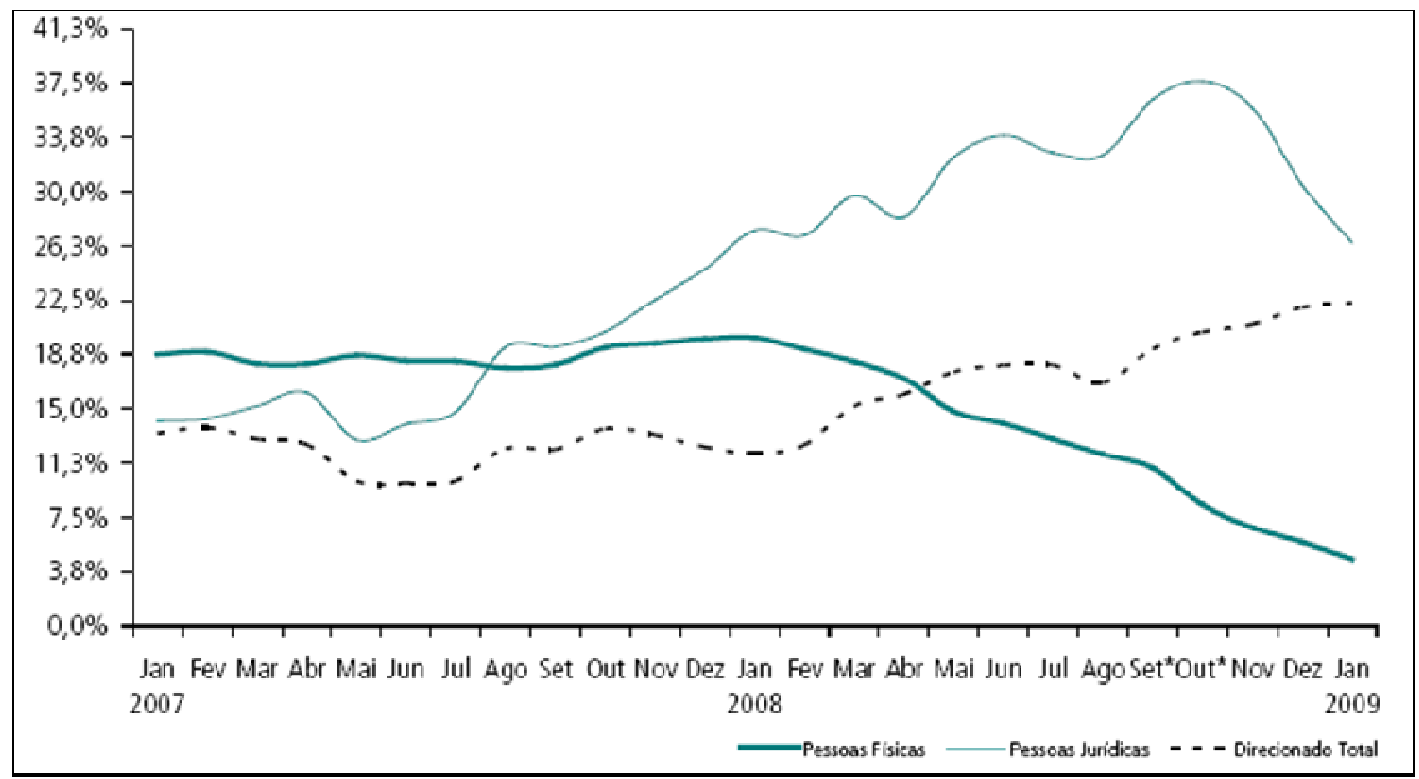

Ilustração 8: Taxas reais de crescimento das operações de crédito (variações dos saldos em finais de períodos entre 12 meses)

Fonte: Banco Central. Elaboração: IPEA/DIMAC/GAP.

O fator crítico de redução do crédito para pessoa jurídica foi a queda de 70,35\%, em 2008, dos repasses externos, conforme IPEA (2009a). Em busca de amenizar este quadro, o governo vem realizando consecutivos cortes na taxa básica de juros, SELIC ${ }^{6}$, como pode ser visualizado na llustração 9:

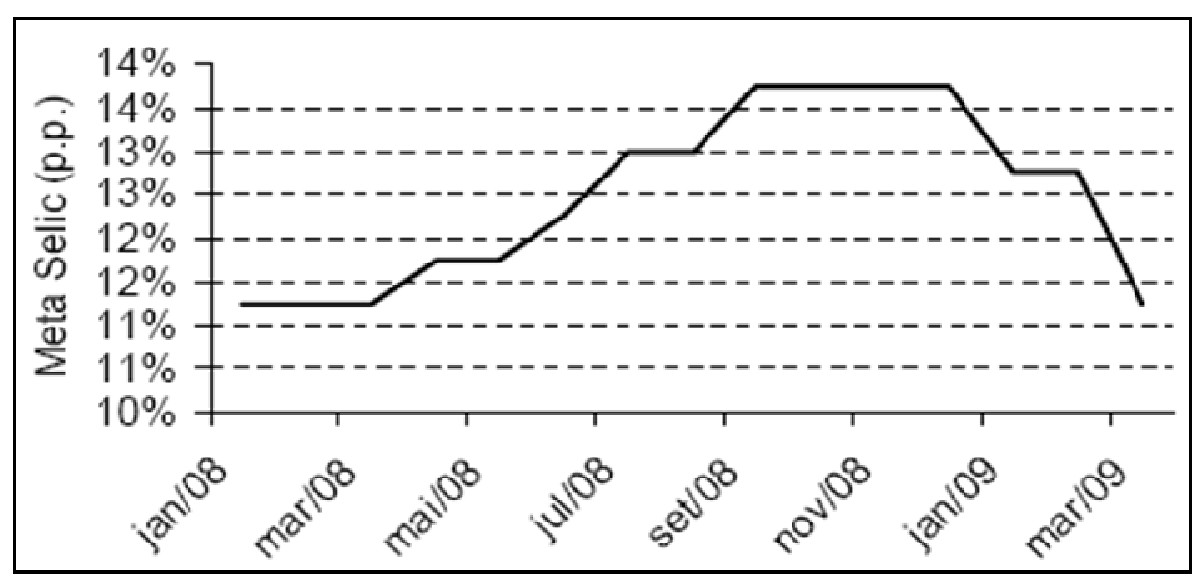

Ilustração 9: Evolução da taxa SELIC 2008/2009

Fonte: SENADO FEDERAL (2009)

Tendo em vista as perspectivas de domínio da inflação em relação à trajetória de metas, o Comitê de Política Monetária (Copom), em reunião do dia 10 de junho

\footnotetext{
${ }^{6}$ A taxa SELIC - Sistema Especial de Liquidação e Custódia é a taxa média ponderada pelo volume das operações de financiamento por um dia, lastreadas em títulos públicos federais e realizadas no SELIC, na forma de operações compromissadas. É a taxa básica utilizada como referência pela política monetária (Sumário Metodológico do Banco Central).
} 
de 2009, decidiu reduzir a taxa Selic para 9,25\% a.a, um valor inédito nos últimos 10 anos.

Esta é uma das medidas do Poder Executivo para atenuar os efeitos das reduções das linhas de crédito externas, incentivando o crédito doméstico. $A$ consultora legislativa do Senado, área de orçamento, Maria Liz Roarelli, aborda este aspecto em sua entrevista:

[...]o crédito doméstico representa $80 \%$ do total, só $20 \%$ do crédito é externo. Então, $20 \%$ é muita coisa? É, mas se for observar o total, ainda tinha $80 \%$ para poder manobrar até a economia restaurar seus níveis anteriores de credibilidade, e tanto teve que o Brasil conseguiu. O governo está emprestando mais, abrindo mais linhas de crédito no BNDES e na Caixa Econômica, pra manter os níveis de investimento privado e de consumo também.(ROARELLI, 2009, Apêndice D)

Outra medida foi o fornecimento de linhas de crédito em moeda estrangeira com a utilização das reservas internacionais administradas pelo Banco Central do Brasil, além da diminuição dos depósitos compulsórios (redução de $\mathrm{R} \$ 81$ bilhões $^{7}$ ) auxiliando na recomposição da liquidez das instituições financeiras e incremento no mercado interno de crédito.

Com efeito, em janeiro de 2007 a concessão de crédito doméstico ao setor privado atingia $30 \%$ do PIB. Em janeiro de 2008 , chegou a $34 \%$ do PIB e agora recentemente, em janeiro de 2009 , esse indicador chega à marca de $40,3 \%$ do PIB, com cerca de um terço dessa expansão direcionada ao setor privado industrial.(TEIXEIRA, 2009, p.14)

Quanto à produção industrial no Brasil, Teixeira (2009) acrescentou ainda que a assustadora retração compreendida no $4^{\circ}$ trimestre de 2008 foi de $18,7 \%{ }^{8}$, queda sem precedentes desde janeiro de 1995, indicada na llustração 10, abaixo:

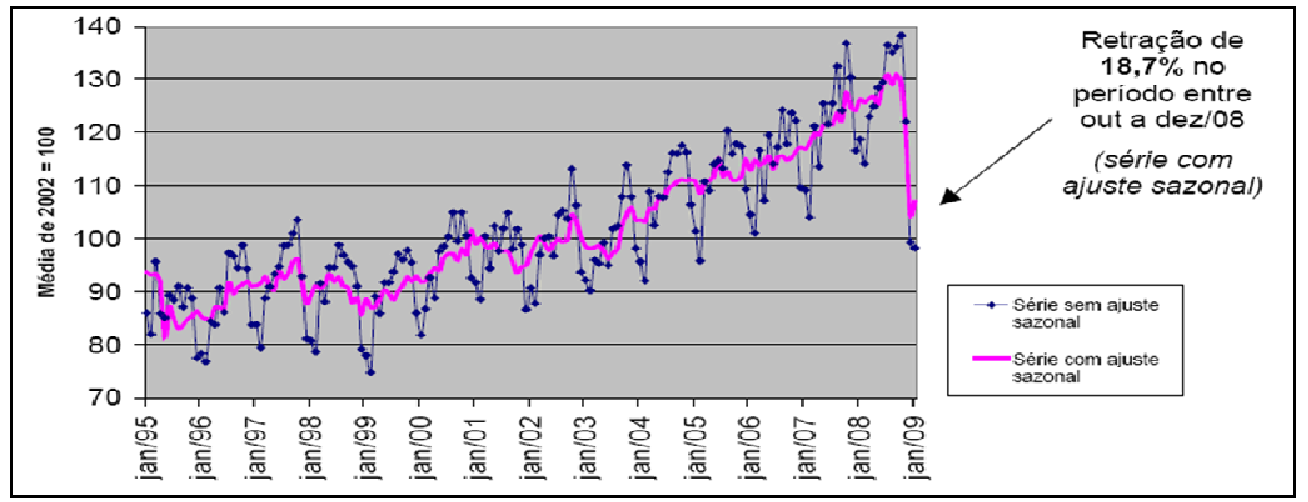

Ilustração 10: Evolução da Produção Industrial no período de jan/95 a jan/09 Fonte: Pesquisa Industrial Mensal - IBGE.

\footnotetext{
${ }^{7}$ Dado da Carta de Conjuntura do IPEA - março de 2009.

${ }^{8}$ Série com ajuste sazonal.
} 
Diversos setores da economia foram contagiados pela crise, entretanto, o pior desempenho ficou por conta da indústria, em especial de bens duráveis (automóveis, camionetas e utilitários). A Tabela 4 traduz o anteriormente exposto em números :

Tabela 4: PIB: taxa real de crescimento trimestral e acumulado no ano (\%)

\begin{tabular}{|c|c|c|c|c|c|}
\hline & \multicolumn{4}{|c|}{2008} & \multirow{2}{*}{$\frac{\text { Variação anual }}{2008}$} \\
\hline & $\mathbf{I}$ & II & III & IV & \\
\hline PIB pm & 6,1 & 6,2 & 6,8 & 1,3 & 5,1 \\
\hline Agropecuária & 3,8 & 9,3 & 6,4 & 2,2 & 5,8 \\
\hline Indústria & 6,9 & 5,7 & 7,1 & $-2,1$ & 4,3 \\
\hline Serviços & 5,2 & 5,4 & 5,9 & 2,5 & 4,8 \\
\hline Consumo - total & 6,3 & 5,5 & 7,1 & 3,0 & 5,4 \\
\hline FBFC & 15,4 & 16,6 & 19,7 & 3,8 & 13,8 \\
\hline Exportação & $-2,3$ & 4,9 & 2,0 & $-7,0$ & $-0,6$ \\
\hline Importação & 18,8 & 26,0 & 22,8 & 7,6 & 18,5 \\
\hline PIB pm var. dessaz. (\%) & 1,6 & 1,6 & 1,7 & $-3,6$ & \\
\hline
\end{tabular}

Fonte: IPEA(2009b)

Por outro lado, as expectativas apontam para uma rápida recuperação em 2010, saindo de um crescimento negativo da produção de 1,8\% em 2009, para +4\%, percentagem razoável, considerando a variação anual de 2008 (apresentada na tabela 4).

Os índices de confiança apontam para um estado de melhoria das expectativas, principalmente na indústria, corroborando a tese de que a economia pode estar entrando na fase de recuperação. Assim como ocorre com os indicadores de produção, os índices de confiança ainda estão em níveis abaixo do que vigiam no final de 2008. (SENADO, 2009, p.10)

A Carta de Conjuntura do IPEA (2009) explica que a referida queda no nível de confiança dos consumidores está intimamente associada ao desempenho do mercado de trabalho. O aumento da taxa de desemprego, somado às dificuldades de acesso ao crédito, geram um comportamento de precaução nos consumidores que evitam novas aquisições de bens, especialmente aqueles que geralmente são adquiridos por intermédio de financiamento.

Acerca deste tópico, o economista-chefe do grupo de estudos da crise do IPEA, Milko Matijascic, comenta: 
Essa retração já se apresentou no quarto trimestre de 2008 e no primeiro trimestre desse ano, e provavelmente, se não houver uma reação, 0 segundo trimestre terá um nível de atividades ainda muito claudicante, ou pelo menos muito restrito do ponto de vista do seu desempenho. Ainda possivelmente será um desempenho pior do que o do segundo trimestre do ano passado. Mas considerando a envergadura da crise internacional, considerando o enorme volume de dificuldades envolvidas e principalmente o enorme descolamento da massa financeira em relação aos bens e ativos disponíveis e para transação da economia, a economia brasileira pode-se dizer que está se saindo relativamente bem. Mas isso não elimina o fato de que se vai ter retração econômica, e essa retração econômica, do ponto de vista do orçamento, vai causar dificuldades. (MATIJASCIC, 2009, Apêndice E)

No mês de janeiro de 2009, época em que normalmente há aumento do desemprego, observa-se (llustração 11) a ocorrência de uma variação maior do que aquela que usualmente ocorreria por motivos sazonais.

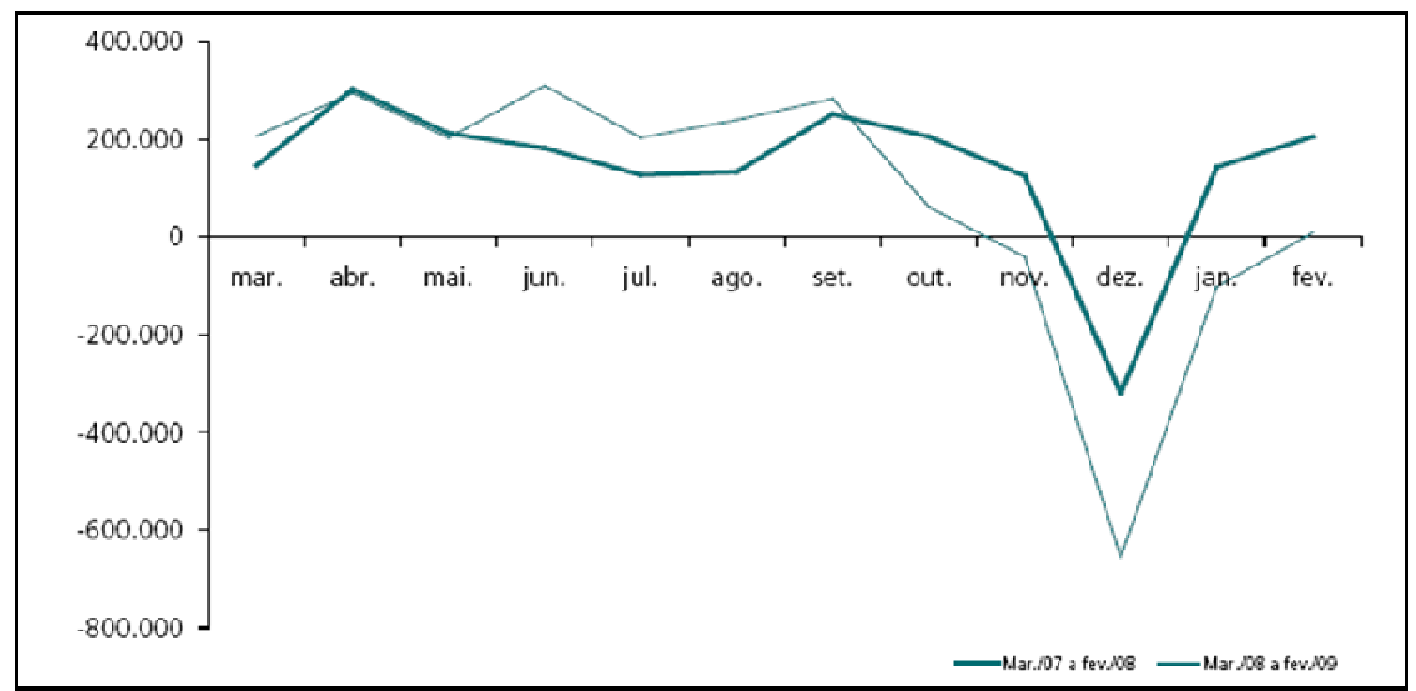

Ilustração 11: Saldo de Emprego 2007-2008.

Fonte: CAGED . Elaboração: IPEA (2009).

Segundo dados do IPEA (2009b) sobre os impactos da crise sobre o emprego no Brasil, até outubro de 2008 , houve uma acelerada criação de empregos com carteira assinada, refletindo tanto o crescimento da produção quanto a formalização dos vínculos. Contudo, no período entre novembro de 2008 e março de 2009 foi registrado saldo negativo tanto nas regiões metropolitanas ${ }^{9}$, de quase 167 mil postos de trabalho, quanto nas regiões não-metropolitanas 525 mil, recordes negativos para o período 1999/2009. Quando o mês de fevereiro de 2009 é analisado isoladamente a variação é positiva nas duas áreas, apesar de o resultado ainda ser o pior dos últimos nove anos.

\footnotetext{
${ }^{9}$ As regiões metropolitanas incluídas aqui são as mesmas usadas pelo Ministério do Trabalho e Emprego: Belém, Fortaleza, Recife, Salvador, Rio de Janeiro, São Paulo, Curitiba e Porto Alegre.
} 
Realizando uma análise por setor, a Carta de Conjuntura do IPEA (2009) informa que comércio continua sendo o maior empregador com 19,2\% dos trabalhadores, na média de 2008. Em segundo lugar, está o setor de serviços, empregando 17,2\%, seguido da indústria $(17,0 \%)$ e da administração pública $(15,9 \%)$, em quarto lugar. Apesar de o comércio comportar a maior parcela de trabalhadores, foi o setor que apresentou a menor taxa de expansão no período póscrise $^{10}$, enquanto o quarto maior empregador, a administração pública, apresentou maior crescimento na comparação, como demonstra a llustração 12, a seguir:

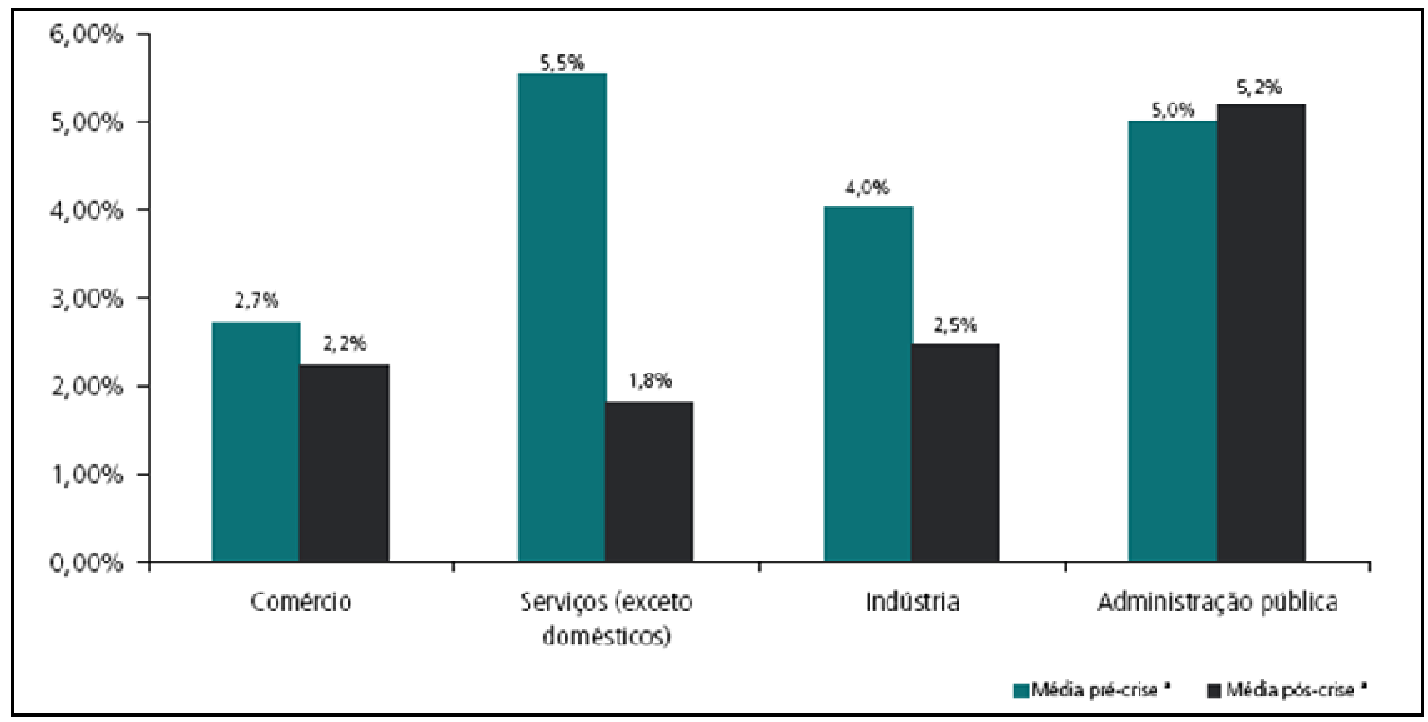

Ilustração 12: Taxa de variação na ocupação - 4 maiores empregadores na média de $2008^{11}$. Fonte: IBGE. Elaboração: IPEA/Dimac/GAP.

É interessante observar que a administração, no que se refere aos indicadores de ocupação, não se abalou como os demais setores, representado, assim, um porto seguro de renda, que acaba desempenhando um papel anticíclico diante das implicações geradas pela crise no mercado de trabalho.

Por outro lado, o assessor econômico do MPOG, Cristiano Portugal, criticou fortemente a questão das despesas com pessoal:

Do lado da despesa falta ainda criar uma rédia mais forte, colocar o controle
sobre a despesa de pessoal, apesar de que essa despesa vinha caindo em
proporção do PIB nos últimos anos. Agora que houve um processo de
renegociação com várias carreiras, ela retomou o crescimento. Acho que é
nesse momento que a gente pode lançar mão de um projeto de lei para
controlar o gasto. (PORTUGAL, 2009, apêndice C)

10 A média pré-crise corresponde ao período de janeiro de 2008 a agosto de 2008, com suas taxas de variação em relação ao mesmo mês do ano anterior. A média na crise, analogamente, trata de setembro de 2008 a janeiro de 2009.

${ }^{11}$ Médias do mês em relação ao mesmo mês do ano anterior 
Além dos fatores já elencados, diversas empresas que adotaram posições de risco associadas à trajetória de apreciação cambial, também foram seriamente afetadas pela repentina depreciação da taxa de câmbio. Segundo o Relatório de Estabilidade Financeira do Banco Central do Brasil (2009), a desvalorização cambial do $4^{\circ}$ trimestre de 2008 tornou o real uma das moedas que mais se desvalorizou perante o dólar norte-americano. O saldo total em câmbio contratado dos últimos 12 meses, até fevereiro de 2009, foi de US\$ 4,05 bilhões negativos, ou seja, a compra de dólares superou a venda. A referida depreciação da taxa cambial pode ser claramente observada na llustração 13 seqüente:

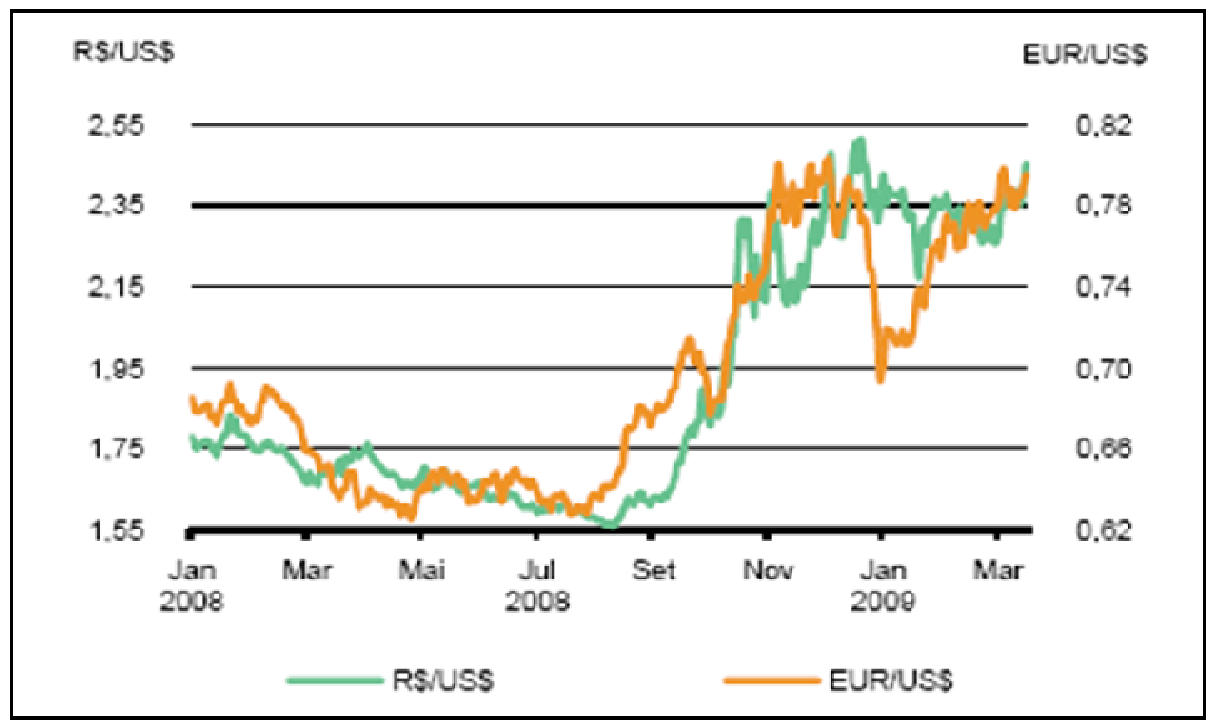

Ilustração 13: Taxa de Câmbio Fonte: BCB (2009b)

Por outro lado, "parece haver consenso entre a maioria dos analistas financeiros a respeito de uma tendência a movimentos menos bruscos no mercado de câmbio, ao contrário do que aconteceu nos últimos meses de 2008" (IPEA, 2009a p.32). Esta tendência é reforçada pela queda na taxa de câmbio em junho de 2009, quando a média das cotações diárias, até o dia 18, alcançou a proporção de $R \$$ $1,97^{12}$ por US\$1. O Brasil vem mantendo o nível de suas reservas cambiais, entretanto, é importante destacar que o atual cenário internacional ainda dificulta as previsões de longo prazo para o câmbio. Contudo, sobre este ponto, o coordenador geral de contabilidade do Tesouro Nacional, Paulo Henrique Feijó, apresenta argumentos positivos em sua entrevista:

\footnotetext{
${ }^{12}$ Base de valores referentes à tabela de cotações de câmbio do Banco Central do Brasil.
} 
[...] os efeitos sobre a política cambial, ou seja, a questão do dólar, onde o investidor está encontrando no Brasil, mesmo com todo o impacto da crise, um porto seguro. Acho que ajudou muito o país a ser um país de grau de investimento. No ano passado as agências de rating acabaram avaliando 0 país como esse porto seguro. (FEIJÓ, 2009, apêndice E)

Os principais impactos da crise internacional sobre a balança comercial ${ }^{13}$ brasileira foram a rápida deterioração de seus termos de troca e a queda proporcionalmente maior do montante exportado em relação ao importado.

Após registrar um déficit de US\$524 milhões no primeiro mês de 2009 , a balança comercial brasileira apresentou superávit de US\$1,8 bilhão em fevereiro. Essa inversão nos resultados mensais elevou o saldo comercial em 12 meses a US $\$ 24,2$ bilhões, provocando a interrupção de sua trajetória contínua de quedas, desde maio de 2008. Assim, se, por um lado, a balança comercial exibiu um resultado bem inferior ao observado nos 12 meses até fevereiro de 2008 (US\$ 36,4 bilhões), por outro, seu desempenho mostrou-se próximo ao registrado durante o ano de 2008 (US\$ 24,8 bilhões).(IPEA, 2009a p.25)

Neste ensejo, a dados preliminares divulgados pelo Ministério do Desenvolvimento, Indústria e Comércio Exterior (MDIC) apontam superávit de US\$ 3,7 bilhões em abril. Caso este resultado se perpetue durante o ano de 2009, a projeção anual de saldo da balança comercial em torno de US\$ 12 bilhões (llustração14) poderá se concretizar:

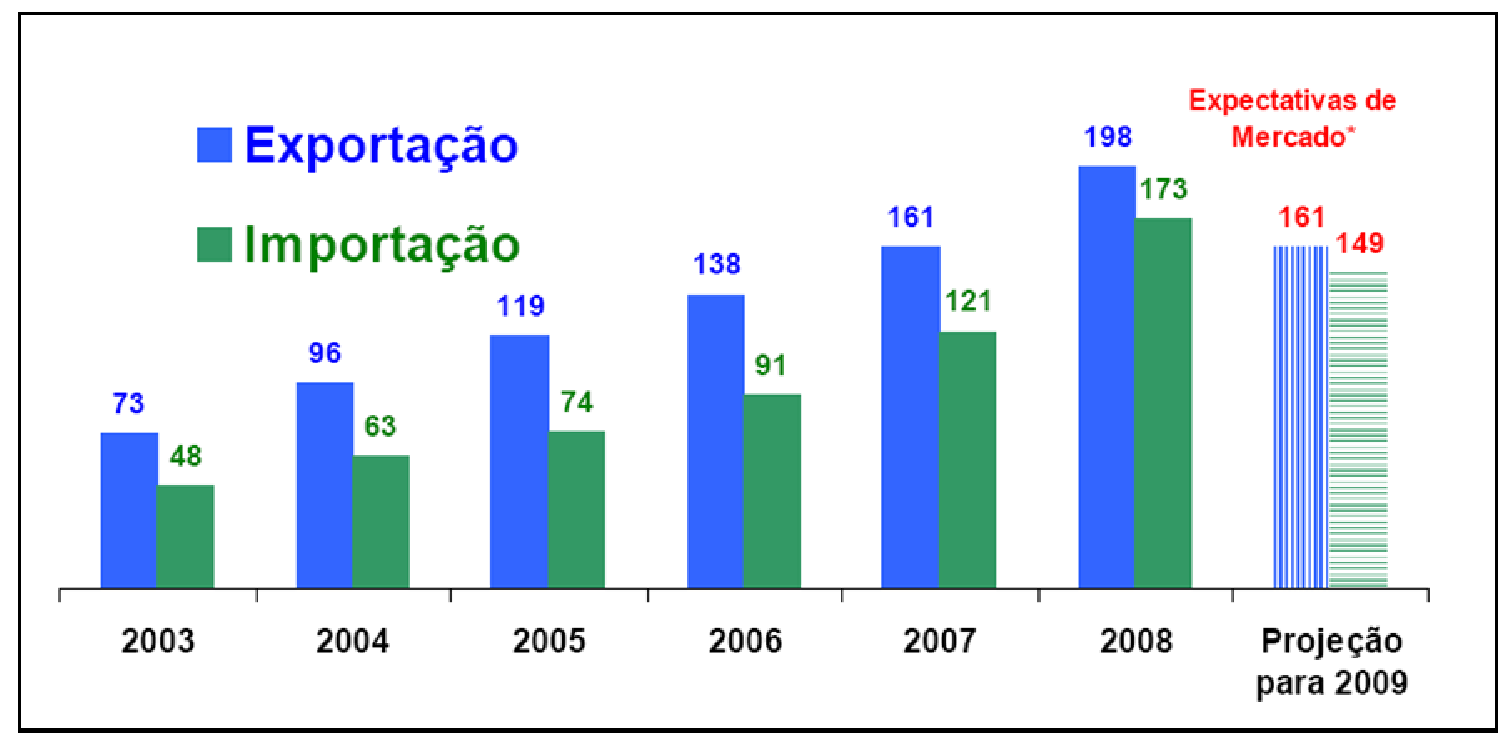

Ilustração 14 :Balança Comercial (em US\$bi)

Fonte: MDIC e BCB. Elaboração: MF/SPE

13 "O balanço comercial corresponde ao saldo das exportações sobre as importações, as primeiras computadas com sinal positivo [crédito], as segundas com sinal negativo [débito], [...] computadas pelo seu valor FOB, isto é, pelo seu valor de embarque, não incluídos os fretes e seguros." (SIMONSEN; CYSNE, 1995, p.80) 
Teixeira (2009) destaca que a corrente de comércio ${ }^{14}$ brasileira representa um valor correspondente a cerca de $26 \%$ do $\mathrm{PIB}$, percentagem relativamente baixa quando comparada aos demais países do BRIC: a China comporta uma corrente de comércio com valor equivalente a $71 \%$ de seu PIB, a Rússia, com 54\% e a Índia, com $45 \%$.

A respeito da balança comercial, Milko Matijascic, do IPEA, apresentou um posicionamento único, em relação às demais fontes pesquisadas:

[...] um ponto a enfatizar é que a queda de atividade internacional, principalmente em um momento em que o Brasil vinha importando bastante, também é importante do ponto de vista do orçamento porque tudo que o Brasil exporta, de uma certa maneira, se não na sua totalidade, mas na sua quase totalidade, é desonerado de impostos, mas em compensação, o que você importa é taxado e muitas vezes, sobretaxado. Então, o que acontece, no momento em que você importa menos, que talvez seja bom para indústria nacional, mas no ponto de vista do erário público é complicado por que está recebendo menos recursos. (MATIJASCIC, 2009, apêndice F)

Contudo, o fato de apresentar uma economia menos aberta ao comércio exterior, usualmente uma desvantagem, representa neste momento menor vulnerabilidade ao colapso externo.

Enfim, resumindo o apresentado nesta seção, o agravamento da crise financeira gerou aversão global ao risco (comumente associado aos mercados emergentes), depreciando a taxa de câmbio e restringindo o crédito. A demanda externa reduziu-se, assim como os preços das commodities, impactando diretamente nos setores exportadores (conforme análise da balança comercial). Internamente, a produção desaqueceu e acumulou estoques indesejados, além de mão-de-obra ociosa. As taxas de desemprego se elevaram, restringindo a renda e deteriorando por sua vez as expectativas dos consumidores, que passam a demandar menos, formando um ciclo de deterioração da economia, como ilustrado no ciclo da próxima página:

\footnotetext{
${ }^{14}$ Exportações e importações somadas.
} 


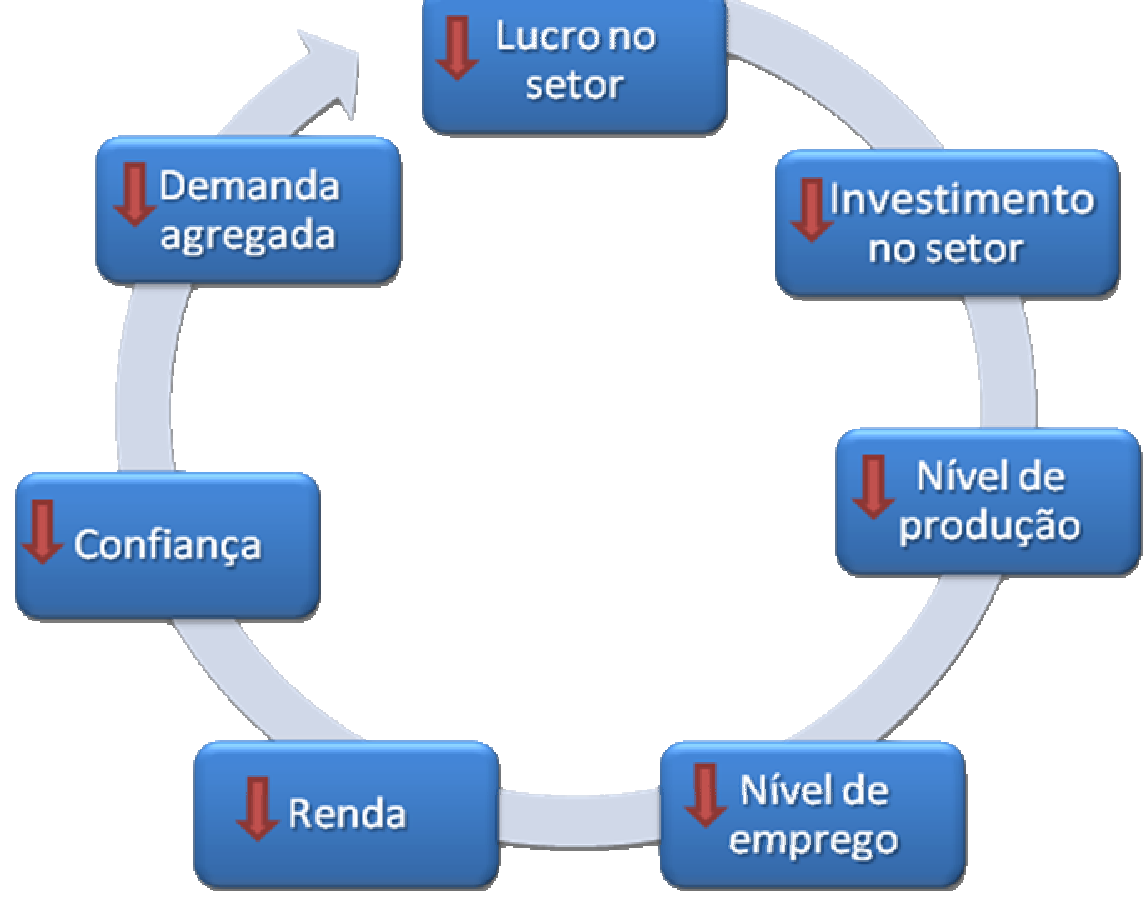

Ilustração 14: Ciclo de deterioração da economia Fonte: Elaboração da autora.

O contexto exposto tem reflexo direto no resultado do Produto Interno Bruto ${ }^{15}$ (PIB) brasileiro. Segundo os Indicadores Conjunturais de 2009 do Instituto Brasileiro de Geografia e Estatística (IBGE), o PIB registrou um crescimento de 5,1\%, em 2008. No início de 2008, a economia demonstrava dinamismo maior do que o previsto, entretanto, a partir do mês de outubro o comportamento das variáveis da economia sofreram forte reversão, resultando numa desaceleração acentuada de $3,6 \%$ no PIB do último trimestre de 2008 , de acordo com a Tabela 5 , na página seguinte:

\footnotetext{
15 "Refere-se ao valor do conjunto de todos os bens e serviços produzidos dentro do território econômico de um país em um determinado período." (BACEN, 2009, glossário)
} 
Tabela 5: Crescimento do PIB

\begin{tabular}{|c|c|c|c|c|c|c|}
\hline Taxas (\%) & $\begin{array}{c}4^{0} \text { Trim } \\
2007\end{array}$ & $\begin{array}{c}1^{0} \text { Trim } \\
2008\end{array}$ & $\begin{array}{c}2^{\circ} \text { Trim } \\
2008\end{array}$ & $\begin{array}{c}3^{\circ} \text { Trim } \\
2008\end{array}$ & $\begin{array}{c}4^{\circ} \text { Trim } \\
2008\end{array}$ & \\
\hline $\begin{array}{l}\text { Acumulado ao longo } \\
\text { do ano / mesmo } \\
\text { periodo do ano } \\
\text { anterior - Tabela } 3\end{array}$ & 5,7 & 6,1 & 6,2 & 6,4 & 5,1 & \\
\hline $\begin{array}{l}\text { Últimos quatro } \\
\text { trimestres / quatro } \\
\text { trimestres } \\
\text { imediatamente } \\
\text { anteriores - Tabela } 4\end{array}$ & 5,7 & 5,9 & 6,0 & 6,3 & 5,1 & $\begin{array}{l}\text { Crescimento } \\
\text { acima da média } \\
\text { dos últimos } \\
\text { anos }\end{array}$ \\
\hline $\begin{array}{l}\text { Trimestre / mesmo } \\
\text { trimestre do ano } \\
\text { anterior - Tabela } 2\end{array}$ & 6,1 & 6,1 & 6,2 & 6,8 & & $\begin{array}{l}\text { Crescimento } \\
\text { acima do } \\
4^{\circ} \text { Trim } 2007\end{array}$ \\
\hline $\begin{array}{l}\text { Trimestre / trimestre } \\
\text { imediatamente } \\
\text { anterior (com ajuste } \\
\text { sazonal) - Tabela } 7\end{array}$ & 1,8 & 1,6 & 1,6 & 1,7 & & $\begin{array}{l}\text { Impacto da } \\
\text { crise }\end{array}$ \\
\hline
\end{tabular}

Fonte: IBGE, Diretoria de Pesquisas, Coordenação de Contas Nacionais. Elaboração: Teixeira (2009).

A llustração 15, a seguir, demonstra as consecutivas quedas na percentagem de crescimento do PIB depois que a crise financeiro-econômica se instalou no país:

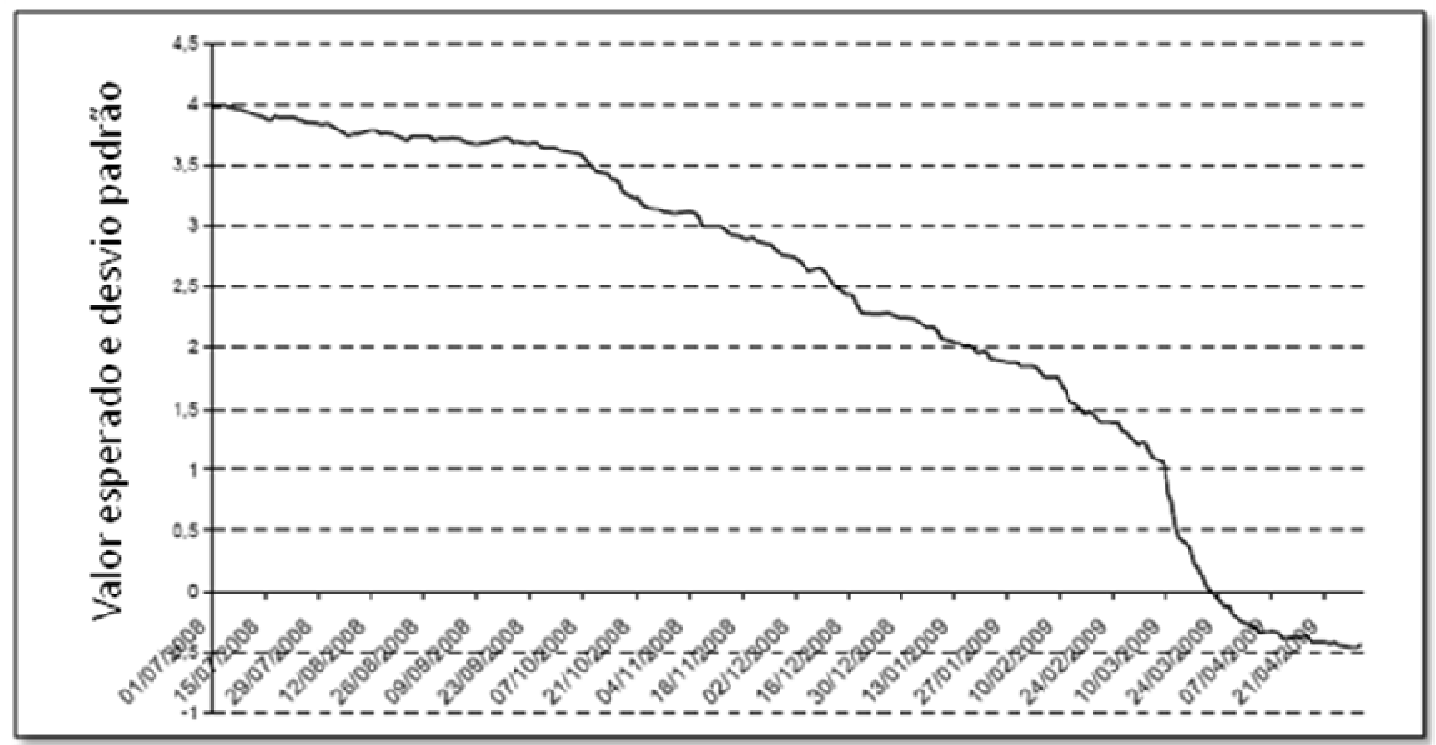

Ilustração 15: Evolução das expectativas de crescimento do PIB para 2009 Fonte: Boletim Informativo do Senado n.4 (2009)

Em relação às atuais expectativas de crescimento, o relatório Focus do Banco Central de 12 de junho de 2009 indica decréscimo de 0,55\% para o PIB em 2009. Entretanto, continuam a projetar uma reação para 2010 de 3,5\% de crescimento do PIB. Quanto ao tema, o Boletim Informativo do Senado Federal (2009) acredita que está havendo uma acomodação, após a forte deterioração ocorrida na primeira quinzena de março, quando o IBGE divulgou resultados piores que os esperados 
referentes ao PIB do quarto trimestre de 2008. Nesse sentido, o entrevistado Paulo Henrique Feijó explana:

\begin{abstract}
Acho que podemos dizer que no momento em que a crise pegou o país, ele estava justamente num programa de gastos do governo com incentivo de crescimento. Encontrou o carro a uma determinada velocidade, o país dentro da velocidade, deu o primeiro freio de arrumação nesse grande carro e agora ele está tentando retomar a sua velocidade a partir de alguns incentivos pelo próprio governo. O orçamento acaba sofrendo reflexos por se tratar de receitas e despesas. (FEIJÓ, 2009, apêndice E)
\end{abstract}

Tavares (2009) destaca que, ainda assim, o Brasil está entre os países com melhor situação na América Latina, dado o amplo espaço de manobras que possui devido às taxas de juros elevadas e a maior carga tributária de toda região, o que Ihe permite praticar maiores incentivos pelos meios tradicionais (políticas fiscais e monetárias). Na llustração 16, abaixo, é possível realizar uma análise comparativa entre as projeções do FMI de crescimento do PIB global, do PIB dos países desenvolvidos e dos países emergentes e em desenvolvimento, onde se enquadra o Brasil:

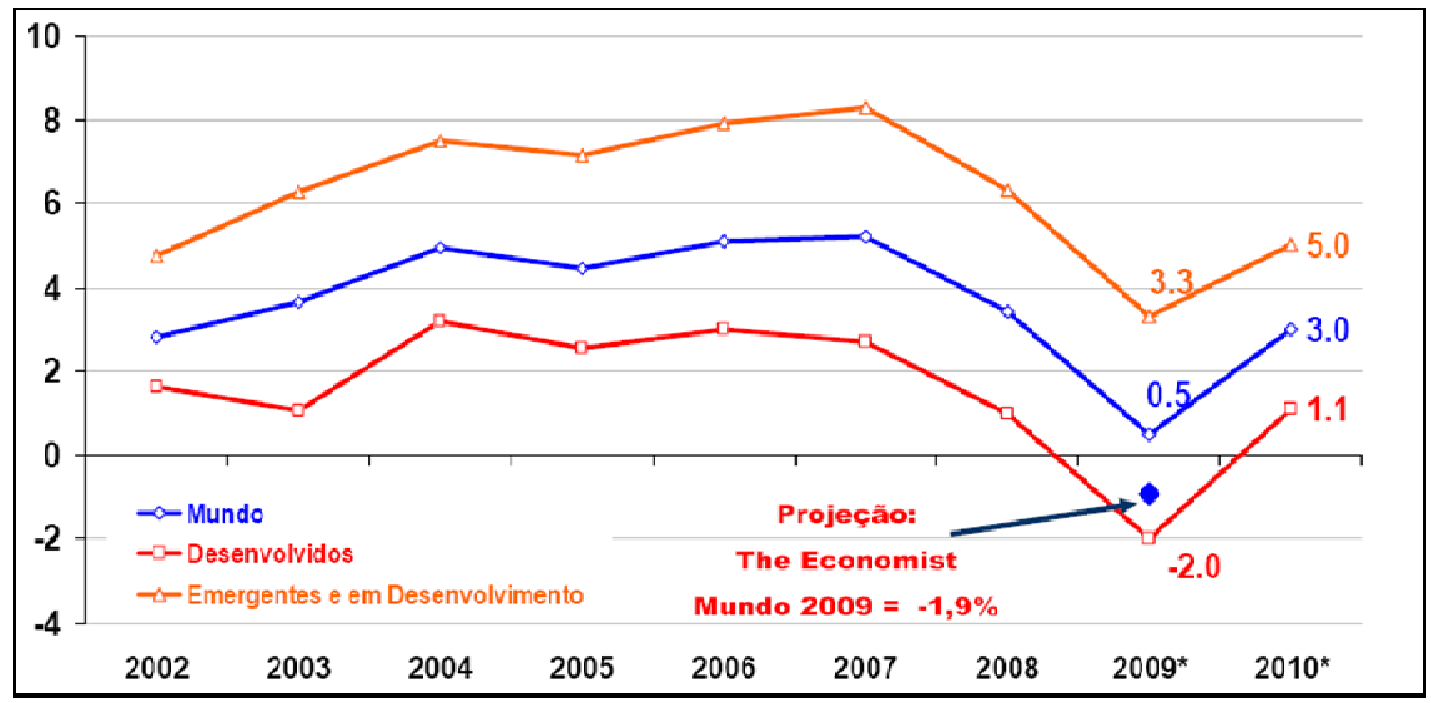

Ilustração 16: Redução acentuada do PIB mundial (em \%)

Fonte: FMI (WEO) Elaboração: MF/SPE

Lacerda (2009) acredita que o País, em geral, conta com uma boa condição macroeconômica. No entanto, "o desempenho da economia dependerá fundamentalmente das decisões e da capacidade de implementação de medidas para combater os efeitos do cenário externo adverso" (LACERDA, 2009, p.10). Caso contrário, as previsões otimistas para 2010 podem não se concretizar. 
Neste contexto, cabe ao governo exercer sua função estabilizadora, definida por Musgrave e Musgrave (1980) como:

O uso da política orçamentária visando a manutenção de um elevado nível de emprego, um razoável grau de estabilidade no nível de preços, uma taxa apropriada de crescimento econômico, e ainda o alcance da estabilidade na balança de pagamentos. (MUSGRAVE; MUSGRAVE, 1980, p.6)

A teoria geral keynesiana conduziu o pensamento econômico a uma política fiscal de despesas intensivas como terapêutica das crises. A partir dessas reflexões, parte-se para a análise geral dos efeitos reativos e proativos causados pela crise financeira e econômica global nas finanças públicas brasileiras, em especial, no orçamento público federal brasileiro.

\subsection{O Impacto da Crise nas Finanças Públicas e no Orçamento Público Federal}

No decorrer deste trabalho buscou-se construir os alicerces teóricos e contextuais para possibilitar a apreciação de documentos diversos que informam os múltiplos efeitos do atual colapso financeiro e econômico nas finanças públicas do Brasil, principalmente, nos grandes números do orçamento público da União.

Os parâmetros que balizaram a formulação do Projeto de Lei Orçamentária Anual (PLOA) para 2009 (PL $\mathrm{n}^{\circ} 38$ de 2008) estavam inseridos num cenário econômico otimista que foi se mostrando precipitado à medida que a desaceleração da economia mundial começou a afetar efetivamente a atividade econômica doméstica brasileira. Esta situação impôs ao governo e seus técnicos o desafio de realizar procedimentos inovadores de tomada de decisão referente a reestimativas de receitas e despesas diante de circunstâncias econômicas imprevisíveis, afim de fomentar a economia doméstica e estimular a demanda agregada, possibilitando a retomada do crescimento e a elevação no nível de emprego e renda.

Em 27 de agosto de 2008, o Presidente da República encaminhou ao Congresso Nacional o Projeto de Lei Orçamentária para o ano de 2009 (PLOA 2009), sendo revisado pelo próprio Poder Executivo em 21 de novembro de 2008. 
Conforme o Informativo Conjunto CONORF - COFF $^{16}$ № 01/2008, o valor inicial total da proposta orçamentária para 2009 era de $R \$ 1.664,7$ bilhões, dos quais $\mathrm{R} \$ 525,5$ bilhões referiam-se ao refinanciamento (rolagem) da dívida pública, de cunho meramente contábil. Desconsiderando-se este valor, o Orçamento Geral da União Efetivo atingia a $\mathrm{R} \$ 1.139,2$ bilhões, dos quais $\mathrm{R} \$ 79,7$ bilhões correspondem ao orçamento de investimento das empresas estatais federais e $R \$ 1.059,5$ bilhões aos orçamentos fiscal (efetivo) e da seguridade social, como pode ser visualizado na Tabela 6:

Tabela 6: Síntese da Proposta Orçamentária para 2009 (R\$ bilhões).

\begin{tabular}{|c|c|c|c|c|}
\hline \multirow{2}{*}{ Descrição } & \multicolumn{4}{|c|}{2009} \\
\hline & \multicolumn{2}{|c|}{ Receitas } & \multicolumn{2}{|c|}{ Despesas } \\
\hline 1. Orçamento Geral da União & $\mathrm{R} \$$ & $1.664,70$ & & $1.664,70$ \\
\hline 2. Refinanciamento da Dívida Pública & $\mathrm{R} \$$ & 525,50 & $\mathrm{R} \$$ & 525,50 \\
\hline 3. Orçamento Geral da União Efetivo (1 - 2) & $\mathrm{R} \$$ & $1.139,20$ & $\mathrm{R} \$$ & $1.139,20$ \\
\hline 4. Orçamento de Investimento das Estatais & $\mathrm{R} \$$ & 79,70 & $\mathrm{R} \$$ & 79,70 \\
\hline 5. Orçamentos Fiscal Efetivo e da Seg. Social (3 - 4) & $\mathrm{R} \$$ & $1.059,00$ & $\mathrm{R} \$$ & $1.059,00$ \\
\hline 5.1 Orçamento Fiscal Efetivo & $\mathrm{R} \$$ & 671,80 & $\mathrm{R} \$$ & 633,80 \\
\hline 5.2 Orçamento da Seguridade Social & $\mathrm{R} \$$ & 387,70 & $\mathrm{R} \$$ & 425,70 \\
\hline
\end{tabular}

Fonte: PLOA 2009 . Elaboração: CONORF- COFF (2008)

O projeto inicial também previa 4,5\% de crescimento para o PIB (inferior aos $5 \%$ previstos na LDO 2009) representando um valor nominal do PIB de $R \$ 3.186,6$ bilhões, além de queda na inflação IPCA, dívida líquida de 39,3\% do PIB e resultado primário de $3,80 \%$ do PIB, sendo 2,85\% para o governo central (Orçamentos Fiscal e Seguridade Social), correspondendo a $R \$ 90,8$ bilhões e 0,95\% dos Estados e Municípios, equivalendo a $\mathrm{R} \$ 30,3$ bilhões.

A proposta foi submetida a modificações pelo Congresso por meio da Comissão Mista de Planos, Orçamentos Públicos e Fiscalização (CMO) e, posteriormente sancionada pelo Presidente da República transformando-se na Lei no 11.897 de 30 de dezembro de 2008.

Conforme previsto no artigo $71, \S 4^{\circ}$ da Lei de Diretrizes Orçamentárias (LDO) para 2009 (Lei $n^{\circ} 11.768$ de 14 de agosto de 2008), fundamentado no artigo $52 \mathrm{da}$, Lei de Responsabilidade Fiscal $(\mathrm{LRF})^{17}$, o Poder Executivo encaminhará ao

\footnotetext{
${ }^{16}$ A Consultoria de Orçamento e Fiscalização Financeira (COFF) é um órgão institucional da Câmara dos Deputados, integrante da estrutura da Diretoria Legislativa, de natureza consultiva e de assessoramento. A Consultoria de Orçamentos, Fiscalização e Controle (CONORF) é órgão técnico incumbido de prestar assessoramento ao Senado Federal e ao Congresso Nacional nas áreas de planos, orçamentos públicos, fiscalização e controle.

${ }^{17}$ Lei Complementar $n^{\circ} 101$ de 04 de maio de 2000
} 
Congresso Nacional e aos órgãos referidos no art. 20 da LRF, relatório bimestral apreciado pela $\mathrm{CMO}$ com a avaliação das receitas, das despesas não-financeiras e dos parâmetros e projeções de variáveis. Baseado nestes documentos, o Poder Executivo procedeu alterações na programação orçamentária e financeira por

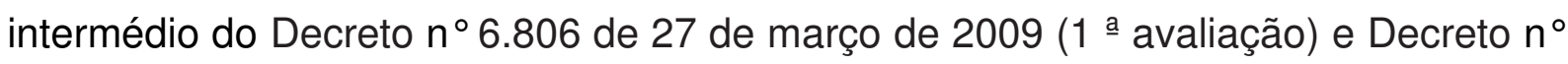
6.867 de 29 de maio de 2009 (2 $2^{\mathrm{a}}$ avaliação). Estes documentos transparecem as mais recentes alterações no orçamento e nas finanças públicas, passando a ser o foco de análise da presente pesquisa.

\subsubsection{Receitas e Despesas do Governo Central}

Em 2008, conforme dados do IPEA (2009) a receita do governo federal cresceu $7,7 \%$ em termos reais ${ }^{18}$, com relação ao ano de 2007 . Entre os meses de janeiro e outubro de 2008, ocorreu expressiva expansão de $6,4 \%$ no PIB reflexo do crescimento acelerado da economia. No entanto, o último trimestre de 2008 respondeu à crise econômica recém-chegada com retração de $3,6 \%$ do PIB, decorrente da redução expressiva de $22,7 \%$ na arrecadação dos tributos ${ }^{19}$, que havia crescido 10,3\% entre janeiro e outubro de 2008 com relação ao mesmo período de 2007. Dados isolados do ano de 2009 mostram queda da arrecadação de $9,11 \%$ no primeiro bimestre de 2009 com relação ao mesmo bimestre de 2008 . A llustração 17, na próxima página, demonstra a variação real das receitas federais em relação ao mesmo mês do ano anterior:

\footnotetext{
${ }^{18}$ Utilizando-se o Índice Nacional de Preços ao Consumidor Amplo (IPCA) como deflator.

${ }^{19}$ Soma do IRPJ, do CSLL e do IRPF em termos reais sobre ganhos de capital.
} 


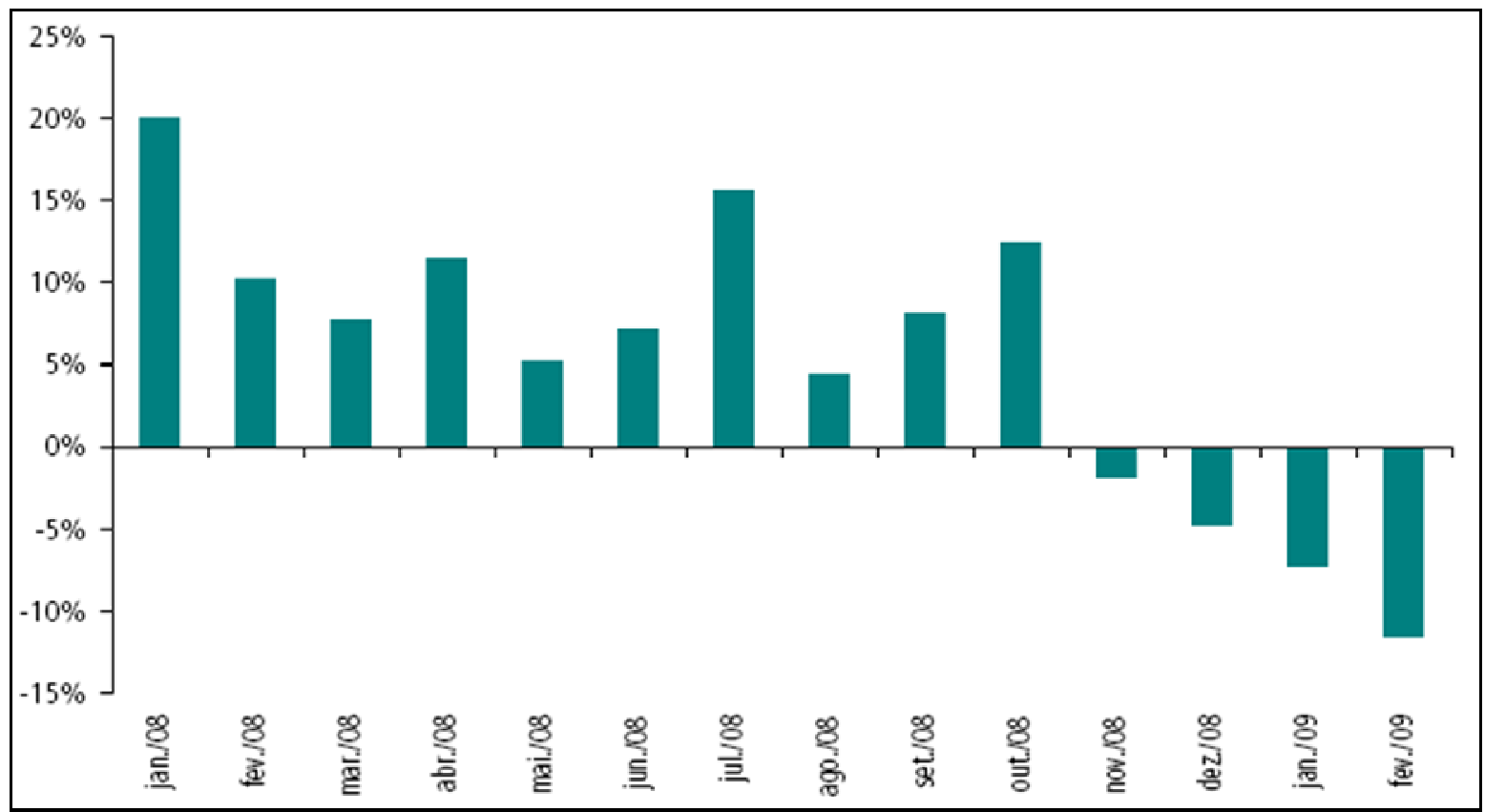

Ilustração 17: Variação Real das Receitas Federais (em relação ao mesmo mês do ano anterior) Fonte: BCB. Elaboração: IPEA (2009a)

\section{Adentrando este tópico, Cristiano Portugal enfatiza que:}

A questão chave é essa. A arrecadação está caindo com a desaceleração, mas o governo tem que fazer alguma coisa, no sentido de fazer uma política anticíclica para a retomada de crescimento. Então, ele ampliou as medidas que já estavam sendo tomadas, como a desoneração tributária, aumentou os gastos na parte de investimento e infra-estrutura, classe social e a política habitacional. (PORTUGAL, 2009, apêndice C)

Neste contexto, Maria Liz Roarelli, esclarece:

Do ponto de vista do orçamento público federal brasileiro, teve a conseqüência imediata da queda das receitas, a queda da arrecadação. Isso não afetou o orçamento de 2008 porque já vinha com uma bolha de arrecadação muito alta, que acabou o ano cumprindo sua meta de superávit e ainda sobrando dinheiro. Em 2009 é que foi mais afetado pela crise porque começou o ano com a receita já em queda. No primeiro trimestre reduziu $R \$ 3$ bilhões da receita primária total e havia uma queda na receita em termos reais também. Então, teve um impacto imediato sobre arrecadação por causa da queda do PIB, além disso, o governo com as medidas de desonerações, as medidas provisórias. Estimou só para o ano de 2009 uma queda na arrecadação de $R \$ 20$ bilhões. Na verdade é uma estimativa de desoneração, não é uma estimativa de queda da arrecadação, porque se você não estivesse desonerado, é possível que sua arrecadação caísse mais. Então, essa desoneração é justamente pra manter níveis compatíveis de crescimento econômico pra ter uma arrecadação razoável, não tão em queda assim. (ROARELLI, 2009, apêndice D)

Face ao adensamento das dificuldades na conjuntura o orçamento público foi submetido a adaptações, conforme mencionado anteriormente. A Tabela 7, a seguir, informa a evolução das modificações dos montantes da receita: 
Tabela 7: Receitas $2008-2009$

\begin{tabular}{|c|c|c|c|c|c|c|c|c|c|c|c|}
\hline \multirow{3}{*}{ Discriminação } & \multirow{3}{*}{$\begin{array}{c}2008 \\
\text { Real } \\
\% \mathrm{PIB}\end{array}$} & \multicolumn{6}{|c|}{2009} & \multicolumn{4}{|c|}{$\begin{array}{l}\text { Variações da } 2^{3} \text { Avaliação em Relação } \\
\text { a }\end{array}$} \\
\hline & & \multicolumn{2}{|l|}{ Lei } & \multicolumn{2}{|c|}{$\begin{array}{c}1^{2} \text { Avaliação } \\
\text { (Decreto 6.808/09) }\end{array}$} & \multicolumn{2}{|c|}{$\begin{array}{c}2^{2} \text { Avaliação } \\
\text { (Decreto } 6.867 / 09 \text { ) }\end{array}$} & $\begin{array}{l}\text { Leì } \\
2009\end{array}$ & $1^{3}$ Aval & $\begin{array}{c}1^{\text {s }} \\
\text { Aval }\end{array}$ & $\begin{array}{l}2008 \\
\text { Real }\end{array}$ \\
\hline & & RS milhões & $\% \mathrm{PIB}$ & R\$ milhöes & $\% \mathrm{PIB}$ & R\$ milhões & $\% \mathrm{PIB}$ & \multicolumn{2}{|c|}{ RS milhões } & \multicolumn{2}{|c|}{$\%$ PIB } \\
\hline RECEITA TOTAL & 24,83 & $805.286,1$ & 25,52 & $756.946,7$ & 24,48 & $745.206,7$ & 24,39 & $(60.079,4)$ & $(11.740,1)$ & $(0,09)$ & $(0,44)$ \\
\hline Receita Administrada RFB ${ }^{(1)}$ & 16,14 & $522.351,6$ & 16,55 & $484.974,1$ & 15,68 & $473.034,0$ & 15,48 & $(49.317,6)$ & $(11.940,1)$ & $(0,21)$ & $(0,66)$ \\
\hline Arrecadação Liquida INSS & 5,65 & $187.831,8$ & 5,95 & $180.936,3$ & 5,85 & $180.936,3$ & 5,92 & $(6.895,5)$ & 0,0 & 0,07 & 0,27 \\
\hline Receitas Năo Administradas & 3,04 & $92.602,7$ & 2,93 & $88.536,4$ & 2,86 & $88.736,4$ & 2,90 & $(3.866,3)$ & 200,0 & 0,04 & $(0,13)$ \\
\hline Operações com Ativos & 0,00 & $2.500,0$ & 0,08 & $2.500,0$ & 0,08 & $2.500,0$ & 0,08 & 0,00 & 0,00 & 0,00 & 0,08 \\
\hline TRANSFERÊNCIAS (-) & 4,41 & $143.184,4$ & 4,54 & $127.255,5$ & 4,12 & $124.850,9$ & 4,09 & $(18.333,5)$ & $(2.404,6)$ & $(0,03)$ & $(0,32)$ \\
\hline RECEITA LIQQUIDA & 20,42 & $662.101,6$ & 20,98 & $629.691,2$ & 20,37 & $620.355,7$ & 20,30 & $(41.745,9)$ & $(9.335,5)$ & $(0,06)$ & $(0,12)$ \\
\hline
\end{tabular}

(1) Exceto INSS.

Fonte: SOF, RFB (Receita Federal do Brasil), Decretos citados, IBGE. Elaboração: COFF (2009)

Como podem ser observados na Tabela 7 , os reajustes na previsão das receitas foram majoritariamente negativos. Nota-se o corte total de $R \$ 41.745,9$ milhões na comparação do valor da receita líquida da LOA 2009 para a $2^{a}$ avaliação da mesma. Para a COFF (2009):

A queda nas estimativas é, em termos reais, modesta. A previsão de receitas líquidas de 2009, comparadas com 2008, exercício recorde em arrecadação, tanto administrada, como não administrada, mostra queda de apenas $0,12 \%$ do Produto, equivalente a $R \$ 3,7$ bilhões, usando-se a projeção oficial do PIB da $2^{\mathrm{a}}$ avaliação. (COFF, 2009, p.17)

As previsões de contração na receita estão diretamente ligadas às expectativas de queda generalizada na arrecadação do governo, como demonstra a Tabela 8:

Tabela 8: Receita Líquida Administrada pela RFB, 2008 - 2009 - Previsão e Arrecadação Jan-Abr ( $\mathrm{R} \$$ milhões)

\begin{tabular}{|c|c|c|c|c|c|c|}
\hline \multirow{2}{*}{ RECEITAS } & \multirow{2}{*}{\begin{tabular}{|c|c}
$1^{\circ}$ \\
$\begin{array}{c}\text { Quadrimestre } \\
\text { de } 2008\end{array}$ \\
Arrecadado
\end{tabular}} & \multicolumn{3}{|c|}{$1^{\circ}$ Quadrimestre de 2009} & \multirow{2}{*}{\begin{tabular}{|c}
$1^{\circ}$ \\
$\begin{array}{c}\text { Quadrimestre } \\
\text { de } 2008\end{array}$ \\
$\%$ do PIB
\end{tabular}} & \multirow{2}{*}{$\begin{array}{c}1^{\circ} \\
\begin{array}{c}\text { Quadrimestre } \\
\text { de } 2009\end{array} \\
\% \text { do PIB }\end{array}$} \\
\hline & & Previsto (1) & Arrecadado & Frustraçäo & & \\
\hline IMPOSTO SOBRE A IMPORTAÇÃO & 4.815 & 6.781 & 5.464 & $(1.318)$ & 0,54 & 0,58 \\
\hline IMPOSTO SOBRE A EXPORTAÇÃO & 12 & 20 & 31 & 11 & 0,00 & 0,00 \\
\hline IMPOSTO SOBRE PRODUTOS INDUSTRIALIZADOS & 11.604 & 10.567 & 8.509 & $(2.058)$ & 1,30 & 0,91 \\
\hline I.P.I. - FUMO & 1.048 & 1.027 & 1.076 & 50 & 0,12 & 0,11 \\
\hline I.P.I. - BEBIDAS & 859 & 863 & 776 & (88) & 0,10 & 0,08 \\
\hline I.P.I. - AUTOMÓVEIS & 1.974 & 330 & 343 & 13 & 0,22 & 0,04 \\
\hline I.P.I. - VINCULADO Ȧ IMPORTAÇÃO & 2.820 & 3.806 & 2.858 & $(948)$ & 0,31 & 0,31 \\
\hline I.P.I. - OUTROS & 4.903 & 4.541 & 3.456 & $(1.085)$ & 0,55 & 0,37 \\
\hline IMPOSTO SOBRE A RENDA & 65.279 & 67.208 & 65.494 & (1.714) & 7,29 & 7,00 \\
\hline I.R. - PESSOA FISICA & 5.398 & 5.358 & 5.038 & $(320)$ & 0,60 & 0,54 \\
\hline I.R. - PESSOA JURIDICA & 32.081 & 30.931 & 30.190 & (741) & 3,58 & 3,22 \\
\hline I.R. - RETIDO NA FONTE & 27.800 & 30.919 & 30.267 & (653) & 3,10 & 3,23 \\
\hline
\end{tabular}




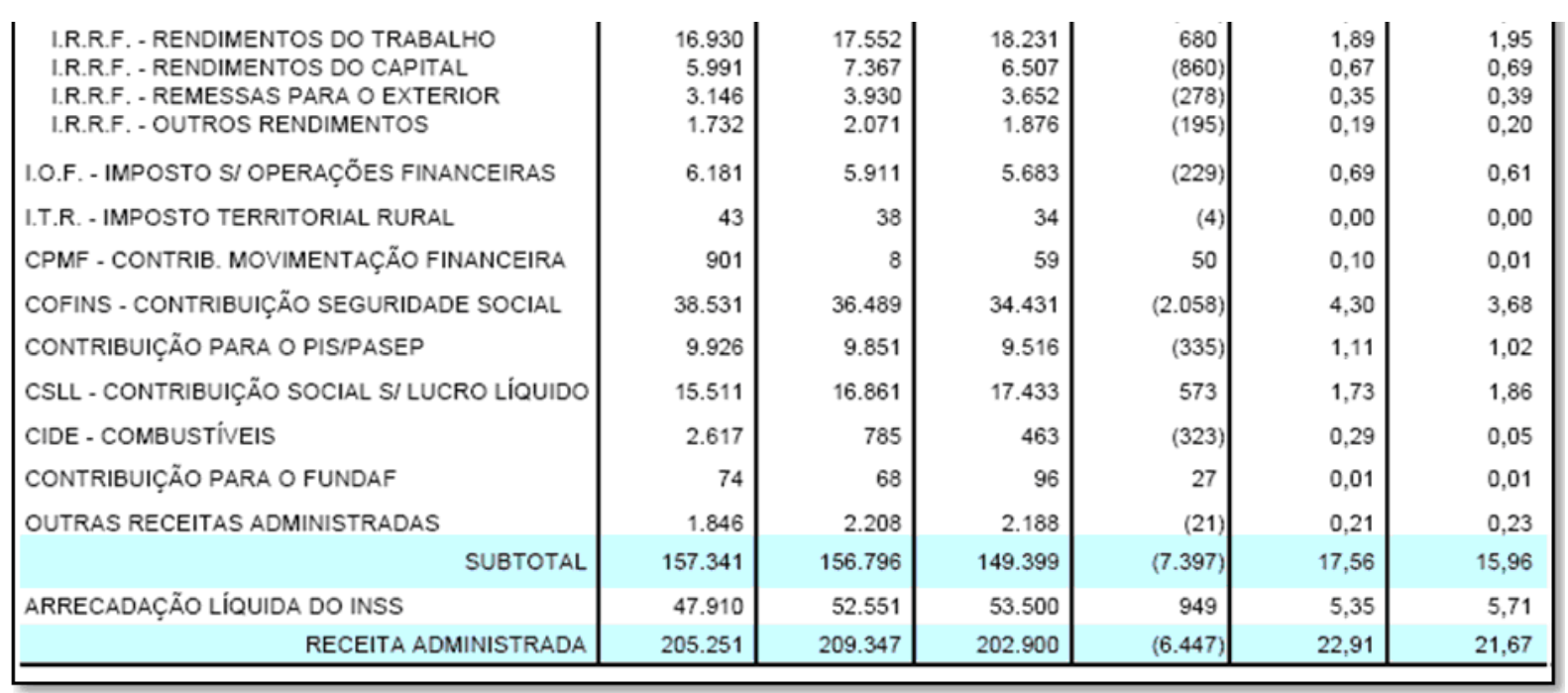

(1)Refere-se à previsão do Poder Executivo no Decreto 6.808/09.

Fonte: RFB, INSS, SOF. Elaboração: COFF (2009)

A Tabela 8, acima apresentada, inova a análise por contribuir com dados reais de arrecadação em 2009, possibilitando a comparação entre o previsto e o efetivamente arrecadado. Nesta comparação apura-se frustração de quase $R \$ 7,4$ ${ }^{20}$ bilhões para as receitas administradas pela Receita Federal do Brasil (RFB), liderada pela Cofins (- $R \$ 2,1$ bilhões), imposto de importação (- $R \$ 1,3$ bilhão); IPIoutros (- $R \$ 1,1$ bilhão); IPI vinculado à importação (- $R \$ 1$ bilhão) e imposto de renda na fonte sobre rendimentos de capital (quase $-\mathrm{R} \$ 900$ milhões) e compensada em parte pelas receitas previdenciárias ( $\mathrm{R} \$ 950$ milhões acima do programado) e, principalmente, pelas não administradas ( $\mathrm{R} \$ 3$ bilhões, incluindo a contribuição ao FGTS). As transferências a estados e municípios foram inferiores (menos $R \$ 760$ milhões) ao previsto.

$\mathrm{Na}$ outra ponta, o governo tem que socorrer os estados e municípios pela diminuição de sua arrecadação e isso ensejou alguns bilhões a serem repassados da União para os estados e municípios. Então, o governo federal acaba tendo um papel de tentar equalizar os vários lados, tanto o lado do cidadão, quanto o lado dos entes federativos. (FEIJÓ, 2009, apêndice E)

A popular redução de alíquotas do IPI sobre veículos, que já havia sido prevista para 2009 , significou diminuição de $83,7 \%$ na arrecadação em relação a 2008. Acerca das desonerações tributárias, a COFF avalia que:

Neste primeiro quadrimestre a RFB estima que perdeu por conta de desonerações, em relação ao mesmo quadrimestre de $2008, \mathrm{R} \$ 8,4$ bilhões a preços de 2009 , levando à conclusão que grosso modo toda a perda de

${ }^{20}$ Exceto a arrecadação do INSS. 
receita se deveria a medidas tributárias de estímulo à atividade econômica. As receitas do INSS aumentam em relação a 2008 o equivalente a $0,3 \%$ do PIB, e aumentam também em relação à $1^{\underline{a}}$ avaliação.(COFF, 2009, p.17)

O Anexo 1, situado nas seções finais deste trabalho, apresenta uma tabela disponibilizada pela Consultora do CONORF, Maria Liz Roarelli, com o detalhamento de todas as medidas de desoneração tributária adotadas até abril deste ano, bem como o montante que deixará de ser arrecadado em 2009, um total de $R \$ 20,3$ bilhões.

$\mathrm{Na}$ apreciação da Consultoria de Orçamento e Fiscalização Financeira (COFF), o desempenho da arrecadação de janeiro a abril de 2009 foi decepcionante, ficando as receitas líquidas abaixo da reprogramação oficial em cerca de $R \$ 2,7$ bilhões.

Do ponto de vista das despesas, ocorre o inverso das receitas. As despesas primárias (despesas não-financeiras) têm apresentado aumentos progressivos tanto em relação ao mesmo mês em 2008, quanto em relação ao mês anterior.

Dados do Senado Federal (2009) indicam que no primeiro trimestre de 2009, as despesas primárias foram de $R \$ 128,2$ bilhões, aumentando $R \$ 20,5$ bilhões em relação ao mesmo trimestre do ano anterior. O boletim do Senado Federal (2009) atribui este resultado, em grande parte, ao aumento da despesa com pessoal (reestruturação de carreiras e do pagamento de sentenças), quase $R \$ 8$ bilhões de aumento no primeiro trimestre de 2009, comparado com o mesmo período do ano anterior. Outro fator é aumento do custeio, em $R \$ 5,8$ bilhões, especialmente das despesas do Ministério da Saúde.

A seguir, a llustração 18 representa a destinação geral de recursos do Orçamento da União por natureza da despesa: 


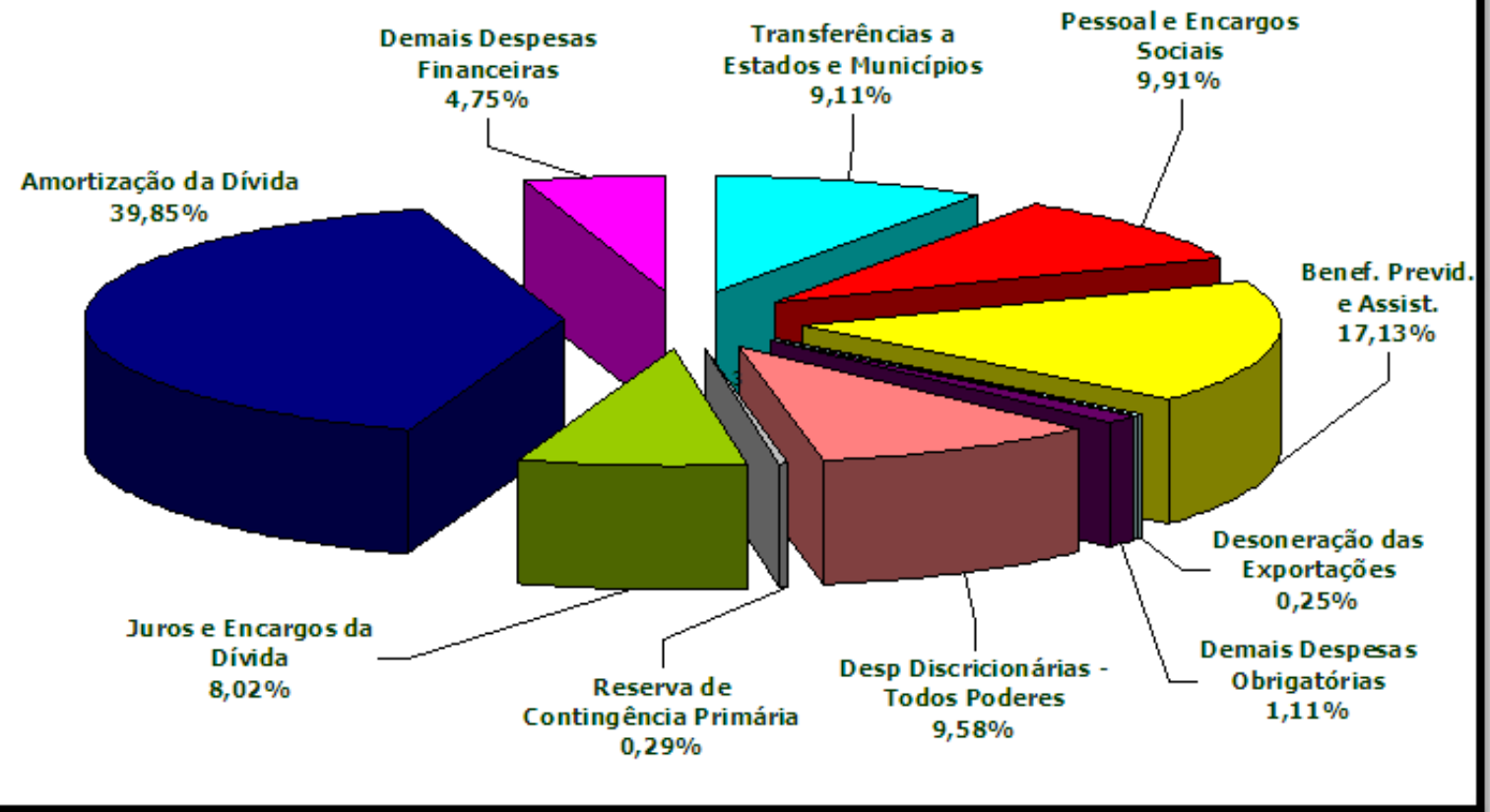

llustração 18: Visão Geral Orçamento 2009.

Fonte:Apresentação SOF $^{21}$.

Passando à verificação dos valores das despesas e tendo como base a $2^{\text {a }}$ Avaliação da LOA (Decreto 6.752/09), observa-se que findo o primeiro quadrimestre, pouco menos de $30 \%$ das despesas foram realizadas, conforme Tabela 9, seguinte:

Tabela 9: Despesas Primárias e resultados da União.

\begin{tabular}{|c|c|c|c|c|c|c|c|c|c|}
\hline $\begin{array}{l}\text { ORÇAMENTO, } 2009 \\
\text { Despesas Primárias e Resultado da Uniäo }\end{array}$ & & & & & & & & & \\
\hline \multirow{3}{*}{ Discriminaçäo } & \multicolumn{4}{|c|}{ Previsão 2009} & \multicolumn{2}{|c|}{$1^{\circ}$ Quadrimestre } & \multicolumn{2}{|c|}{$\begin{array}{c}2^{\mathrm{a}} \text { Avaliaçäo } \\
\text { (Decreto } 6.867 / 09 \text { ) }\end{array}$} & \multirow{3}{*}{$\begin{array}{c}\begin{array}{c}\text { Diferença } \\
2^{2} \text { Avaliação } \\
\text { - Lei }\end{array} \\
\text { RS milhões }\end{array}$} \\
\hline & \multicolumn{2}{|l|}{ Lei } & \multicolumn{2}{|c|}{$\begin{array}{l}1^{2} \text { Avaliaçãa } \\
\text { (Decreto } 6.808)\end{array}$} & \multirow{2}{*}{$\begin{array}{c}\text { Realizado } \\
\text { RS milhões }\end{array}$} & \multirow{2}{*}{ 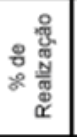 } & \multirow{2}{*}{ RS milhões } & \multirow{2}{*}{$\begin{array}{c}\% \\
\text { PIB }\end{array}$} & \\
\hline & RS milhões & $\begin{array}{c}\% \\
\text { PIB }\end{array}$ & RS milhões & $\begin{array}{c}\% \\
\text { PIB }\end{array}$ & & & & & \\
\hline TOTAL DAS DESPESAS & $609.789,9$ & 19,32 & $578.764,8$ & 18,72 & $172.547,0$ & 29,1 & $593.124,7$ & 19,41 & $(16.665,2)$ \\
\hline Pessoal e Encargos Sociais & $154.911,9$ & 4,91 & $153.845,0$ & 4,98 & $50.463,0$ & 32,8 & $153.845,0$ & 5,03 & $(1.066,8)$ \\
\hline Beneficios da Previdência & $228.642,8$ & 7,24 & $220.992,0$ & 7,15 & $68.655,0$ & 30,8 & $223.068,1$ & 7,30 & $(5.574,7)$ \\
\hline Demais Despesas Vinculadas ao Salário Mínimo & $42.897,9$ & 1,36 & $42.897,9$ & 1,39 & $12.668,0$ & 28,5 & $44.396,3$ & 1,45 & $1.498,4$ \\
\hline Abono e Seguro Desemprego & $24.349,5$ & 0,77 & $24.349,5$ & 0,79 & $6.616,0$ & 26,2 & $25.277,4$ & 0,83 & 927,9 \\
\hline LOAS & $16.674,0$ & 0,53 & $16.674,0$ & 0,54 & $5.415,0$ & 31,4 & $17.226,7$ & 0,56 & 552,8 \\
\hline Renda Mensal Vitalicia - RMV & $1.874,5$ & 0,06 & $1.874,5$ & 0,06 & 637,0 & 33,7 & $1.892,2$ & 0,06 & 17,7 \\
\hline Compensação Estados Exportadores ICMS & $3.900,0$ & 0,12 & $3.900,0$ & 0,13 & 650,0 & 16,7 & $3.900,0$ & 0,13 & - \\
\hline Outras Despesas Obrigatórias & $22.045,4$ & 0,70 & $21.331,7$ & 0,69 & $4.396,0$ & 19,3 & $22.735,8$ & 0,74 & 690,4 \\
\hline Subsidios e Subvenções & $11.292,4$ & 0,36 & $6.006,9$ & 0,19 & $(426,0)$ & $(7,1)$ & $6.006,9$ & 0,20 & $(5.285,5)$ \\
\hline Sentenças Judiciais - demais & $2.098,6$ & 0,07 & $2.098,7$ & 0,07 & $1.606,0$ & 76,4 & $2.101,6$ & 0,07 & 3,0 \\
\hline Fundef/Fundeb - Complementação & $5.061,8$ & 0,16 & $5.070,2$ & 0,16 & 934,0 & 18,4 & $5.070,2$ & 0,17 & 8,3 \\
\hline Doaçōes & 107,0 & 0,00 & 107,0 & 0,00 & - & - & 110,9 & 0,00 & 3,8 \\
\hline Convênios & 265,3 & 0,01 & 265,3 & 0,01 & 89,0 & 22,8 & 390,6 & 0,01 & 125,3 \\
\hline FDA/FDNE/SUDAMSUDENE & & $\therefore$ & $1.200,0$ & 0,04 & 55,0 & 4,6 & $1.200,0$ & 0,04 & $1.200,0$ \\
\hline Fundo Constitucional do DF & 690,9 & 0,02 & 450,5 & 0,01 & 156,0 & 34,6 & 450,5 & 0,01 & $(240,4)$ \\
\hline Créditos Extraordinários & & - & $3.000,0$ & 0,10 & $1.059,0$ & 32,1 & $3.300,0$ & 0,11 & $3.300,0$ \\
\hline Fabricação de Cédulas e Moedas & & - & 600,0 & 0,02 & 207,0 & 34,5 & 600,0 & 0,02 & 600,0 \\
\hline
\end{tabular}

${ }^{21}$ Disponível em: <https://www.portalsof.planejamento.gov.br/sof/2009/ploa2009/Apresentacao_ Ministro.pdf>. Acesso em 30 de maio de 2009. 


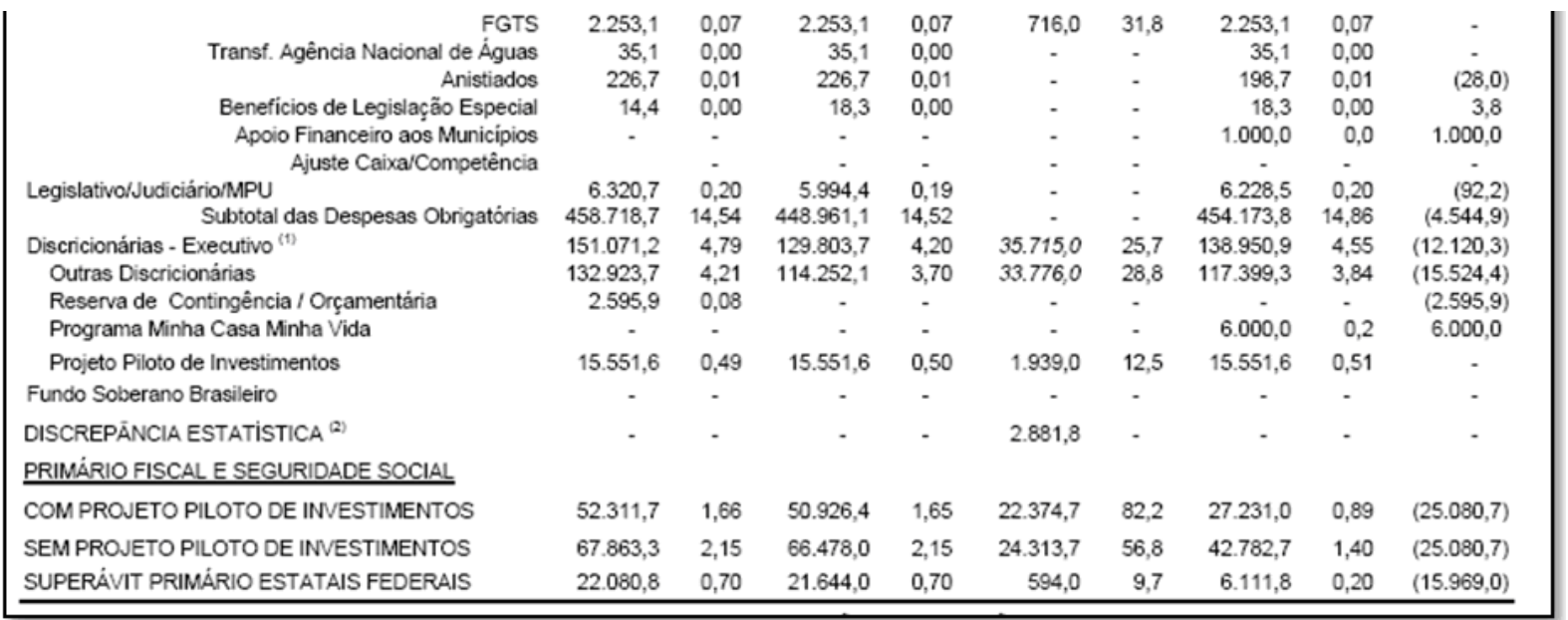

(1)Inclui no realizado despesas discricionárias dos demais poderes.

(2)Inclui no realizado ajuste metodológico referente à amortização de contratos de Itaipu com o Tesouro Nacional.

Fonte: STN, SOF e Decretos citados. Elaboração: COFF (2009).

De acordo com a Nota Técnica da COFF (2009), o item de maior execução foi o de sentenças judiciais (76\%), cujo pagamento se concentra fortemente em início de ano. As despesas com pessoal corresponderam a 33\% da previsão para todo 0 exercício, respeitando o Decreto $n^{\circ}$ 6.867. Entretanto há suspeitas que a previsão estava subestimada:

Excluídas sentenças judiciais e despesas de exercícios anteriores, a previsão para o exercício cai para $\mathrm{R} \$ 146,3$ bilhões, e o despendido, $\mathrm{R} \$$ 44,6 bilhões (pouco mais de $30 \%$ ), levando a crer que a previsão está subestimada, não apenas porque os pagamentos relativos a $13^{\circ}$ salário dos servidores ocorrem no segundo e no terceiro quadrimestres, como também porque parte dos reajustes salariais previstos para este ano começam a ter efeitos financeiros na segunda metade do ano. (COFF, 2009, p.12)

Comparando com o mesmo quadrimestre de 2008, por exemplo, cerca de $79 \%$ dos recursos já haviam sido desembolsados. Sendo assim, observa-se que as estimativas de despesas aumentam em $R \$ 14,4$ bilhões da $1^{\stackrel{a}{a}}$ para a $2^{a}$ avaliação do orçamento

Seguindo com as avaliações da COFF (2009), outro item que mereceu cautela foram os Benefícios da Previdência (quase $31 \%$ realizados) enquanto a maior parte dos dispêndios concentra-se no segundo semestre. Esta incongruência foi corrigida na segunda avaliação com o incremento de $R \$ 2,1$ bilhões.

Outros elemento que receberam acréscimos foram: as despesas vinculadas ao salário mínimo (aumentadas em $\mathrm{R} \$ 1,5$ bilhão); as despesas com a execução de créditos extraordinários ( de $R \$ 3$ bilhões para $R \$ 3,3$ bilhões, por conta da abertura 
de novo crédito ${ }^{22}$ em favor do Ministério da Integração Nacional); a inclusão de novo item de despesa obrigatória para compensar os municípios por perdas com a queda dos impostos compartilhados ( $\mathrm{R} \$ 1$ bilhão); o crédito extraordinário no valor de mais de $R \$ 1,2$ bilhão, para diversos ministérios, para o combate da influeza e auxílio a vítimas da seca e, ainda, mais $\mathrm{R} \$ 5,95$ bilhões $^{23}$ destinados a garantia contra risco de crédito para micro, pequenas e médias empresas e auxílio financeiro a estados e municípios, com o objetivo de fomentar as exportações do País.

Por fim, o COFF (2009) afirma que as despesas vêm crescendo desde 2003 e não será o contingenciamento de despesas discricionárias ou outras medidas para cortar ou adiar a execução de despesas obrigatórias que impedirão esta trajetória.

A esse respeito, Paulo Henrique Feijó opina:

Do lado da despesa você tem um forte impacto do aumento das despesas correntes, pelo menos em termos nominais pelo governo, que de um lado podemos dizer está, até certo ponto, ajudando a economia, está colocando mais dinheiro. Mas, por outro lado, cria um flanco na área fiscal a partir do momento que você quer calibrar o superávit primário para manter sua dívida sobre controle, então é lógico que a crise impacta diretamente o orçamento e isto está refletido nos diversos contingenciamentos que o governo vem fazendo ao longo do ano. (FEIJÓ, 2009, apêndice E)

\subsubsection{Resultado Primário e Endividamento do Setor Público}

Na definição de Albuquerque, Medeiros e Feijó (2008), "o Resultado Primário indica se os níveis de gastos estão compatíveis com a arrecadação, ou seja, se as receitas não-financeiras são capazes de suportar as despesas não-financeiras ${ }^{24 "}$ (ALBUQUERQUE; MEDEIROS; FEIJÓ, 2008, p.72). Destarte, o Superávit Primário ocorre quando as receitas não-financeiras superam as despesas não-financeiras possibilitando que este resultado seja utilizado para honrar compromissos, geralmente, pagamento de juros e amortizações de dívidas.

Conforme já observado, o ano de 2008 foi marcado por ótimos resultados de janeiro a setembro, inclusive resultados fiscais. Apresentou um quadro excepcional do ponto de vista da arrecadação, apesar do desempenho precário no último bimestre. "Relativamente à União, foi possível aumentar as despesas, apartar mais

\footnotetext{
${ }^{22}$ Medida Provisória n 461/09 de 15 de abril de 2009.

${ }^{23}$ Autorizados pela Medida Provisória n 464/09, de 9 de junho de 2009.

${ }^{24}$ As despesas não-financeiras = despesa total - despesas financeiras (amortização, juros, encargos da dívida, aquisição de título de capital já integralizado, concessão de empréstimos com retorno garantido e transferência entre entidades federais), segundo Albuquerque, Medeiros e Feijó (2008).
} 
de $R \$ 14$ bilhões para a formação do Fundo Soberano do Brasil (FSB) e atingir com folga a meta fiscal" (COFF, 2009, p.3). Entretanto, o quadro apresentado no último trimestre de 2008 se agravou nos primeiros meses de 2009: A redução da atividade econômica aliada às medidas de desoneração tributária vêm reduzindo a receita pública em termos reais. Essa tendência, associada ao aumento da despesa pública, tem reduzido o resultado primário, como retrata os dados do Resultado da Secretaria do Tesouro Nacional (STN) de 2009:

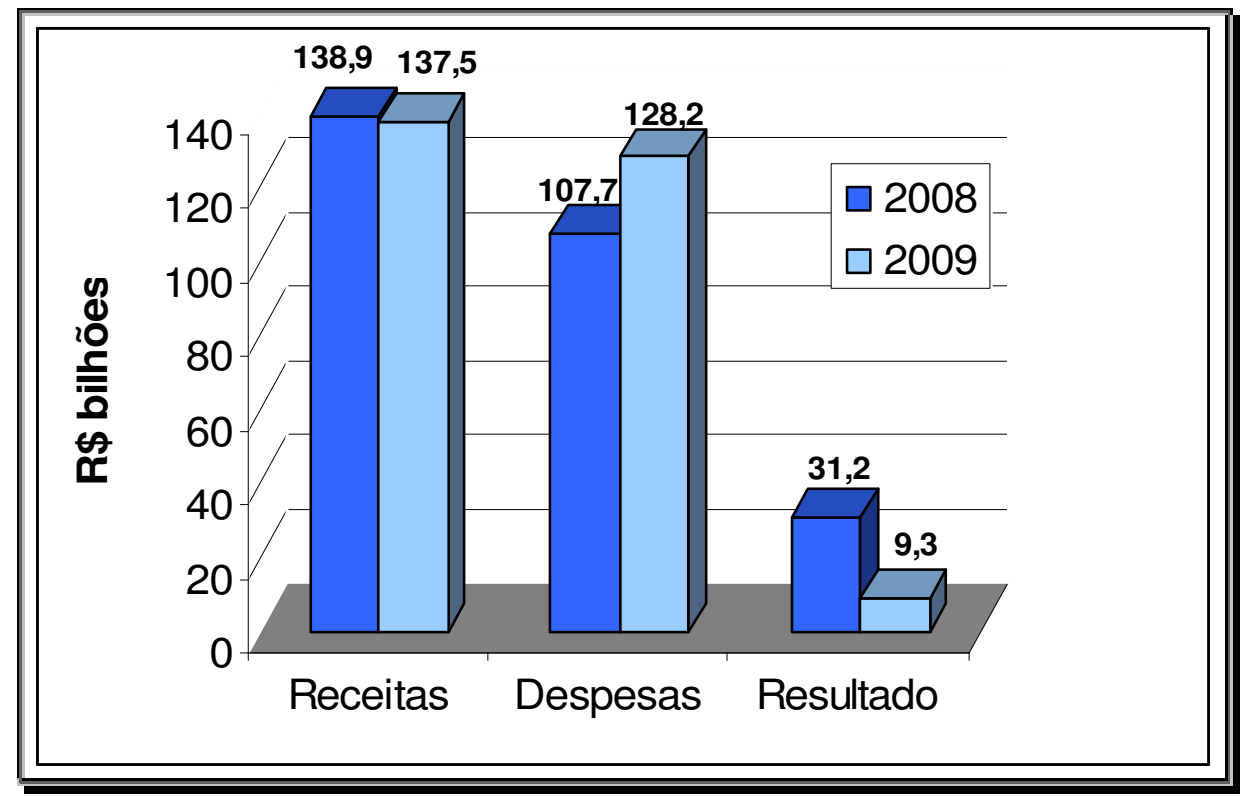

Illustração 19: Receitas, Despesas e Resultado do Governo Central.

Fonte: STN (2009)

A referida circunstância exigiu uma série de modificações nas previsões do resultado primário, como discriminado na Tabela 10:

Tabela 10: Principais Parâmetros e Projeções Econômico-Fiscais, 2007-2009.

\begin{tabular}{|c|c|c|c|c|c|c|c|c|}
\hline \multicolumn{9}{|c|}{ PRINCIPAIS PARĀMETROS E PROUEÇÓES ECONÓMICO-FISCAIS, $2007.2009^{\text {(1) }}$} \\
\hline \multirow{3}{*}{ Variavelindicador } & 2007 & 2008 & \multicolumn{6}{|c|}{2009} \\
\hline & \multirow{2}{*}{\multicolumn{2}{|c|}{ Realizado }} & LOO 2009 & Proposta & $\begin{array}{c}\text { Orçamento } \\
2009\end{array}$ & $\begin{array}{c}1^{2} \text { Avaliaçăo } \\
\text { (Dec 6.808) }\end{array}$ & $\begin{array}{l}2^{\circ} \text { Avaliaçấo } \\
\text { (Dec 6.867) }\end{array}$ & Mercado \\
\hline & & & & & & LDO 2010 & LDO 2009 & 05,0612009 \\
\hline \multicolumn{9}{|l|}{ Indicadores Fiscais em $\%$ do $\mathrm{P} \mid \mathrm{B}^{\mathrm{m}}$} \\
\hline Resultado Primário Consolidado & 3,91 & 4,00 & 3,80 & 3,80 & $3, \infty 0$ & 3,00 & 2,50 & 2,45 \\
\hline Resultado Primário Governo Central & 2,29 & 2,47 & 2,20 & 2,20 & 2,16 & 2,16 & 1,40 & ... \\
\hline Resultado Primário Estatais Federais & 0,46 & 0,49 & 0,65 & 0,65 & 0,70 & 0,70 & 0,20 & ... \\
\hline Resultado Primário Governos Regionais & 1,16 & 1,13 & 0.95 & 0.95 & 0.95 & 0.95 & 0,90 & ... \\
\hline Juros Nominais Setor Público Consolidade & $(6,14)$ & $(5,62)$ & (4.56) & (5.70) & (5.70) & - & $(4,62)$ & $(4.70)$ \\
\hline Juros Nominais Governo Central & $(4,58)$ & (3.22) & (3.13) & $(4,21)$ & $(4,21)$ & - & 3.17 & ... \\
\hline Resultado Nominal Consolidado & $(2,23)$ & $(1,53)$ & $(0,76)$ & $(1,80)$ & $(1,90)$ & - & $(2,12)$ & [2,25) \\
\hline Divida liquida (\% do P|B) & 42,03 & 36,00 & 38,00 & 39,30 & 39,30 & - & 39,40 & 39,00 \\
\hline
\end{tabular}

Fonte: COFF (2009), com adaptações. 
A meta de superávit primário em 2009 , de $3,80 \%$ em relação ao PIB, foi insistentemente mantida até que o Poder Executivo encaminhou uma proposta de alteração da meta constante na Lei de Diretrizes Orçamentárias (LDO ${ }^{25}$, via Projeto de Lei $n^{\circ}$ 15/2009, ao Congresso alterando o art. ํe o Anexo IV da LDO 2009.

Assim, com o objetivo de se adotar uma política fiscal anticíclica, por meio de aumento dos investimentos públicos, a meta fiscal do governo central foi reduzida para $2,5 \%$ do PIB, sendo de $2,15 \%$ para $1,4 \%$, das estatais de $0,70 \%$ para $0,20 \%$ e dos governos subnacionais de $0,95 \%$ para $0,90 \%$ do PIB, além da possibilidade de abatimento de outros $0,5 \%$ do PIB, equivalente a $R \$ 15,5$ bilhões, referentes ao Projeto Piloto de Investimentos (PPI) ${ }^{26}$. Existem ainda os recursos oriundos do FSB de 2008 que podem significar uma receita a mais.

A SOF (2009) avalia que, devido a esta mudança e à revisão do valor nominal do PIB, a meta para o Governo Central será reduzida em $\mathrm{R} \$ 23,7$ bilhões.

O Boletim do Senado Federal (2009) utilizou dados tanto do Banco Central do Brasil (BCB) quanto da Secretaria do Tesouro Nacional (STN) que apresentam diferenças metodológicas na apuração dos mesmos indicadores, levando a resultados distintos:

De acordo com o Banco Central, no primeiro trimestre de 2009, o setor público consolidado apresentou superávit primário de $R \$ 20,1$ bilhões, $3,01 \%$ do PIB, o que representa menos da metade do resultado alcançado no mesmo período do ano anterior, $\mathrm{R} \$ 43$ bilhões ou $6 \%$ do PIB. Esse resultado foi fortemente influenciado pela queda de $R \$ 20,3$ bilhões do resultado do Governo Central, que passou de $R \$ 31,8$ bilhões, no primeiro trimestre de 2008, para $\mathrm{R} \$ 11,5$ bilhões, no mesmo período de 2009.[...] Pela metodologia da STN, o resultado primário do Governo Central foi um superávit de $R \$ 6,5$ bilhões em março, acumulando superávit de $R \$ 9,3$ bilhões no $1^{\circ}$ trimestre de 2009 , diante do superávit apurado de $\mathrm{R} \$ 31,2$ bilhões, em igual período de 2008. (SENADO FEDERAL, 2009, p.4)

\footnotetext{
${ }^{25}$ Lei $n^{\circ} 11.897$, de 30 de dezembro de 2008.

${ }^{26}$ a partir de 2009, o grupo Petrobras será excluído do cálculo dos resultados fiscais e da dívida do setor público não financeiro.
} 
Tabela 11: Resultado Primário

\begin{tabular}{|l|r|r|r|}
\hline \multicolumn{4}{|c|}{ RESULTADO PRIMÁRIO } \\
\hline \multicolumn{3}{|c|}{ DISCRIMINAÇÃO } & \multicolumn{1}{c|}{ Jan-Mar } \\
\cline { 2 - 5 } & \multicolumn{1}{|c}{2008} & \multicolumn{1}{c|}{ RS milhöes } \\
\hline 1. RECEITA TOTAL & 170.367 & 167.095 & $(3.272)$ \\
1.1 Receita do Tesouro & 134.700 & 127.234 & $(7.467)$ \\
1.2 Receita da previdência & 35.268 & 39.411 & 4.142 \\
1.3 Receita do BACEN & 398 & 451 & 53 \\
2. TRANSF. A EST/MUN & 31.460 & 29.566 & $(1.893)$ \\
3. RECEITA LIQUIDA & 138.907 & 137.529 & $(1.378)$ \\
4. DESPESA TOTAL & 107.720 & 128.198 & 20.478 \\
4.1 Despesa do Tesouro & 62.213 & 76.171 & 13.959 \\
4.2 Beneficios da Previdencia & 45.021 & 51.466 & 6.446 \\
4.3 Despesa do BACEN & 487 & 561 & 74 \\
5. RESULTADO PRIMARIO & 31.187 & 9.331 & $(21.856)$ \\
5.1 Resultado do Tesouro & 41.028 & 21.496 & $(19.532)$ \\
5.2 Resultado da Previdència & $(9.752)$ & $(12.056)$ & $(2.304)$ \\
5.3 Resultado do Bacen & $(89)$ & $(110)$ & $(21)$ \\
\hline
\end{tabular}

Fonte: STN/MF

Retomando o conceito de Resultado Primário, anteriormente explanado, constata-se que este implica diretamente no endividamento e na necessidade de financiamento do Estado.

A Carta de Conjuntura do IPEA (2009) aborda duas características da dívida líquida do setor público em relação ao PIB: primeiramente, seu valor apresenta uma série histórica decrescente. Em 2003 correspondia a 58,7\% do PIB, já em 2006 caiu para $44 \%$, chegando ao fim de 2008 no patamar de $35,8 \%$ do PIB.

A outra característica é que dificilmente a dívida pública sofre com crises cambiais em função da dívida interna (que supera em muito a dívida externa) não ser indexada ao dólar ${ }^{27}$. As tendências citadas podem ser percebidas pelo gráfico da próxima página:

${ }^{27}$ Entre 1999 e 2002, a composição da dívida era radicalmente diferente e as finanças públicas eram vulneráveis a abalos provocados por ataques especulativos, crises cambias e fortes desvalorizações do real 


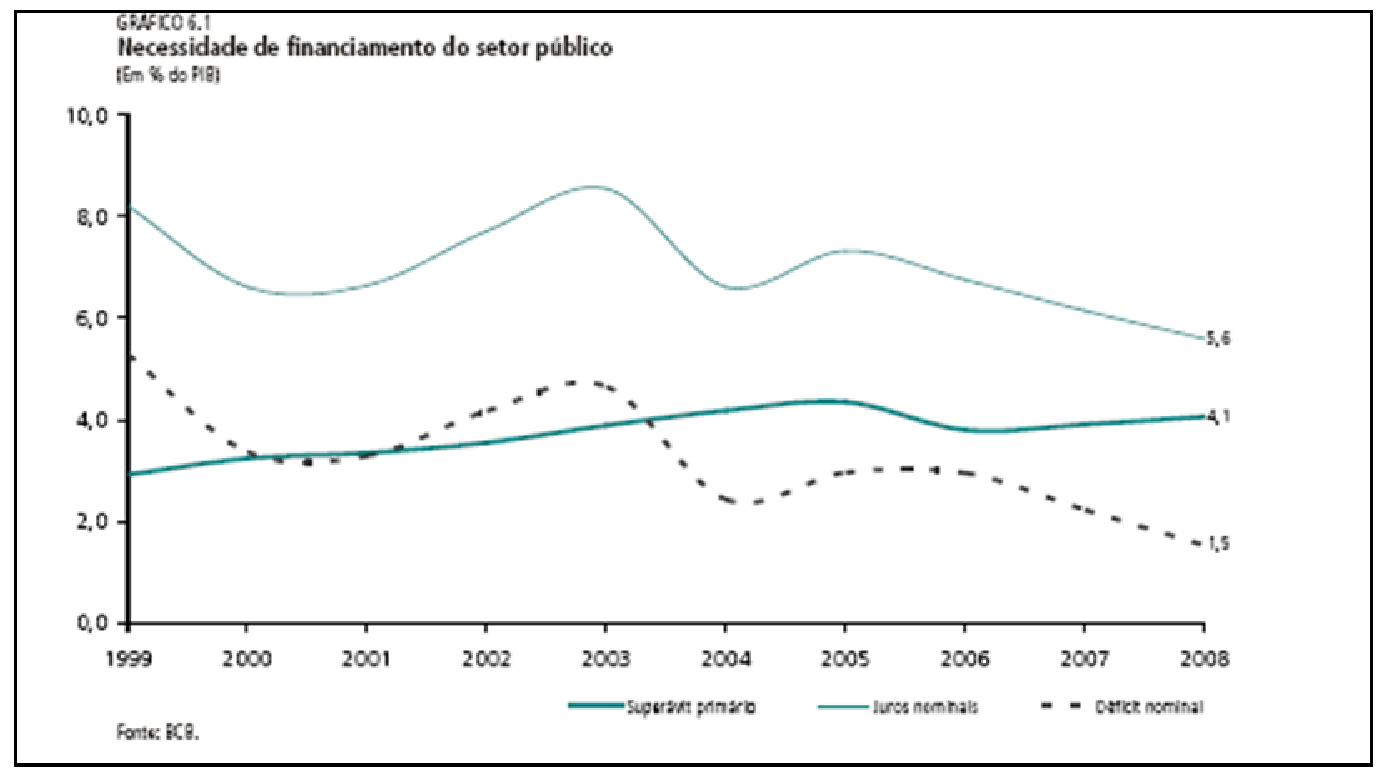

Ilustração 20: Necessidade de Financiamento do Setor Público Fonte: BCB. Elaboração: IPEA (2009a)

Os fatores que condicionaram a redução da dívida líquida do setor público consolidado ao longo de 2008, ainda seguindo o entendimento do IPEA (2009a), foram, principalmente, o superávit primário elevado o crescimento, acompanhado crescimento do PIB e o ajuste cambial do período, este impactando nos números negativos da dívida externa.

Adentrando 2009, A dívida líquida do setor público entrou numa trajetória de alta, passando de $37,1 \%$ do PIB, em fevereiro de 2009 , para $37,6 \%$, em março.

A expectativa do mercado BCB (2009), boletim Focus de 12 de junho, é de que a dívida líquida chegue a 39, 1\% do PIB, aumento que se pode explicar, apesar da queda dos juros reais, pela expectativa mediana do mercado de crescimento negativo do PIB e da redução do superávit primário para $2,5 \%$.

Analisando os números consolidados do $1^{\circ}$ quadrimestre, COFF (2009), a Dívida Pública Federal (DPF), diminuiu 0,85\%, em relação ao estoque inicial, de $R \$$ $1.407,6$ bilhões para $\mathrm{R} \$ 1.395,7$ bilhões. A variação da DPF decorreu principalmente dos resgates líquidos de $R \$ 46,9$ bilhões da dívida mobiliária interna (DPMFi), de $R \$ 4,5$ bilhões da dívida externa (DPFe), e da apropriação negativa da variação cambial sobre esta última dívida ( $R \$ 9,5$ bilhões). Os dados citados podem ser melhor compreendidos observando a Tabela 12, a seguir: 
Tabela 12: Dívida Pública Federal (DPF) de Responsabilidade do Tesouro Nacional em Mercado.

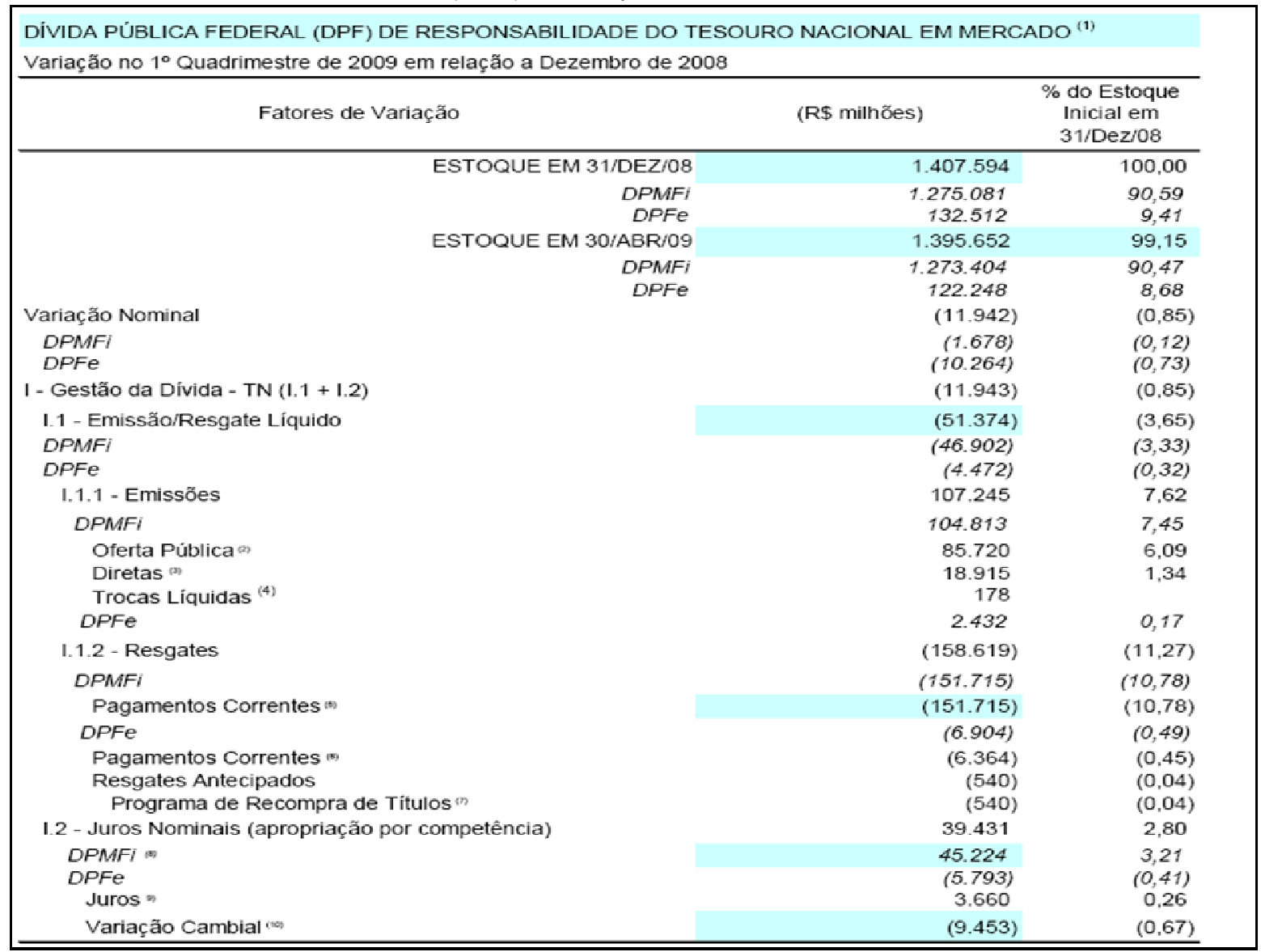

(1) Inclui dívida contratual.

(2) Emissões de títulos de DPMFi que ocorrem principalmente por meio de leilões ou por meio do Programa Tesouro Direto, excluindo títulos da Dívida Securitizada e TDA. Não incluem as operações de troca/permuta de títulos nem os cancelamentos.

(3) Referem-se às emissões para fins específicos autorizados em lei (e.g. permuta de títulos da DPMFi com bancos), às emissões sem contrapartida financeira para atender aos Programas de Reforma Agrária (TDA), Proex, FIES e FCVS e aos cancelamentos de títulos, exceto os recebidos em leilões de troca. \% do Estoque Inicial em 31/Dez/08 (R \$ milhões)

(4) Diferença entre emissões (preço de mercado) realizadas por troca e os títulos aceitos (preço da curva-estoque).

(5) Pagamentos de amortizações e juros da DPMFi.

(6) Pagamentos de amortizações e juros da DPFe mobiliária e contratual.

(7) Programa de recompra da DPFe iniciado em janeiro de 2006.

(8) Contempla a atualização monetária do principal e a apropriação de juros reais da DPMFi.

(9) Saldo dos juros apurados por competência no período.

(10) Demonstra o efeito da apreciação/depreciação do dólar e demais moedas subjacentes à DPFe em relação ao real.

Fonte: STN (2009). Elaboração: COFF (2009).

Para finalizar a discussão quanto à dívida pública, é muito enriquecedor observar os pontos de vista destoantes dos entrevistados Paulo Henrique Feijó (STN), numa linha mais conservadora:

Nesse ponto eu acho que o governo está usando as armas que tem até um determinado limite, que é o limite da responsabilidade fiscal. Afinal de contas, as decisões que geram déficits para gerações futuras, nós sabemos que no Brasil a conta chega em algum momento. Chega sobre forma de 
inflação, chega sobre forma de carga tributária elevada. Portanto, a decisão do presente tem seqüelas no futuro e por isso que ela tem que estar sempre amparada na busca de um equilíbrio fiscal. [...]Agora, O governo talvez tenha que restringir um pouco dessas "benesses" para poder garantir a meta do resultado primário no final do ano. Minimamente garantir a execução do próprio orçamento, pois com a queda da arrecadação o que tem sido comum então é o contingenciamento conforme a regra que a própria LRF estabelece. Se minha meta primária não vai ser cumprida porque não alcançou a receita prevista, o próprio governante é obrigado a tomar essa medida, portanto o nível de ferramenta ou de armas que o governo vai utilizar, vai depender muito desses aspectos fiscais o que pode ser acrescentado também vai ser limitado em função disso. O governo tem todo um arsenal mas definitivamente não vai poder utiliza-los todos de uma vez só. Tem que saber qual a arma que ele tem pra utilizar nesse momento e às vezes ser um tiro certeiro em determinado setor ,e não uma grande solução geral e irrestrita. (FEIJÓ, 2009, apêndice E)

\section{E Milko Matijascic (IPEA), mais empreendedor:}

Por exemplo, o que nós colocamos como reação à crise, hoje não atinge nem $2 \%$ do PIB, ou seja, de novos gastos que saem do orçamento público, de comprometimento público para ativar a crise. A China, por exemplo, já se comprometeu com quase $17 \%$ do seu PIB, então, é uma reação muito maior. Os Estados Unidos se comprometeram com algo como 8 a $9 \%$. A própria Alemanha, muito criticada, já fez mais do que o dobro da gente. A Argentina, nosso vizinho, fez mais do que o dobro da gente, e nós temos condições fiscais boas, nós temos ai um enorme superávit primário, uma taxa de juros ainda alta que pode ser reduzida.

[...] Eu acho que desse ponto de vista, é o investimento, é o fazer, é digamos assim, é o fazer obras, é o modificar o espaço público, é o incentivo a política pública, e nesse tipo de coisa nós ainda estamos devagar, também é do ponto de vista do apoio das nossas empresas. A Índia, por exemplo, fez pacotes grandes em termos de créditos para suas grandes empresas para que elas saiam mundo afora comprando outras empresas e reforcem a posição competitiva de seu país. A Rússia está pretendendo fazer a mesma coisa e nós estamos muito passivos. Nós estamos apoiando muito pouco esse tipo de coisa, é o momento que nós podíamos ir lá nos Estados Unidos, por exemplo, no Vale do Silício, onde estão as grandes empresas de tecnologia do mundo, comprar uma empresa média daquelas, custaria uma bagatela para as nossas grandes empresas, e aprender como essa gente trabalha com tecnologia, como é o dia a dia.

[...]eu acho que as nossas reações são muito tímidas, e eu acho que está todo mundo muito feliz, achando que as reações não foram péssimas, mas de qualquer maneira, se não foram péssimas e é bom que não tenham sido, e que os programas tenham operado de maneira correta, nós temos que ser mais agressivos nessa etapa 2, que é uma etapa de investimento, de gastos, de realização de obras mais produtivas, para que a gente tenha condições melhores de sair dessa crise numa posição melhor do que entramos, numa posição relativa melhor, com mais poder de barganha internacional, e eu acho que isso ainda está devagar demais na nossa sociedade. (MATIJASCIC, 2009, apêndice F) 


\subsubsection{Contingenciamento}

A Lei de Responsabilidade Fiscal (LRF) prevê em seu artigo 9o a possibilidade de contingenciamento do orçamento:

Art. $9^{\circ}$. Se verificado, ao final de um bimestre, que a realização da receita poderá não comportar o cumprimento das metas de resultado primário ou nominal estabelecidas no Anexo de Metas Fiscais, os Poderes e o Ministério Público promoverão, por ato próprio e nos montantes necessários, nos trinta dias subseqüentes, limitação de empenho e movimentação financeira, segundo os critérios fixados pela lei de diretrizes orçamentárias. (Lei Complementar $n^{\circ} 101$ de 04 de maio de 2000 , caput)

Diante de todos os fatores conjunturais apresentados durante este trabalho, não é de se admirar que o artigo acima citado fosse posto em prática.

No final de janeiro de 2009, o Poder Executivo editou o Decreto $n^{\circ} 6.752 / 09$, limitando até o mês de março, em $R \$ 37,3$ bilhões, a movimentação e empenho de suas despesas autorizadas na LOA.

Recorrendo novamente à Nota Técnica da COFF (2009), tem-se que o contingenciamento inicial foi modificado pelo Decreto $n^{\circ} 6.808 / 09$ para $R \$ 21.267,5$ milhões, sendo reestimado, em seguida, pelo Decreto $n^{\circ} 6.867 / 09$ em decorrência da redução da meta primária para os orçamentos fiscal e da seguridade em $R \$ 23,7$ bilhões implicando numa redução de $R \$ 9.147,2$ milhões da margem de contingenciamento, resultando no total de $R \$ 12.120,3$ milhões, conforme detalha a Tabela 13, na página seguinte: 
Tabela 13: Orçamentos Fiscal e da Seguridade 2009 : Determinantes do Contingenciamento de Despesas do Executivo nos Decretos de Programação Financeira.

\begin{tabular}{|c|c|c|c|c|c|}
\hline \multicolumn{6}{|l|}{ ORÇAMENTOS FISCAL E DA SEGURIDADE SOCIAL, 2009} \\
\hline \multicolumn{6}{|c|}{ Determinantes do Contigenciamento de Despesas do Executivo nos Decretos de Programação Financeira ${ }^{(1)}$} \\
\hline Item de Variação em Relação a Lei & RS milhões & $\%$ & R\$ milhões & $\%$ & $\begin{array}{c}\text { Diferença } \\
\text { RS milhões }\end{array}$ \\
\hline $\begin{array}{r}\text { Receitas Administradas } \\
\text { Receitas Não Administradas } \\
\text { Arrecadação do INSS }\end{array}$ & $\begin{array}{r}(37.377,5) \\
(4.066,3) \\
(6.895,5)\end{array}$ & $\begin{array}{r}(175,7) \\
(19,1) \\
(32,4)\end{array}$ & $\begin{array}{r}(49.317,6) \\
(3.866,3) \\
(6.895,5)\end{array}$ & $\begin{array}{r}(406,9) \\
(31,9) \\
(56,9)\end{array}$ & $\begin{array}{c}(11,940,1) \\
200,0 \\
-\end{array}$ \\
\hline Operações com Ativos & 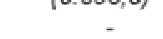 & - & - & - & - \\
\hline Transferências a Estados e Municipios & $15.928,9$ & 74,9 & $18.333,5$ & 151,3 & $2.404,6$ \\
\hline Beneficios Previdenciários & $(7.650,8)$ & $(36,0)$ & $(5.574,7)$ & $(46,0)$ & $2.076,1$ \\
\hline Beneficios Assistenciais Vinculados ao Minimo & - & - & $1.498,4$ & 12,4 & $1.498,4$ \\
\hline Créditos Extraordinánios & $3.000,0$ & 14,1 & $3.300,0$ & 27,2 & 300,0 \\
\hline Subsidios e subvençöes & $(5.285,5)$ & $(24,9)$ & $(5.285,5)$ & $(43,6)$ & - \\
\hline Auxilio Financeiro aos Municipios & - & $=$ & $1.000,0$ & 8,3 & $1.000,0$ \\
\hline Outras Despesas Obrigatónas & $1.245,4$ & 5,9 & $1.583,7$ & 13,1 & 338,2 \\
\hline Contingenciamento & $21.267,5$ & 100,0 & $12.120,3$ & 100,0 & $(9.147,2)$ \\
\hline
\end{tabular}

Fonte: COFF (2009)

Os valores totais do orçamento e do contingenciamento do Decreto 6.808/09 divididos por Órgãos/Unidades Orçamentárias do Poder Executivo encontra-se no Anexo 2, ao final deste trabalho.

A entrevistada Maria Liz Roarelli salientou as dificuldades relacionadas ao contingenciamento, sob o ponto de vista do Poder Legislativo:

A grande crítica que o congresso faz ao contingenciamento, historicamente, é que ele altera a distribuição que o congresso fez. Então, o executivo pode contingenciar, porque ele até é obrigado pela LRF, se ele não acredita que aquela receita será suficiente. $O$ problema é que quando ele vai distribuir o pouco que restou, ele distribui em proporções por ministérios que não foi a mesma proporção que o Congresso aprovou. Assim, ele distorce o que foi aprovado pelo Congresso. Muitas vezes eles cotingenciam ou deixam até de pagar suas emendas, mas o orçamento como um todo precisa ser revisto. O papel do Congresso no orçamento precisa ser revisto porque existem muitas despesas que já são determinadas legalmente. Então, a margem de manobra que sobra para o congresso é muito pequena e às vezes não há capacidade técnica para aprovar um projeto já bem estruturado e acompanhar esse projeto, tem que ter uma influência do Congresso talvez nas linhas gerais, quais as áreas que quer priorizar.

[...] O processo na interação legislativo-executivo tem que ser melhorado, ele não pode ficar só no âmbito das emendas.

[...] Na parte da despesa, ainda existem muitas falhas, o papel do legislativo ainda está pequeno, ainda está tímido, ainda está muito voltado só para acréscimo de emenda, pouco para cancelamento das despesas. Então, essas coisas ainda têm que ser melhoradas. (ROARELLI, 2009, apêndice C) 
É relevante comentar que o $\S 1^{\circ}$ do artigo $9^{\circ}$ da LRF estabelece que, no caso de restabelecimento da receita prevista, haverá recomposição dos valores anteriormente limitados. Sendo assim, a diminuição do contingenciamento representa mais recursos disponíveis para o atendimento das políticas prioritárias do Governo.

Por derradeiro, a fim de encerrar o atual capítulo, cita-se a opinião mais recente de Matias-Pereira, em artigo publicado em junho de 2009:

Assim, torna-se recomendável, diante de um contexto de incertezas, que o governo brasileiro adote medidas criativas na condução da política econômica, em especial das políticas fiscal, monetária e cambial, na busca de reduzir as vulnerabilidades externas e explorar as vantagens comparativas do país, apoiando-se no mercado interno e na geração de estímulos à produção de alimentos e de energia. Essas políticas irão permitir que o Brasil enfrente de maneira adequada nos próximos anos, os seus amplos e complexos problemas socioeconômicos, políticos e ambientais, que estão se agravando com os impactos decorrentes da crise financeira e econômica mundial. (MATIAS-PEREIRA, 2009b, p.4) 


\section{CONCLUSÃO E CONSIDERAÇÕES FINAIS}

A proposta apresentada nesse trabalho envolve a análise de um contexto econômico internacional diante de uma crise financeira que se intensificou a partir do segundo semestre de 2008. Conforme visto, esse processo já vinha sendo construído há algum tempo sem que nenhuma ação governamental efetiva fosse tomada visando uma mudança de rumo. De fato, uma crença inquestionável nas leis naturais de mercado que levam a economia para o equilíbrio vem sendo apontada como principal responsável pela crise que teve início nos Estados Unidos da América e se alastrou por todo o mundo.

No campo teórico, e de forma inevitável, as ideáis de Keynes no que se refere ao papel regulador do Estado no sistema econômico reaparecem na forma de uma crítica generalizada não apenas à "Mão Invisível", mas ao próprio processo de globalização.

Como uma resposta imediata à crise, os governos de diversos países (inclusive o Brasil) passaram a adotar uma postura de "afrouxamento" nas contas públicas dentro do melhor receituário keynesiano de uma política fiscal expansionista. No caso brasileiro, a revisão das metas de superávit primário para o triênio 2009/2011 não deixam dúvidas de que a adoção de uma política anticíclica apresenta-se como uma alternativa de curto prazo.

Essa atitude do Governo Federal brasileiro diante da crise passa necessariamente pela utilização do orçamento público como ferramenta estabilizadora e de manutenção do nível de renda e emprego na economia demonstrando que o mesmo tem sido efetivamente considerado tanto no entendimento das implicações involuntárias da crise na economia e finanças públicas do país, quanto quais medidas estão sendo adotadas visando uma reação. Inclusive proporcionando uma comparação entre os orçamentos e indicadores de diferentes países, permitindo a compreensão do posicionamento estratégico do Brasil em relação aos demais. Nesse caso, a opção por uma política de incentivos fiscais e de redução de impostos, associada ao aumento nos gastos correntes e de capital em nível federal visam reduzir os efeitos da recessão internacional sobre o PIB. 
Observa-se que o governo brasileiro possui atualmente certa flexibilidade ao que tange possíveis correções em seu planejamento, que num cenário de incertezas torna-se fundamental na medida em abre um espaço para manobras e a adoção de políticas criativas de incentivo à retomada do dinamismo econômico.

A partir das análises apresentadas, percebe-se que o orçamento público não apenas reflete os efeitos da crise econômica de forma imediata, mas também apresenta-se como instrumento capaz de amortecer os impactos da recessão no curto prazo.

Essas conclusões evidenciam a capacidade que o setor público possui para a correção de rumos na economia em nível macroeconômico através de ferramental próprio. No entanto, é forçoso culpar o sistema de mercado pelos desajustes estruturais que levam às crises e recessões. É necessário lembrar que setor governamental também está inserido nesse sistema, interferindo de forma direta e indireta na produção, na oferta monetária, no crédito e na renda nacional.

Portanto, percebe-se que governo e setor privado são duas faces de uma mesma moeda chamada mercado e somente um trabalho articulado e harmônico entre esses dois setores poderá levar à melhor utilização dos recursos disponíveis e ao máximo bem-estar social.

\subsection{Considerações para trabalhos futuros}

O tema pesquisado envolve um complexo emaranhado de variáveis que sofrem influências entre si. Cada tema abordado aqui pode ser encarado de forma específica, merecendo um rico aprofundamento. O tratamento dado a este trabalho apresenta apenas a ponta de um iceberg, ou seja, o orçamento público federal em seus grandes números, num momento pontual. E o que vem depois? Como essas recentes medidas impactarão na economia brasileira futuramente? Representarão os esforços mais eficientes ou equivocados? Os parâmetros e procedimentos do orçamento público continuarão os mesmos após tantas críticas e modificações? Torna-se-á mais flexível ou mais preciso? E como foram afetados os investimentos públicos? Qual foi o impacto nos orçamentos dos grandes estados brasileiros? $\bigcirc$ Brasil conseguirá retomar o dinamismo do primeiro semestre de $2008 ?$

Espera-se que o fim deste trabalho represente o começo de diversos outros. 


\section{REFERÊNCIAS}

BALEEIRO, A. Uma introdução à ciência das finanças. 15.ed. Rio de Janeiro: Forense, 1968.

BANCO MUNDIAL. Global monitoring report 2009: a development emergency. Washington DC:2009. Disponível em:<http://web.worldbank.org/WBSITE/

EXTERNAL/EXTDEC/EXT GLOBALMONITOR /EXTGLOMONREP2009/0,,menuPK: 5924413 pagePK:64168427 piPK:64168435 theSitePK:5924405,00.html > Acesso em 05 Jun. 2009.

BCB. Banco Central do Brasil. Focus - Relatório de Mercado. Brasília: abril, 2009. Disponível em: <http://www4.bcb.gov.br/pec/GCI/PORT/readout/R20090424.pdf > Acesso em14 Mai. 2009a.

BCB. Banco Central do Brasil. Relatório de Estabilidade Financeira. Brasília: abril, 2009b. Disponível em: <http://www4.bcb.gov.br/pec/GCl/PORT/readout/R20090424. pdf > Acesso em 14 Mai 2009.

BRASIL. Constituição (1988). Constituição da República Federativa do Brasil. Senado Federal, Brasília, 1988.

BRASIL. Projeto de lei orçamentária n. 38 de 2008. Brasília: Congresso Nacional, 2008.

2000.

. Lei Complementar n. 101 de 04 Mai. 2000. Brasília: Congresso Nacional, . Lei n. 4.320 de 17 Mar. 1964. Brasília: Congresso Nacional, 1964.

. Lei Orçamentária n. 11.897 de 30 Dez. 2008. Brasília: Congresso Nacional, 2008.

CMO. Comissão Mista de Planos, Orçamentos Públicos e Fiscalização. Relatório geral: projeto de lei orçamentária n. 38 de 2008. Brasília: Congresso Nacional do Brasil, 2008. Disponível em:<http://www2.camara.gov.br/orcamentobrasil/ orcamentouniao/loa/loa2009/ciclos/parecercmo/parcmo.html> Acesso em18 Fev. 2009

COFF. Consultoria de Orçamento e Fiscalização Financeira. Nota técnica $\mathbf{n}^{\circ}$ 10/2009: cumprimento meta quadrimestres I e II - avaliação 2009. Câmara dos Deputados. Brasília, junho de 2009. Disponível em: <http://www2.camara.gov.br/ orcamentobrasil/orcamentouniao/estudos/2009/NT\%2010-2009.pdf>. Acesso em 16 Jun. 2009

Relatório da atualização das estimativas da receita. Congresso Nacional do Brasil, 2008a. Disponível em: <http://www2.camara.gov.br/orcamentobrasil/ 
orcamentouniao/loa/loa2009/ciclos/parecercmo/parcmo.html> Acesso em $18 \mathrm{Fev}$. 2009.

DIAMOND, J. Do orçamento por programas para o orçamento por desempenho: o desafio para economias de mercado emergentes. In GIACOMONI, J.; PAGNUSSAT, J. L. (org). Planejamento e Orçamento Governamental. Coletânea volume 2. Brasília: ENAP, 2006.

FEIJÓ, P.; MEDEIROS, M.; ALBUQUERQUE, C. Gestão de finanças públicas: fundamentos e práticas de planejamento, orçamento e administração financeira com responsabilidade fiscal. 2 ed. Brasília, 2008.

FERRARI FILHO, F.; de PAULA, L. F.. Pode 'ela' acontecer de novo?. Dossiê da Crise, Associação Keynesiana Brasileira: Porto Alegre: novembro 2008. Disponível em : <http://www.ppge.ufrgs.br/akb> Acesso em 16 Mar. 2009.

FMI. Fundo Mundial Internacional. Avant-propos conjoint pour les perspectivas de l'economie mondiale et le rapport sur la stabilité financiérè dans le monde. Washington, abril 2009. Disponível em:< http://www.imf.org/external/french /pubs/ft/weo/2009/01/pdf/textf.pdf> Acessado em 10 Jun. 2009.

FMI. Fundo Mundial Internacional. Perspectives de l'économie mondiale. Washington, abril 2009. Disponível em:<http://www.imf.org/external/french /pubs/ft/weo/2009/01/pdf/sumf.pdf> Acesso em 10 Jun.2009.

GIACOMONI, J. Orçamento público. 14 ed. São Paulo: Atlas, 2009.

GIL, A. C. Como elaborar projetos de pesquisa. 4 ed. São Paulo: Atlas, 2007.

IBGE. Instituto Brasileiro de Geografia e Estatística. Indicadores conjunturais. Rio de Janeiro, 2009. Disponível em:<http://www.ibge.gov.br/home/mapa_site /mapa_site.php\#economia> Acesso em 25 Abr. 2009.

IEDI. Instituto de Estudo para o Desenvolvimento Industrial. Entendendo a Crise Subprime e suas Repercussões na Economia Mundial. Parte 1. Carta IEDI n.300. São Paulo, 2008. Disponível em: <http://www.iedi.org.br/media/20080222-01.gif> Acesso em 03 Jun. 2009

IPEA. Instituto de Pesquisa Econômica Aplicada. Carta de Conjuntura. n.5. Brasília, dezembro de 2008. Disponível em: < http://www.ipea.gov.br/default.jsp > Acesso em 23 Mar. 2009.

IPEA. Instituto de Pesquisa Econômica Aplicada. Carta de Conjuntura. n.6. Brasília, março de 2009a. Disponível em: < http://www.ipea.gov.br/default.jsp > Acesso em : 10 Mai. 2009a.

IPEA. Instituto de Pesquisa Econômica Aplicada. Crise Internacional: impactos sobre o emprego no Brasil e o debate para a constituição de uma nova ordem global. Comunicado à presidência n.21. Brasília, abril de 2009b. Disponível em: <http://www.ipea.gov.br/default.jsp > Acesso em : 10 Mai. 2009. 
KEYNES, J. M. A teoria geral do emprego, do juro e da moeda. 1 ed. São Paulo: Editora Atlas, 1982.

LACERDA, A crise internacional e o Brasil. Conferência Nacional de Política

Externa e Política Internacional, Rio de Janeiro, 2009.

MARCONI, M. A.; LAKATOS, E. M. Fundamentos de metodologia científica. 6 ed. São Paulo: Editora Atlas, 2007.

MARQUES, N. A ortodoxia se rende mais uma vez à heterodoxia econômica.

Revista de Cunjuntura - CRE DF, Brasília, n. 36, 2008.

MATIAS-PEREIRA, J. Manual de metodologia da pesquisa científica. São Paulo: Atlas, 2007.

. A economia brasileira frente à crise financeira e econômica mundial. en Observatorio de la Economía Latinoamericana, Número 116, 2009b. Disponível em: <http://www.eumed.net/cursecon/ecolat/br/ >.Acesso em 15 Jun. 2009.

Curso de administração pública: foco nas instituições e ações governamentais. São Paulo: Atlas, 2008. 2009a.

.Finanças públicas: a política orçamentária no brasil. 4 ed. São Paulo: Atlas,

MINSKY, H. P. Can 'it' happen again? Essays on instability \& finance. Armonk, New York: M.E.Sharpe, 1982.

MOTA, J. R. S. T. Dimensão mundial da crise econômica e sua natureza.

Câmara dos Deputados, Consultoria Legislativa. Nota técnica. Brasília, 2009.

Disponível em: <http://www2.camara.gov.br/internet/publicacoes/estnottec> Acesso em 15 Abr. 2009.

MPOG. Ministério do Planejamento, Orçamento e Gestão. Histórico das atividades orçamentárias. MPOG. Brasília, 2009. Disponível

em:<http://www.planejamento.gov.br/secretaria. $a s p ? c a t=51 \& s u b=128 \& \mathrm{sec}=8>$

Acesso em 20 Mai. 2009.

MUSGRAVE, R.; MUSGRAVE, P. Finanças públicas: teoria e prática. São Paulo: Campus, 1980.

NORTH, D.. Institutions, institutional change and economic performance. Cambridge University Press: Cambridge, 1990.

ROESCH, S. Projetos de estágio e de pesquisa em administração: guia para estágios, trabalhos de conclusão, dissertações e estudos de caso. São Paulo: Atlas, 2006.

SANCHES, O. M. O ciclo orçamentário: uma reavaliação à luz da constituição de 1988. Revista de Administração Pública, Rio de Janeiro. v. 15, n. 3 , outubro/dezembro 1993. 
SENADO FEDERAL. Boletim Informativo. n. 4 de 1 a 31 de maio. Consultoria Legislativa: Comissão de Acompanhamento da Crise Financeira e da Empregabilidade. Brasília, 2009. Disponível em: <http://www.senado.gov.br/ comunica/comissao_crise/Boletim.asp > Acesso em 08 Jun. 2009.

SILVA, E. C. A crise financeira mundial sob a perspectiva da OMC, do FMI e do Banco Mundial. Nota técnica. Consultoria Legislativa da Câmara dos Deputados. Brasília, 2009. Disponível em: <http://www2.camara.gov.br/publicacoes/ estnottec/copy4_of_notas tecnicas > Acesso em 10 Abr. 2009.

SILVERWOOD, K. O. A evolução recente da política ambiental no brasil: uma análise a partir do plano plurianual de 2000/2003. Dissertação (Mestrado em Ciência Política) UnB. Brasília, 2005.

SIMONSEN, M. H.;CYSNE, R. P. Macroeconomia. 2 ed.São Paulo: Atlas, 1995.

TAVARES, M. C. A crise financeira atual. Paper Itamaraty. Brasília, 2009. Disponível em: http://www.funag.gov.br/eventos/eventos-funag2009/ ?searchterm= maria\%20da\%20conceição> Acesso em 01 Jun.2009.

TEIXEIRA, M. P. Impacto macroeconômico da crise atual. Nota técnica:

Consultoria Legislativa da Câmara dos Deputados. Brasília, 2009. Disponível em: < http://www2.camara.gov.br/publicacoes/estnottec/copy4_of_notas técnicas > Acesso em 10 Abr. 2009.

VERGARA, S. C. Projetos e relatórios de pesquisa em administração. São Paulo: Atlas, 1998.

WILDAVSKY, A. The new politics of the budgetary process. Boston: Little Brown and Company, 1992.

WILDAVSKY, A; CAIDEN, N. Planning and budgeting in poor countries:

comparative studies in behavioral sciences. New York: Jonh Wiley and Sons, 1974. 


\section{APÊNDICES}

\subsection{Apêndice A - Entrevista Estruturada}

Duração prevista: 15 minutos

Na sua opinião:

1. Quais as conseqüências esperadas da crise financeiro-econômica global para o país e seus reflexos sobre o orçamento público federal brasileiro?

2. De que forma o Governo Federal poderá utilizar o Orçamento Público visando atenuar os efeitos da atual crise financeira e econômica sobre a nossa economia?

3. As modificações realizadas até agora no orçamento público federal brasileiro são condizentes com as reais necessidades de incentivo neste momento de crise? Por quê? O que poderia ser acrescentado? 


\subsection{Apêndice B - TERMO DE CONSENTIMENTO LIVRE E ESCLARECIDO}

Eu,

residente e

domiciliado(a) nascido(a) em

$1 \ldots$ _ ocupante da função

concordo de livre e espontânea vontade em conceder entrevista presencial respondendo a 3 questões previamente elaboradas acerca dos impactos da crise no orçamento público federal brasileiro, elaboradas pela aluna do curso de Administração da Universidade de Brasília, Paula Ramalho Nóbrega Sant'Ana, matrícula 05/37357, para compor sua pesquisa de monografia.

Ciente do caráter acadêmico do referido trabalho, autorizo a divulgação do conteúdo de minha entrevista, devidamente referenciado, bem como de meu nome, cargo e instituição. Assino o presente documento em duas vias de igual teor e forma, ficando uma em minha posse.

Brasília, de junho de 2009.

(assinatura do(a) entrevistado(a))

Paula Ramalho Nóbrega Sant'Ana 


\subsection{Apêndice C - Entrevista: Cristiano Ordones Portugal - Assessor Econômico do Ministério do Orçamento, Planejamento e Gestão.}

1) Com relação à questão da crise, era de se esperar já que no último trimestre de 2008 começamos a sofrer uma forte desaceleração da economia. Isso começou a ter reflexo em toda a estrutura econômica, e do ponto de vista da questão fiscal, teve um impacto direto na arrecadação, até muito mais forte do que na questão dos estados e dos municípios. Essa receita começou a cair, IPI, Imposto de Renda... Começaram a ter quedas, e quedas nominais irreais em relação ao ano anterior. Então, a gente que vinha, nos últimos anos, até então, desde 2007, início de 2008 tendo recordes na questão de superávit primário, questão fiscal, dívida, mantendo aquela trajetória de quedas acelerando a proporção do PIB, começou a ter um impacto direto nos indicadores fiscais.

Além disso, o que o governo então procurou fazer? "Bom, tá tendo queda na arrecadação e eu vou ter que tomar algumas medidas pra poder reverter esse quadro de desaceleração econômica." Consequentemente retomar a questão da volta dos bons indicadores fiscais, retomar a arrecadação, o crescimento da arrecadação ia voltar. Em decorrência disso, então, o que o governo fez? Ele reforçou políticas que ele já vinha adotando, no intuito de promover o crescimento econômico. Então, por exemplo, já estavam sendo adotadas medidas de desonerações tributárias com o aumento da receita onde o governo começou a entrar mais forte, sobretudo no IPI, então tivemos desonerações no IPI automóveis, na linha branca de eletrodomésticos. Além disso, ele atacou também pelo lado da despesa, então ampliou a política de investimento, quer dizer, infra-estrutura. A política de gasto social, foi ampliada. A questão do prazo do seguro desemprego, políticas na área social foram reforçadas, e se observarmos, tivemos também a política de habitação. Então, na área do gasto, a gente tentou ampliar, fazer uma política anticíclica, juntamente com a questão de exonerações tributárias no intuito de fazer uma política anticíclica retomando o crescimento econômico, tendo de volta uma arrecadação maior, e por aí vai. Por conta da necessidade de tomar essas políticas, o governo mexeu na meta fiscal. Tínhamos uma meta de 3,80\% do PIB que foi reduzida para $2,5 \%$. Por que isso? O 2,5\% do PIB para o setor público como 
um todo, não estou falando só do governo central, isso foi revisto para dar suporte a essa política anticíclica. Estamos tendo problemas de queda de arrecadação, ainda fazendo desoneração tributária e ainda tendo que aumentar gastos.

2) A questão chave é essa, a arrecadação está caindo com a desaceleração, mas o governo tem que fazer alguma coisa, no sentido de fazer uma política anticíclica para a retomada de crescimento, então ele ampliou as medidas que já estavam sendo tomadas, como a desoneração tributária, aumentou os gastos na parte de investimento e infra-estrutura, classe social e a política habitacional, e consequentemente ele teve que reduzir a meta fiscal principalmente de 2009, do setor público como um todo que passou de 3,80 para $2,5 \%$, e isso seria uma política pontual já que a partir de 2010 a gente vai voltar a meta normal. Qual é a diferença? A gente vai retirar do cálculo a Petrobrás, até por que já não tem mais sentido. A Petrobrás é uma empresa que o país necessita pra retomada do crescimento com os investimentos de infra-estrutura, então, penalizar uma empresa que dá lucro, que é importante mandando ela cortar gastos pra suprir as outras, então a gente acha melhor tirar a Petrobrás e deixar que ela faça o investimento dela. Por outro lado, mantivemos nosso esforço fiscal, vai pra $3,3 \%$, tirando o $0,5 \%$ do PIB, que era o esforço que a Petrobrás tinha que fazer, que é um esforço grande, meio por cento de PIB não é pouca coisa, então a gente não pode penalizar a Petrobrás com meio por cento do PIB, e vamos tornar essa outra parte do setor público de forma que vá fazer o $3,3 \%$.

3) Com relação ao cenário que estamos passando, o governo tinha que fazer alguma coisa, uma política pra tentar refazer a retomada do crescimento econômico, então, dentro do que se espera de uma política fiscal. Eu acho que a política fiscal tem que ir por esse caminho, direcionar a questão do gasto de maneira eficiente, torná-la da maneira mais eficiente possível, vamos melhorar a infra-estrutura do país, vamos tentar minimizar a perda de renda, que é conseqüência da queda do PIB pra população e vamos tentar diminuir a carga tributária pra o setor produtivo poder investir. Então, dentro desse âmbito é importante o agora, não pode perder o foco da questão do ajuste fiscal. Tem que resguardar uma meta e manter um compromisso de que como a gente está no olho do furacão, esse ano e o ano que 
vem espera-se estar melhor, então esse ano a gente mantém a meta, tem que sinalizar que temos uma meta, mas que ano que vem espera-se que as coisas voltem ao normal e a gente continue fazendo o esforço fiscal que a gente precisa. Então a questão é direcionar o gasto pro lugar certo e manter a meta fiscal, cortar aquilo que a gente pode cortar e manter o gasto naqueles pontos chaves.

Ainda tem uma reforma tributária que precisa andar. Mexer nessa reforma agora acho que não vai acontecer. Não só desonerar, mas deixar o sistema menos complexo por que isso pode envolver perda de arrecadação, então a gente já está perdendo arrecadação, eu não sei se isso realmente vai pra frente, é um ponto importante. Outro ponto importante é o controle da despesa de pessoal. Temos um projeto de lei lá no congresso que precisa também andar pra frente. É aquilo que eu falei, fazer política anticíclica é importante, mas a gente não pode deixar que haja descontrole nas despesas e ter mais eficiência na arrecadação. O que está sendo feito é a melhor coisa do mundo? Também não é por ai, é um passo que a gente tem que dar de cada vez, a desoneração tributária eu acho que é uma coisa muito importante que a gente não estava agüentando mais a carga tributária, estava muito alta, então, isso ai é um passo importante. A questão tanto do lado da receita quanto do lado da despesa ainda tem um passo longo a caminhar. Do lado da despesa falta ainda criar uma rédia mais forte, colocar o controle sobre a despesa de pessoal, apesar de que essa despesa vinha caindo em proporção do PIB nos últimos anos. Agora que houve um processo de renegociação com várias carreiras, ela retomou o crescimento. Acho que é nesse momento que a gente pode lançar mão de um projeto de lei para controlar o gasto. Na medida em que vamos reorganizando o patamar que as carreiras devem receber a gente já pode negociar uma questão de limite para esse tipo de gasto até pra não ficar naquela coisa de que agora a gente não vai dar um aumento porque a gente sabe que se der um aumento aqui, a outra carreira vai querer, a outra vai querer e não tem limite pra gente poder negociar "ó, pra você agora não dá porque a gente tem aquele limite" então isso ai é importante também, mas é importante andar pra frente. 


\subsection{Apêndice D - Entrevista: Maria Liz de Medeiros Roarelli - Consultora Legislativa do Senado Federal - Área de Orçamento}

1) A principal conseqüência financeira para o país, foi um estancamento imediato dos financiamentos externos, é uma diminuição aos poucos dos mercados internacionais pra exportação, no caso o Brasil sendo o exportador, teve uma queda imediata no PIB já no primeiro trimestre da crise, a partir de outubro de 2008. Essa queda foi também por conta de expectativas de que haveria carência de recursos externos que afetaria o país, mas na verdade não era pra ter afetado tanto, porque foi mais uma crise de credibilidade, de insegurança, que fez com que os investidores parassem com medo que, de repente, os seus fornecedores não tivessem financiamentos eles não iriam fornecer. É como um efeito dominó. Mas o Brasil não estava em condições tão ruins quanto as outras economias que foram diretamente afetadas pela crise, como Estados Unidos, Europa. O Brasil está ainda com o modelo voltado para o consumo interno, pra demanda doméstica e a parte das exportações não tem um peso tão grande no crescimento econômico porque ele foi todo voltado pro mercado doméstico, e o crédito doméstico representa $80 \%$ do total, só $20 \%$ do crédito é externo. Então, $20 \%$ é muita coisa? É, mas se for observar o total, ainda tinha $80 \%$ para poder manobrar até a economia restaurar seus níveis anteriores de credibilidade, e tanto teve que o Brasil conseguiu. O governo está emprestando mais, abrindo mais linhas de crédito no BNDES e na Caixa Econômica, pra manter os níveis de investimento privado e de consumo também. Manteve a política do salário mínimo que já vinha sendo mantida, com valores altos, porque se teve reajuste de salários mínimos. Já a partir de fevereiro, manteve essa política e conseguiu fazer uma desoneração e adiar pagamentos de impostos. O Governo Brasileiro conseguiu escapar da crise até porque muitos bancos que ele conseguia as linhas de crédito eram públicos e o Brasil não teve que privatizar bancos porque ele pôde usar os bancos públicos que ele já tinha como o BNDES e a Caixa Econômica como bancos de fomento. Agora do ponto de vista do orçamento público federal brasileiro, teve a conseqüência imediata da queda das receitas, a queda da arrecadação. Isso não afetou o orçamento de 2008 porque já vinha com uma bolha de arrecadação muito alta, que acabou o ano cumprindo sua meta de superávit e 
ainda sobrando dinheiro. Em 2009 é que foi mais afetado pela crise porque começou o ano com a receita já em queda. No primeiro trimestre reduziu $R \$ 3$ bilhões da receita primária total e havia uma queda na receita em termos reais também. Então, teve um impacto imediato sobre arrecadação por causa da queda do PIB, além disso, o governo com as medidas de desonerações, as medidas provisórias, ele estimou só pro ano de 2009 uma queda na arrecadação de $R$ \$ 20 bilhões, na verdade é uma estimativa de desoneração, não é uma estimativa de queda da arrecadação, porque se você não estivesse desonerado, é possível que sua arrecadação caísse mais. Então, essa desoneração é justamente pra manter níveis compatíveis de crescimento econômico pra ter uma arrecadação razoável, não tão em queda assim. Então, esses $\mathrm{R} \$ 20$ bilhões é a estimativa da desoneração que 0 Governo promoveu com essas medidas anticíclicas que ele teve que tomar pra poder combater a crise e sair da crise. Depois o Governo teve que tomar a medida de reduzir a meta de superávit primário pra 2009. Essa também foi uma medida que ele teve que tomar pra combater a crise. Então os reflexos da crise sobre o orçamento público eles estão se dando do lado da receita por causa de um chamatório entre desonerações e queda do PIB e do lado da despesa que pode até ter um aumento porque o Governo está investindo mais pra poder manter o crescimento econômico, a conseqüência final disso é uma redução do superávit primário.

2) Por ser proativo, o Governo fez a política de desonerações, então ele reduziu as alíquotas da Cofins, do IOF, da Cite Combustíveis, do imposto de renda retido na fonte (que teve uma alteração na tabela), e também algumas postergações de pagamentos. Fora isso o Governo, ele próprio, reduziu a meta de superávit primário, conforme já tinha dito, e ele também resolveu retirar a Petrobrás da meta, porque ela tradicionalmente não é considerado investimento como o déficit porque eles têm retorno. Existem algumas teorias que defendem que não é bom ter empresas produtivas nas metas de superávit primário, então foi retirado. Para 2009 reduziu de $3,8 \%$ pra 2,5\% e além disso você ainda pode usar meio por cento do referente ao PPI, meio por cento do PIB. Então o Projeto Piloto de Investimento, você ainda pode usar isso e nesse caso o Governo Central passaria de 2,15\% pra $1,4 \%$ seu superávit e as estatais com a retirada da Petrobrás passariam de $0,70 \%$ a 
$0,20 \%$. Assim, ele deixou uma margem bem mais flexível para aumentar investimentos e fez as desonerações também e a recuperação pra 2010 ela pode ser um resultado dessas medidas que foram tomadas agora já em 2009

Acho que são, acho que ter feito a política de desoneração tributária foi positiva, tanto é que não caiu tanto, agora foi $0,8 \%$ de queda muita gente estava esperando mais até $2,3 \%$ de queda do PIB trimestral e isso tudo foi por causa das políticas que foram tomadas de segurar o crédito, de segurar as políticas, de desonerar as empresas, os excessos de tributos e o resultado foi que o PIB não caiu tanto, caiu 0,8\% podia ter caído mais. Outra coisa foi ter tirado a Petrobrás do calculo e ainda por cima poder gastar mais meio por cento em investimento é tudo que o país está precisando: investimento em infra-estrutura. Existe também uma inflexibilidade dos gastos com custeio, no caso de pessoal que aumentou muito. Praticamente todo o aumento das despesas, foi nisso. Até o momento, a maior parte do aumento das previsões para esse ano foi de despesa de pessoal e custeio, a de investimento foi menos, mas só que se observa um crescimento cada vez maior, mais acelerado dos investimentos e existe também uma "autorização", vamos dizer assim, de você gastar mais com investimentos. Então tem que esperar ter a maturação e também esperar resolver alguns gargalos que estão impedindo os investimentos de serem realizados. Atualmente, no caso dos investimentos públicos, o principal gargalo é a falta de, vamos dizer assim, organização e até de administração. O país ficou muito tempo sem o planejamento. Agora que se precisou mais do planejamento faltou instrumentos para conduzir esses investimentos, porque ninguém conseguia medir direito as falhas, por exemplo, desde a falta de pessoal, de engenheiro capacitado pra acompanhar as obras, tudo isso pra tocar um projeto e fora isso tem [ruído] do TCU também que conseguiu detectar muitas irregularidades, muitas obras paradas. Esse gargalo ainda falta ser resolvido, porque tem a parte legal e a parte, vamos dizer assim, técnica. Precisa arrumar uma fórmula para evitar que uma obra parada seja mais cara do que é tocar a obra, de outra forma, resolver a parte legal e continuar tocando a obra tem que evitar esses gargalos. 
3) Dentro do orçamento o que pode ser resolvido é dentro da LDO que nós estamos aprovando agora. É colocar alguns artigos que destravem um pouco a paralisação de obras. Mas isso está sendo estudado ainda. Mas é uma coisa que pode ser acrescentada, porque a falha assim existe. Muitas regras e muita legalidade e a obra fica parada com uma parte já pronta. Isso tem que ser resolvido. Esses entraves têm que ser resolvidos. Existem também algumas críticas sobre as legislações que às vezes têm permitido "a inversão de fases". Têm permitido que empresas que tenham pouca qualificação por um processo mais ágil de licitação, ela consiga a obra por cobrar menos, mas ela não dá conta porque ela não tem capacidade técnica. Isso foi aprovado recentemente, mas existem muitas criticas porque os especialistas dizem que essa não foi uma boa regra, a inversão de fases, porque ela permite que empresas com pouca capacidade técnica ganhem uma licitação e não consiga terminar a obra. Então esses critérios de licitações ele tem que ser revistos de uma maneira geral e poder tornar as obras mais rápidas, mais ágil o processo, mas também mais eficiente, eficaz que chegue ao objetivo, que era traçado inicialmente não que pare no meio.

Quanto ao contingenciamento, fizeram um contingenciamento de $R \$ 23$ bilhões e depois reduziram o superávit e até sobrou dinheiro para fazer ajustes nas despesas discricionárias. Mas, a grande crítica que o congresso faz ao contingenciamento, historicamente, é que ele altera a distribuição que o congresso fez. Então, o executivo pode contingenciar, porque ele até é obrigado pela LRF, se ele não acredita que aquela receita será suficiente. O problema é que quando ele vai distribuir o pouco que restou ele distribui em proporções por ministérios que não foi a mesma proporção que o Congresso aprovou. Assim, ele distorce o que foi aprovado pelo Congresso, muitas vezes eles cotingenciam ou deixam até de pagar suas emendas, mas o orçamento como um todo precisa ser revisto. O papel do Congresso no orçamento precisa ser revisto porque existem muitas despesas que já são determinadas legalmente. Então, a margem de manobra que sobra para o congresso é muito pequena e às vezes não há capacidade técnica para aprovar um projeto já bem estruturado e acompanhar esse projeto, tem que ter uma influência do Congresso talvez nas linhas gerais, quais as áreas que quer priorizar, porque assim, às vezes as emendas se perdem na execução praticamente elas não são executadas porque elas não são prioritárias pro executivo. Elas acabam deixando de 
ser obrigatórias. O papel do Congresso, assim quando o orçamento chega aqui, ele tem que ser revisto. Durante o processo, ainda no executivo, muitos parlamentares podem participar, requerendo os recursos pras suas regiões, isso antes do orçamento chegar aqui. Mas de uma maneira geral, o processo na interação legislativo-executivo tem que ser melhorado, ele não pode ficar só no âmbito das emendas. Agora já evoluiu bastante, por exemplo, aqui no legislativo a gente já teve uma influência sobre as estimativas de receitas que antes diziam que era só para aumentar as emendas, e nós conseguimos reverter essa opinião, pois as estimativas de receitas para mais que fizemos, praticamente todas ocorreram na prática. Nós alteramos parâmetros, atualizamos parâmetros. Essas mudanças mostram que o congresso ficou mais ativo na no seu papel dentro do processo. Entretanto, na parte da despesa, ainda existem muitas falhas, o papel do legislativo ainda está pequeno, ainda está tímido, ainda está muito voltado só para acréscimo de emenda, pouco para cancelamento das despesas. Então essas coisas ainda têm que ser melhoradas. 


\subsection{Apêndice E - Entrevista - Paulo Henrique Feijó - Coordenador Geral de Contabilidade da Secretaria do Tesouro Nacional.}

1) As conseqüências a gente já está vendo pelo que a própria imprensa noticia no mundo. O problema de emprego, conseqüente impacto na geração de renda e, em termo de governo, a conseqüência que diminuindo a atividade econômica, diminui a arrecadação do governo. Então acho que de maneira geral tem o impacto "positivo", que seria o que nós estamos vendo na linha de juros. $\mathrm{Na}$ medida que os juros caem então o impacto sobre a dívida do país diminui o pagamento de juros pelo país. O próprio impacto também já reflete crise e confiança no país, que são os efeitos sobre a política cambial, ou seja, a questão do dólar, onde o investidor está encontrando no Brasil, mesmo com todo o impacto da crise, um porto seguro. Acho que ajudou muito o país a ser um país de grau de investimento. No ano passado as agências de rating acabaram avaliando o país como esse porto seguro. Os números macroeconômicos são favoráveis ao Brasil, fruto, logicamente, de todo ordenamento fiscal de 26 anos atrás. O Brasil pedia ajuda ao fundo monetário numa situação super difícil, uma completa desordem das finanças públicas. E fruto de vários governos desde o governo Sarney, o próprio Fernando Collor, Fernando Henrique e a manutenção disso pelo governo Lula, o Brasil conseguiu sair então de um nível de um país que não tinha a menor credibilidade na área fiscal para ser um país de grau de investimos com práticas internacionalmente reconhecidas. Acho que podemos dizer que no momento em que a crise pegou o país, ele estava justamente num programa de gastos do governo com incentivo de crescimento. Encontrou o carro a uma determinada velocidade, o país dentro da velocidade, deu o primeiro freio de arrumação nesse grande carro e agora ele está tentando retomar a sua velocidade a partir de alguns incentivos pelo próprio governo. O orçamento acaba sofrendo reflexos por se tratar de receitas e despesas. Então, tem impacto nas receitas de governo, que também ontem foi comprovado que pelo sétimo mês seguido a arrecadação não caiu mesmo com a desoneração que o próprio governo fez em decorrência da própria atividade econômica ter diminuído no país. Do lado da despesa você tem um forte impacto do aumento das despesas correntes, pelo menos em termos nominais pelo governo, 
que de um lado podemos dizer está, até certo ponto, ajudando a economia, está colocando mais dinheiro. Mas, por outro lado, cria um flanco na área fiscal a partir do momento que você quer calibrar o superávit primário para manter sua dívida sobre controle, então é lógico que a crise impacta diretamente o orçamento e isto está refletido nos diversos contingenciamentos que o governo vem fazendo ao longo do ano.

2) Tem várias formas na verdade. Tanto pelo orçamento, como margeando o orçamento. O principal, no primeiro momento, a crise foi uma crise de crédito, então não necessariamente o governo tinha que gastar, tinha que arrumar dinheiro pra irrigar a economia e permitir, então, que o mercado atuasse com maior crédito. Entregar dinheiro pro sistema financeiro e pra vários agentes da economia de modo a permitir, a elevação do nível de credito no país, isso não necessariamente passa pelo orçamento. Por exemplo, indiretamente o governo às vezes com uma medida mais de regulamentação como o CODEFAT, conselho do FAT, liberar mais recursos para empréstimos ao BNDES e outras fontes baratas de recursos que o governo busca, normalmente tributárias, e entregar para o setor, para os bancos oficiais principalmente o BNDES, pra empréstimo. E aí, acho que essa foi a primeira linha de atuação do governo na parte do orçamento. Como a atividade econômica caiu, o governo tinha que incentivar. Ele pode incentivar por dois lados, ou o próprio governo gastando mais e aí tem o programa de aceleração do crescimento, da continuidade dos investimentos. Do outro lado a desoneração de tributos como a redução de IPI e tudo isso, às vezes tem impacto colaterais, no caso da desoneração das receitas, vemos aí que além de perder uma parte das receitas mesmo aumentando a atividade econômica do setor automobilístico, ou mesmo da construção civil, mais recentemente a questão das empresas que trabalham com a linha branca (refrigeradores, fogões), isso reduz IPI e ao reduzir IPI reduz repasses para os estados e municípios. Na outra ponta, o governo tem que socorrer os estados e municípios pela diminuição de sua arrecadação e isso ensejou alguns bilhões a serem repassados da União para os estados e municípios. Então, o governo federal acaba tendo um papel de tentar equalizar os vários lados, tanto o lado do cidadão quanto o lado dos entes federativos. Estamos numa federação. A crise impacta fortemente os estados também pela questão do ICMS, assim como o IPI é um dos mais afetados, e é a principal receita dos estados. Daí a linha de 
crédito também aberta no BNDES para os estados. É importante salutar que somos um país que tem uma Lei de Responsabilidade Fiscal com alguns limites para 0 endividamento. O governo acaba tendo que usar todas as suas armas dentro de algumas limitações estabelecidas pela própria legislação, pela própria Lei de Responsabilidade Fiscal. O orçamento como principal instrumento de política fiscal acaba sendo um elemento primordial na atuação do governo. Mas a crise não é um problema a ser solucionado só com recursos do orçamento, muitas vezes é a não receita, a isenção de alguns tributos, para fazer com que setor privado alavanque a economia. Então não devemos achar que a solução está toda no orçamento publico, toda no governo, gastando mais ou deixando [ruído] mas sim criando mecanismo de incentivo ao setor privado a ajudar, juntamente com o governo, a amenizar os impactos da crise.

3) Como já eu comentei antes. Na verdade não dá pra dizer se são suficientes até porque tem um limite também [ruído] do governo. Por mais que alguém dissesse que o governo resolve a crise injetando mais 200 bilhões de gasto publico, tem o efeito físico sobre a divida, tem o efeito físico sobre outros parâmetros macroeconômicos, que devem ser alegados. Portanto a economia são vasos comunicantes em que quando eu mexo numa variável todas as outras se movimentam e ao se movimentarem tem impactos negativos ou positivos sobre o próprio governo. Portanto a decisão do governo não é uma decisão totalmente livre. É uma decisão que tem reflexo às vezes sobre ele próprio, que se diga agora a dicotomia do governo em encerrar a isenção ou incentivo na indústria automobilística vis a vis ter que manter o equilíbrio fiscal. Então, a questão do equilíbrio fiscal para 2010, amenizado pelo governo, reduz a meta de resultado primário dentro de uma política anticíclica, que se diz então quando o país estiver numa fase difícil, diminui o [resultado] primário, quando tiver na abonança aumenta o [resultado] primário, essa seria a política anticíclica. Nesse ponto eu acho que o governo está usando as armas que tem até um determinado limite, que é o limite da responsabilidade fiscal. Afinal de contas, as decisões que geram déficits para gerações futuras, nós sabemos que no Brasil a conta chega em algum momento. Chega sobre forma de inflação, chega sobre forma de carga tributária elevada. Portanto, a decisão do presente tem seqüelas no futuro e por isso que ela tem que estar sempre amparada na busca de um equilíbrio fiscal. Acho que com um pouco da retomada da atividade 
econômica, o que poderia ser acrescentado deve ser avaliado de forma pontual em cada setor, não uma regra geral. Agora, O governo talvez tenha que restringir um pouco dessas "benesses" para poder garantir a meta do resultado primário no final do ano. Minimamente garantir a execução do próprio orçamento, pois com a queda da arrecadação o que tem sido comum então é o contingenciamento conforme a regra que a própria LRF estabelece. Se minha meta primária não vai ser cumprida porque não alcançou a receita prevista, o próprio governante é obrigado a tomar essa medida, portanto o nível de ferramenta ou de armas que o governo vai utilizar, vai depender muito desses aspectos fiscais o que pode ser acrescentado também vai ser limitado em função disso. O governo tem todo um arsenal mas definitivamente não vai poder utiliza-los todos de uma vez só. Tem que saber qual a arma que ele tem pra utilizar nesse momento e às vezes ser um tiro certeiro em determinado setor ,e não uma grande solução geral e irrestrita. 


\subsection{Apêndice F - Entrevista: Milko Matijascic - Chefe da Assessoria Técnica da Presidência do Instituto de Pesquisa Econômica Aplicada (IPEA) e Economista-Chefe do grupo de estudos da crise do IPEA.}

1) Naturalmente uma crise dessas é uma crise que vai apresentar o que já está apresentando que é uma retração do nível de atividades da economia. Essa retração já se apresentou no quarto trimestre de 2008 e no primeiro trimestre desse ano, e provavelmente, se não houver uma reação, o segundo trimestre terá um nível de atividades ainda muito claudicante, ou pelo menos muito restrito do ponto de vista do seu desempenho. Ainda possivelmente será um desempenho pior do que o do segundo trimestre do ano passado. Mas considerando a envergadura da crise internacional, considerando o enorme volume de dificuldades envolvidas e principalmente o enorme descolamento da massa financeira em relação aos bens e ativos disponíveis e para transação da economia, a economia brasileira pode-se dizer que está se saindo relativamente bem. Mas isso não elimina o fato de que se vai ter retração econômica, e essa retração econômica, do ponto de vista do orçamento, vai causar dificuldades. Os dados de hoje estão mostrando que é a primeira vez desde 1995, talvez até antes, que você já vê uma redução da carga tributária. Retraiu a atividade. O último trimestre do ano sofreu um baque muito forte. Então, o que aconteceu? Menos pessoas comprando, menos pessoas transacionando na economia, mais gente perdendo emprego... Isso imediatamente, do ponto de vista do orçamento, significa que você vai estar arrecadando menos recursos. E do ponto de vista da despesa orçamentária, você tem outra dificuldade que é muito séria. Como o Estado de uma certa maneira tem o papel dentro de uma economia capitalista moderna de fazer o efeito contracíclico, então uma série de despesas não podem ser comprimidas ou reduzidas por que as receitas se reduziram. Então, por exemplo, as despesas previdenciárias são rigidas, as despesas com funcionalismo público são rígidas, muitas despesas de custeio são relativamente rígidas, e as despesas de investimento que já são baixas no Brasil, essas sim podem ser comprimidas, mas não devem ser comprimidas nesse momento. Então, acho que desse ponto de vista, o orçamento público federal se ressente grandemente da queda de atividade, e um ponto a enfatizar é que a queda 
de atividade internacional, principalmente em um momento em que o Brasil vinha importando bastante, também é importante do ponto de vista do orçamento porque tudo que o Brasil exporta, de uma certa maneira, se não na sua totalidade, mas na sua quase totalidade, é desonerado de impostos, mas em compensação, o que você importa é taxado e muitas vezes, sobretaxado. Então, o que acontece, no momento em que você importa menos, que talvez seja bom pra indústria nacional, mas no ponto de vista do erário público é complicado por que está recebendo menos recursos. São questões que estão sendo relacionadas ao orçamento público federal relativas a carga tributária que afeta a tributação como um todo por que tem menos gente trabalhando, menos gente consumindo, menos atividade, o nível de atividades em geral cai, e ao mesmo tempo você tem que sustentar certas despesas que são rígidas, e de preferência, inclusive, gerar mais despesas para incentivar a demanda efetiva, e esse incentivo a demanda efetiva tem um reflexo importante pelo lado das despesas para o governo federal.

2) O que os governos podem fazer de um modo geral é procurar relançar a economia através de uma política consciente de gastos. Então, o que faz? O governo transfere dinheiro para a economia, esse dinheiro é gasto com consumo, investimentos e uma série de motivos, esses gastos por sua vez vão gerar novos gastos e acionar o que se chama de um efeito multiplicador da renda, então esse é um mecanismo Keynesiano Clássico, tradicional. O governo brasileiro inclusive está procurando lançar mão disso. Assim, o que seria importante? Muitas vezes em um primeiro momento, e eu acho que agora estamos chegando em um momento que de um modo geral, e eu nem sei afirmar isso com 100\% de segurança, mas nós estamos ultrapassando uma primeira fase da crise, que essa primeira fase é uma fase em que você estava "apagando incêndios", de um modo geral procurando segurar as instituições, evitando que grandes empresas quebrem, procurando reforçar o poder de compra de consumidores, fortalecendo o capital de giro de corporações, então, nesse ponto de vista, esse primeiro momento é importante porque é a quebra de algumas grandes empresas ou de alguns grandes bancos ou a redução muito radical do consumo leva a comportamentos pessimistas, muitas vezes caóticos do ponto de vista da desarticulação da economia. Mas, muitas vezes isso não é suficiente você pegar e transferir dinheiro ou dar incentivo e esperar que 
esse dinheiro seja bem gasto, ou seja, que o mercado possa agir. Então, que poderia ser feito através de incentivos, através de transferência direta para pessoas, de estímulo ao consumo, de estímulo ao investimento, de estímulo às condicionalidades econômicas. Nós estamos mais ou menos chegando ao fim desse movimento para chegar em um segundo movimento que do ponto de vista teórico é o Estado colocando a economia, o setor produtivo funcionar em marcha. Então, uma coisa é a transferência de renda, você tira de uma parte da sociedade e passa para outra, ou seja, "dos mais ricos para os mais pobres" como os programas previdenciários, bolsa família, etc, ou seja, dos mais pobres para os mais ricos arrancando dinheiro dos impostos da sociedade e colocando no banco para não quebrar o banco, colocando em uma grande empresa para não quebrar uma grande empresa, fundamentalmente é essa questão que está em jogo. Esse é o primeiro momento, de uma certa maneira, de preservar o estado de confiança positivo, ou, pelo menos, não muito negativo. A partir do segundo momento, agora, digamos que os efeitos poderosos e potenciais de gastos públicos de programas sociais de mecanismos para estimular o consumo eles vão mais ou menos atingir o seu limite, ou seja, as pessoas que queria comprar carro, uma redução dos imposto para comprar carro já exerceu mais ou menos os efeitos necessários. Quer dizer, quem não tem dinheiro para comprar carro, não é só porque é a $5 \%$ ou a $8 \%, 10 \%$ mais barato que vai comprar esse carro, uma pessoa que não tem dinheiro para investir também não vai investir ou então quem já está no bolsa família de uma certa maneira já está gastando, já tem seu orçamento comprometido não vai poder reincorporar novas parcelas da produção nacional, ou seja, você tem que partir para um segundo momento, e esse momento significa que é um momento que não é só a transferência para as famílias, mas fazer com que as empresas voltem a operar, aumentem seu nível de atividades e aumentando seu nível de atividades gere nova renda e nova demanda para realimentar o circuito inicial que é o da demanda que é da etapa um. O problema da etapa um é que o incentivo à demanda acaba, mas digamos assim, que é só a transferência para incentivar a demanda a atingir os seus limites e nesse segundo momento, que é de investimento e setores produtivos e esse tipo de questão quer dizer a utilização de recurso do orçamento para fazer obras públicas, para reforçar programas de investimento e para acompanhar o parque ou só os parques estaduais e municipais. Ele é necessário para fazer com que a economia adquira uma nova configuração, um novo tipo de atividade e que 
possa promover um nível de atividades maior e recuperar a economia ou criar novas possibilidades de crescimento sustentável de longo prazo.

3) Eu acredito que, como nós estavamos conversando, em relação a questão de número 2, é essa fase um que é de incentivo ao consumo, o governo brasileiro procurou fazer de maneira bastante bem feita, ele aumentou o número de pessoas que recebe bolsa família, ele facilitou o acesso ao seguro desemprego, facilitou as regras e permitiu que as pessoas permanecessem mais tempo no seguro desemprego, ele antecipou o reajuste do salário-mínimo e elevou o poder de compra do salário-mínimo, ele reduziu impostos para o setor automotivo e para o setor de linha branca de eletrodomésticos, ele procurou colocar mais dinheiro e reduzir os compulsórios nos bancos para facilitar o crédito, ou seja, quase tudo que ele podia fazer do ponto de vista da demanda efetiva, ele de uma certa maneira pelos instrumentos indiretos, ou seja, mudar determinadas regras e fazer determinadas coisas para incentivar o consumo, incentivar os investimentos, incentivar os empréstimos, ele fez. Poderia fazer mais nesse momento? Eu acredito que não possa fazer mais na via do que eu chamo de etapa 1, não pode se fazer muito mais do que isso, e possivelmente nem é desejável que se faça mais do que isso. O que ainda não está feito e não está claro é a etapa 2, essa etapa embora possa-se dizer que se tem o plano de investimentos que esteja em curso, que muita coisa esteja acontecendo no Brasil, que tem um grande volume de obras públicas, e esse tipo de coisa, o que é muito importante, evidentemente, os governos estaduais estão fazendo, os governos municipais também estão fazendo, eu diria que é tímido ainda. Por exemplo, o que nós colocamos como reação a crise, hoje não atinge nem $2 \%$ do PIB, ou seja, de novos gastos que saem do orçamento público, de comprometimento público para ativar a crise. A China, por exemplo, já se comprometeu com quase $17 \%$ do seu PIB, então, é uma reação muito maior. Os Estados Unidos se comprometeram com algo como 8 a 9\%. A própria Alemanha, muito criticada, já fez mais do que o dobro da gente. A Argentina, nosso vizinho, fez mais do que o dobro da gente, e nós temos condições fiscais boas, nós temos ai um enorme superávit primário, uma taxa de juros ainda alta que pode ser reduzida. Porque ela não é uma taxa só de incentivar o consumo, que é uma política típica da etapa 1, é também da etapa 2, porque ao mesmo tempo você deixa de gastar esse dinheiro com juros, 
você reduz despesas do orçamento com juros e pode liberar essas despesas para investimentos por exemplo. Então, eu acho que o investimento desse ponto de vista é o mais importante porque ao mesmo tempo em que você está transferindo renda para a economia, você está fazendo com que essa economia tenha um nível de atividades, ou seja, você passa a construir praça, casa, estrada, obra. Isso gera demanda de outros setores que por sua vez empregam mais e geram um efeito multiplicador, e um efeito multiplicador muito mais poderoso, que é do ponto de vista do consumo, mas também do ponto de vista da atividade econômica, dos investimentos, da atividade intermediária, da atividade meio para as atividades econômicas. Então, isso é muito importante. Então, desse ponto de vista eu acho que os nosso programas sociais são muito bons, dão muita garantia de renda, mas de uma certa maneira eles são muito passivos ainda. Faltam programas do tipo emprego garantido, por exemplo. O que significa isso? É um programa em que o governo emprega e paga por exemplo um salário-mínimo para cada trabalhador, mas esse trabalhador em contrapartida vai ter que estudar uma parte desse período, e vai ter que estar participando de obras públicas, vai estar construindo uma creche na sua comunidade, vai estar melhorando a praça, vai estar fazendo asfaltamento, vai estar fazendo obras relativas a saneamento básico, ou então, muitas vezes nos casos das mulheres, que trabalham menos com esse trabalho bruto, vão estar atendendo creches. O Brasil tem uma enorme carência de creches, as mães de famílias mais pobres muitas vezes não conseguem trabalhar e se juntar ao mercado de trabalho por que não têm com quem deixar seus filhos, e muitas vezes quando resolvem fazer isso... Olha o problema de criminalidade que está aí, muito sério. Talvez não aqui no Distrito Federal, mas nas grandes metrópoles internacionais como Rio e São Paulo. Eu acho que desse ponto de vista, é o investimento, é o fazer, é digamos assim, é o fazer obras, é o modificar o espaço público, é o incentivo a política pública, e nesse tipo de coisa nós ainda estamos devagar, também é do ponto de vista do apoio das nossas empresas. A Índia por exemplo, fez pacotes grandes em termos de créditos para suas grandes empresas para que elas saiam mundo afora comprando outras empresas e reforcem a posição competitiva de seu país. A Rússia está pretendendo fazer a mesma coisa e nós estamos muito passivos. Nós estamos apoiando muito pouco esse tipo de coisa, é o momento que nós podíamos ir lá nos Estados Unidos, por exemplo, no Vale do Silício, onde estão as grandes empresas de tecnologia do mundo, comprar uma empresa média 
daquelas, custaria uma bagatela para as nossas grandes empresas, e aprender como essa gente trabalha com tecnologia, como é o dia a dia. Vai ter um prejuízo? Esse prejuízo é mínimo, essas empresas podem arcar com isso, mas aprender a trabalhar com isso e aprender a trabalhar inovação na ponta, e trazer inovação para os nossos setores, porque a inovação é uma coisa que se aprende, você tem que criar uma cultura, e essas empresas já têm essa cultura, então isso é muito importante e nós estamos muito passivos. Nós ficamos pensando sempre nos nossos setores muito tradicionais. Então, eu diria que quanto a essa etapa $2 \mathrm{eu}$ estou muito preocupado, eu acho que as nossas reações são muito tímidas, e eu acho que está todo mundo muito feliz, achando que as reações não foram péssimas, mas de qualquer maneira, se não foram péssimas e é bom que não tenham sido, e que os programas tenham operado de maneira correta, nós temos que ser mais agressivos nessa etapa 2, que é uma etapa de investimento, de gastos, de realização de obras mais produtivas, para que a gente tenha condições melhores de sair dessa crise numa posição melhor do que entramos, numa posição relativa melhor, com mais poder de barganha internacional, e eu acho que isso ainda está devagar demais na nossa sociedade. 


\section{ANEXOS}

8.1 Anexo 01- Medidas de Desonerações Tributárias - 2009 
8.2 Anexo 02 - Contingenciamento do Decreto 6.808/09 divididos por Órgãos/Unidades Orçamentárias do Poder Executivo 